(n)

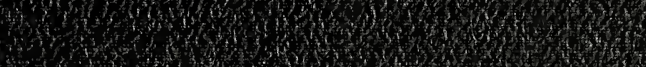

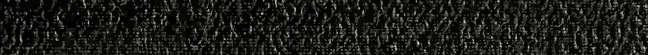
250. 19.5.

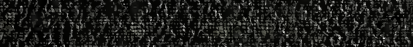
(1) (3)

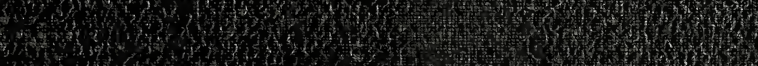

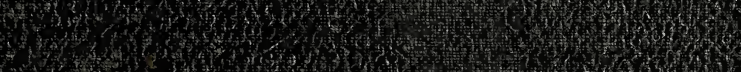
(5)

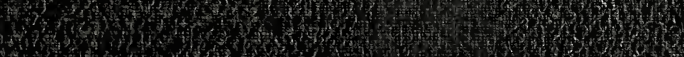
(3)

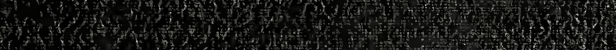
(3)

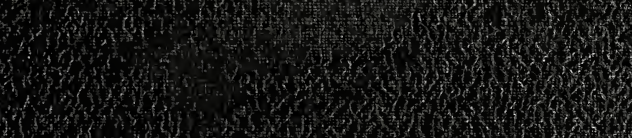
tis. n.t.

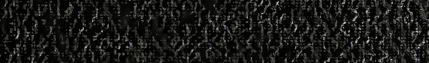

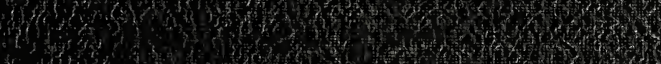

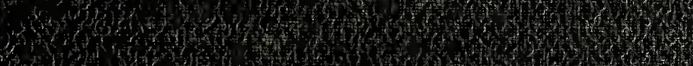
6rin

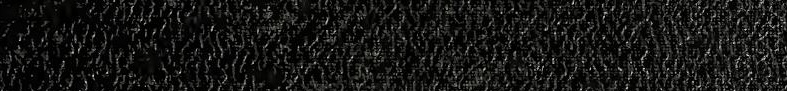

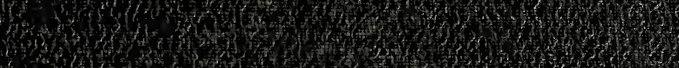

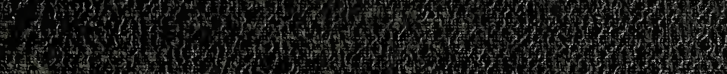

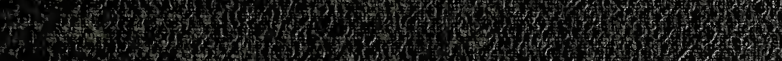

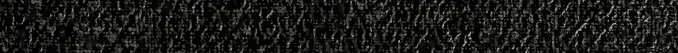
H.

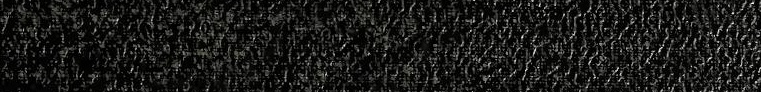

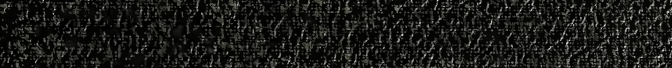

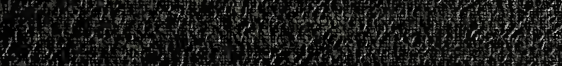

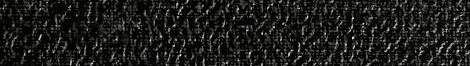

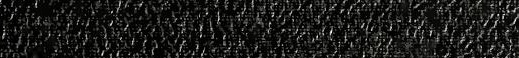
Whan

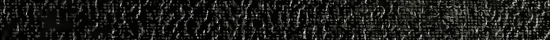

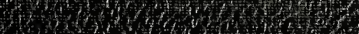

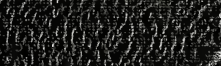


Smithsonian Institution Sibraries

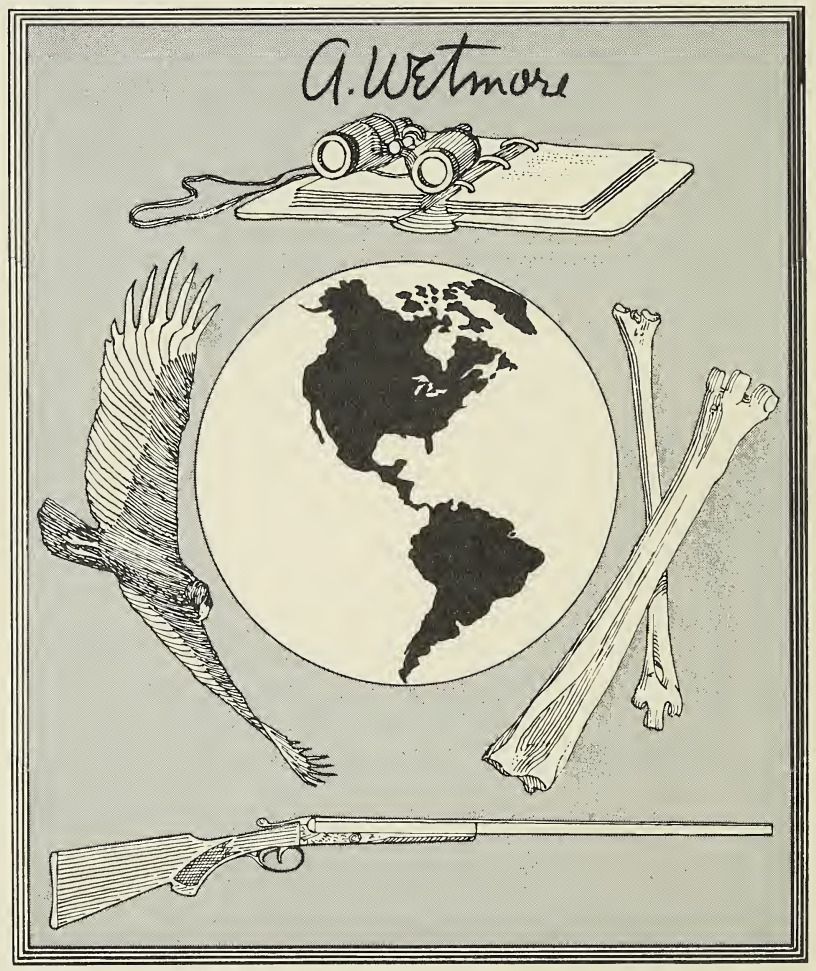

Alexander Wetmore

1946 SixthSecretary 1953

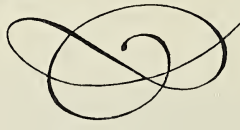


a.urtnou 

Alfred ruller

A. Urtmore 





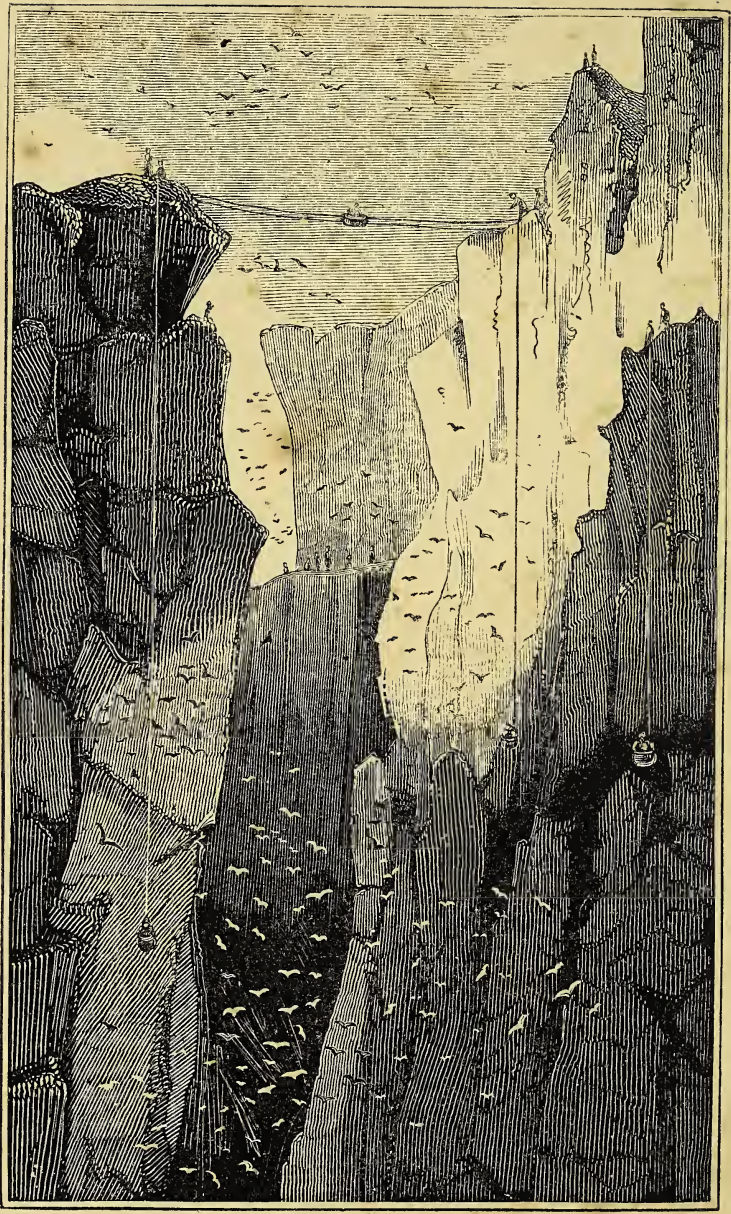

Sea-Fowl Catchins. 


\title{
FAMILIAR HISTORY
}

\author{
OF \\ B I R D S :
}

THEIR NATURE, HABITS,

AND INSTINCTS.

BY THE

REV. EDWARD STANLEY, M.A., F.L.S., \&c. \&c.

RECTOR OF ALDERLEY, CHESHIRE.

PUBLISHED UNDER THE DIRECTION OF THE COMMITTEE OF GENERAL LITERATURE AND EDUCATION, APPOINTED BY THE SOCIETY FOR PROMOTING CHRISTIAN KNOWLEDGE.

TWO VOLUMES, WITH ENGRAVINGS.

\section{VOLUME II.}

\section{LONDON :}

JOHN W. PARKER, WEST STRAND.

M.DCCC.XXXV. 



\section{VOLUME II.}

Chapter I. Passerine Order continued.-Conirostras; -Conical Beaks.-Orioles.-Starlings.-Habits of. -Finch Tribe.-Goldfinch.-Anecdotes of.-Nests rapidly completed.-Curious Nests in Africa.-Age of small Birds.-Canary Birds.-Trade in.-Bullfinches, Piping.-How trained.-Boldness of.-Affectionate and social Habits of.-Also of Linnets.Use of small Birds in destroying Insects .

Chapter II. Subulirostres; Awl-shaped Bills.-Manakins; curious Nests of. - Tomtits. - Wagtails. Redstarts.-Robins, \&c.-Migration of this Tribe. - Nightingales. - Whether they return to same Nests. - Ear for Music. - Night Singing-Birds.Planirostres; Flat-billed. - Swallow Tribe. - Whether occasionally Dormant; instances of.-Migration of. - Insects, number devoured by Swallows. Spiders, high Flights of.-Curious Nests of Swallows. - Courage of

Chapter III. Swallows' Nests continued.-Edible Nests, East Indies.-Goat-Suckers.-Mode of seizing Moths.-Cavern, with their Nests, described.Tenuirostres; Narrow-billed. - Nuthatch. - TreeCreeper. - Bee-Eater. - Hoopoe. - Kingfisher. Humming Birds.-Climbing Birds.-Cuneirostres; Wedge-billed.-Jacamar.-Anis.-Cuckoo.-Anecdotes and Habits of . . . . . 
Chapter IV. Cuneirostral continued.-WoodpeckerTame one.-Wryneck-Tongue of.-Levirostral; Light-billed.-Parrots. - Toucan. - GallinaceousPoultry Tribe. - Pigeons, American-Prodigious numbers of-Rapid flight-Employed as messengers -Mode of catching-Attachments of - Cocks.Pheasants-Courage of.-On breeding PheasantsBox for feeding-Prized by Ancients. - Turkies, Wild-Social habits of.-Partridges, tamed-Nests of-Various sorts of.-Quails-Immense flights of. -Bustards.-Ostrich-Nests of-Affection-Hunting-Strength of.-Cassowary and Emu . . . 80

Chapter V. Water-Birds.-Waders.-PressirostralNarrow-beaked. - Water-Hens - Anecdotes of Nests of. - Coots - Nests of.-Jacanas-Singular foot of. - Horned Screamers. - Rails. - OysterCatchers-Tamed.-Cultrirostra-Cutting-billed.Herons - Toothed-claw of-Voracity of. - Storks and Cranes - Migrations of - Respect paid to. Gigantic Crane-Particulars respecting.-Jabiru.Anastomus-Open-beaked.-Tantalus . . . 118

Chapter VI. Latirostral-Flat-beaked.-Boat-bill.Spoon-bill._Flamingo-Mode of feeding-Nest ofWatchful habits.-Tenuirostral, or LongirostralLong, slender-billed Birds.-Avoset.-Sand-Pipers. -Dotterel-Preservation of its Young.-Dunlin's Nest and Eggs.-Plover-Mode of catching.-Ibis -Mummies of - Why held sacred . . . . 144

Chapter VII. Palmipedes-Web-footed-Serrated or tooth-billed.-Geese-Flocks of-How managedPlucking. - Singular attachment-Sagacity-Courage of.-Tree Geese.-Swans-Muscular strength -Courage_-Black Swans.-Trade in Swan-quills . 169 
Chapter VIII. Duck Tribe-Management of-Chinese mode.-Wild Ducks building in trees-Affection of. -Eider Ducks-How caught.-Duck-Shooters.Danger attending Decoys . . . . . 188

Chapter IX. Pinnipedes-Swimming feet.-PelicanFable of drawing its blood explained-Mode of fishing.--Sea-Birds feeding on fish thrown up by Whales. - Cormorants - Voracity of - May be tamed Fierceness of.-Frigate-Bird.-Solan Goose-Lightness and buoyancy of-Nests.-Anhingas or Darters. 207

Chapter X. Longipennes-Long-winged. - Skimmers -Singular bill.-Terns, or Sea-Swallows-Anecdote of.-Gulls-Capacity for enduring cold-Voracious feeders-Breeding-places.-South Stack described. -Albatross-Roaming habits.-Tristan D'Acunha, Resort for breeding-Voracity.-Petrels-NestsFeed at night-Superstition of sailors respecting.Brevipennes - Short-winged. - Divers. - Crested Grebe-Great destroyer of fish. - Guillemots. Razor-Bills.-Puffins and Auks . . . . 222

Chapter XI. Penguins-Fin-winged.-King Penguin of the southern regions described-Breeding-places -Valuable for oil. —Sea-fowler's perilous occupation - Description of, in Shetland, St. Kilda, \&c.Singular escapes-Fatal accidents 



\section{DIRECTIONS FOR PLACING THE PLATES \\ IN VOLUME II.}

To face

Sea-Fowl Catching . . . . . . . . Title-page

The Emu, or Cassowary . . . . . . . . . 117

Jacana walking on Water-Plants . . . . . . 128

Oyster-Catchers . . . . . . . . . . . 130

Gigantic Crane . . . . . . . . . . . 140

Egyptian Plover and Crocodile . . . . . . 155

Cormorants . . . . . . . . . . . . . 213

Penguins . . . . . . . . . . . . . . 256

Perilous Leap of a Bird-Catcher . . . . . . 267 



\section{SKETCHES OF BIRDS.}

\section{CHAPTER I.}

PASSERINE ORDER CONTINUED.-CONIROSTRAS.-CONTCAL BEAKS.-ORIOLES.-STARLINGS.-HABITS OF.-FINCH TRIBE.-GOLDFINCH.-ANECDOTESOF.-NESTS RAPIDLY COMPLETED.-CURIOUS NESTS IN AFRICA, AGE OF SMALL BIRDS.-CANARY BIRDS.-TRADE IN. -BULLFINCHES, PIPING.-HOW TRAINED.-BOLDNESS OF.-AFFECTIONATE AND SOCIAL HABITS OF.-ALSO OF LINNETS.-USE OF SMALL BIRDS IN DESTROYING INSECTS.

\section{Table X. Order 2. Passerine.}

THere are seven genera of this tribe, of which four are foreign: it is the most numerous, perhaps, of all the divisions, including, as it does, that host of hardbilled birds, of infinite variety, from the Starling down to the Sparrow, which is scattered so widely over the face of the globe. To pretend to enumerate them in a work of this kind, would be impossible, and we shall therefore confine ourselves to a few anecdotes, illustrating the habits of some of those species which are most familiarly known. We have placed the Starling at the head of them, as being one of the connecting links between the Grackles and Thrush genera of the preceding table, and those of the present. There is one other bird, the Golden-Oriole, indeed, which is a more closely connecting link, and might, without impropriety, be voL. II. 
placed among the crenirostral birds, inasmuch as the point of its upper mandible is slightly notched; but we mention the Starling as the best known, the Oriole, or Golden-Thrush, being a bird of great rarity in this country, though, when once seen, it cannot fail of being recognised and remembered, the whole plumage, with the exception of the wings and tail, being of a bright orange or golden colour.

The Starling, although closely resembling the Thrush and Blackbird in some respects, differs from them essentially in others; and as its beak, on examination, will be found to be without a notch at its extremity, it may be decidedly placed amongst the conirostral tribe.

Of some birds it is difficult, from their retired habits, to give any clear and accurate account. Not so of our friend the Starling. When it suits his purpose, he comes fearlessly under our observation, and invites us to learn his history. For many and many a year have we watched him from month to month, with the exception of a certain season, when, for reasons best known to himself, he altogether disappears, and leaves us to wonder what is become of him.

Close before the window of our scene of observation, a well-mown short-grassed lawn is spread before him-it is his dining-room; there, in the spring, he is allowed to revel, but seldom molested, on the plentiful supply of worms, which he collects pretty much in the same manner as the Thrush, already described. Close at hand, within half a stone's throw, stands an ivy-mantled parish church, with its massy grey tower, from the turreted pinnacle of 
which, rises a tall flag-staff, crowned by its weathercock; under the eaves, and within the hollows and chinks of the masonry of this tower, are his nursery establishments. On the battlements, and projecting grotesque tracery of its Gothic ornaments, he retires to enjoy himself, looking down on the rural world below; while, at other times, a still more elevated party will crowd together on the letters of the weather-cock, or, accustomed to its motion, sociably twitter away their chattering song, as the vane creaks slowly round with every change of wind.

We will give a journal of our Starlings' liveses. At the close of January, one or two unconnected birds, now and then make their appearance on this weather-cock; at first but for a few minutes, as if, without an assignable reason, they had merely touched upon it as an inviting resting-place, in their unsettled course. In February, if the weather happens to be mild, the number of idlers may possibly now and then increase; but still the visit seems to be but the mere passing call of a few strangers, without a leading object. In March, however, about the first or second week, according to the state of the weather, things begin to assume a more bustling and serious appearance. Hitherto but one or two, or at most three or four, may have dropt in, as if to say, Here we are, the winter is past and gone, a happier season is at hand. But now the flights increase, the three and the four are multiplied to fourteen or sixteen, and the song becomes a little chorus, more loud and more joyous than before; and occasionally, though at first with some circumspection and hesitation, one or two of the boldest 
will let themselves gently fall from their airy height, and glide down upon the lawn, as if to inquire into the state of their future larder; for they scarcely take time to taste the hidden treasures below the sod, but looking suspiciously about, are on the wing in a moment, if an inmate approaches the widow, or a door is heard to shut or open.

About the latter end of the second week, affairs begin to be placed upon a more regular footing; the parties on or about the battlements and weathercock, seem as if they had determined upon a permanent establishment. From early dawn till about ten, there they remain carolling away their communications; at that hour, however, off they go, and till four or five o'clock, are seen no more, throughout the greater part of the day; being absent in the fields, where they may be seen chattering in company with the inhabitants of a neighbouring rookery, or a noisy set of Jackdaws, who have, for time out of mind, been the undisputed tenants of a certain portion of an ancient beech-wood, at no great distance.

About the third week, the plot begins to thicken still more. The field, the lawn, and the weathercock, are no longer the only objects of interest. Detachments may be now seen, prowling busily over the roof, cautiously creeping in and out, from under the projecting eaves, and by the end of the month, the regular establishment, amounting to about thirty, has assembled, and the grand work of the year fairly commences. From this time all is bustle; straws, and nest-furniture, are seen flying through the air in beaks, contriving, nevertheless, to announce their comings and goings by particular harsh or low mut- 
tering cries, according as they think they are watched or not. They are cunning birds, and discover in an instant, whether a passer by has an eye to their movements, and perfectly aware whether he is following his own business or theirs. If he steps onwards, without troubling himself about them, they go in and out with perfect unconcern; but if a glance of curiosity or observation is directed to their motions, they are all upon the alert; the bearer of a tuft to the nest, wheels to the right about, and perching on the naked upper twig of a small beechtree, or the projecting point of a gable-end, sits there, uttering a particular note, which seems to give, as well as words could do, intimation to a mate to be on its guard, as a spy is at hand. If the weather is tolerably favourable, everything goes on smoothly and regularly; but, (and we have, in the journal of our Starlings' proceedings, many instances on record,) should a severe and sudden change occur, a violent storm of snow, or continuance of chilling winds, all operations are suspended; not only the eares, and half-built nests, but even the tower itself, battlements, weather-cock, and all, are deserted, till a return of fine weather, when the Starlings, too, return, and the work again proceeds. At length, the nests are built, the eggs laid, and the young ones hatched. Then a new scene of noise, and activity, and bustle commences, increasing, of course, as the nestlings become older, and more voracious. Then it is that the lawn becomes a favourite resort; hitherto, a few idlers may have hopped and pecked up a stray worm or two, but now the search is a matter of serious occupation. 
Down they come, the sober-coloured hen and the cock, with the sun glittering on his spangled feathers, with claws and beaks as busily employed, as if their very existence depended upon it. All, however, in good social harmony, never quarrelling with the shy and less intrusive Thrush or Blackbird; or with the lively Wagtails, contenting themselves with the lighter fare of the myriads of minute flies and beetles, hovering over the fresh-mown turf.

The noise and bustle go on incessantly, till the young ones are fledged, when for a day or two, they may be seen fluttering about the building, or taking short flights. At length, their strength being matured, old and young collect on the tower, and then wheel away over the neighbouring fields, as if practising for future and more important evolutions. But still the evening finds them roosting near the place of their birth. At last, however, a day comes when all is hushed. No hungry guests are feasting on the lawn, no clamourous throats are calling aloud for food, no twitterings are heard from bough or battlement, not even a straggler is to be seen on the pinnacle of the weather-cock.

The joyous assembly is broken up. The Starlings are gone ${ }^{*}$, and till the autumn, with scarcely an exception, we shall see them no more. Then, about the third week in September, again on their favourite

* The abandonment of their breeding-place depends, of course, upon the season. In 1833, the month of May having been remarkably warm, it occurred on the sixth of June; but we have known it to be delayed till the second week in July; the whole of June having been very unseasonable and stormy. 
perch, the weather-cock, one, or two, or three, may chance to appear towards evening, not with the merry note of Spring; but uttering that monotonous, plaintive, long-drawn, whistling cry, as cheerless as the cheerless season, for which they seem to bid us prepare. That these, and the few other stragglers, occasionally occupying the same post, are our Spring friends, is most probable; for a lame Starling was observed, for eight years, to return to the same nest, and every observation we have made, tends to prove that this is a general instinctive custom of, we believe, every bird whatever.

Having thus giving some report of our Starlings, for the greater part of the year, we will endeavour to follow the main body for the remaining months as yet unaccounted for. To do this effectually would be no easy matter, as we believe, that they are partially migratory, i.e., quitting one part of the kingdom for another, more fitted for their usual mode of life; nevertheless, enough remain within the sphere of our observation, and are to be met with in little flocks, during the summer, in favourite meadows, where food is plentiful, associating with their old friends, the Crows, Rooks, and Jackdaws.

As winter approaches, however, they follow the example of some other birds, such as Larks, Buntings, \&c., and congregate in larger quantities. Not far from the church we have mentioned, there is a considerable sheet of water, occupying nearly thirty acres; flanked and feathered, on the eastern side, by the old beech-wood, already spoken of as the abiding place of the Jackdaws, Its western margin is bounded by an artificial dam, which, as the water 
is upon a much higher level, commands an extensive view over a flat rich country, the horizon terminated by the faint outline of the first range of Welsh mountains. This dam, on the finer evenings of November, was once the favourite resort of many persons, who found an additional attraction in watching the gradual assemblage of the Starlings. About an hour before sun-set, little flocks, by twenties or fifties, kept gradually dropping in, their numbers increasing as daylight waned, till one vast flight was formed amounting to thousands, and at times we might almost say to millions. Nothing could be more interesting or beautiful, than to witness their graceful evolutions.

At first they might be seen advancing high in the air, like a dark cloud, which, in an instant, as if by magic, became almost invisible, the whole body, by some mysterious watchword, or signal, changing their course, and presenting their wings to view edgeways, instead of exposing, as before, their full expanded spread. Again, in another moment, the cloud might be seen descending in a graceful sweep, so as almost to brush the earth as they glanced along. Then once more they were seen spiring in wide circles on high; till at length, with one simultaneous rush, down they glide, with a roaring noise of wing, till the vast mass buried itself unseen, but not unheard, amidst a bed of reeds, projecting from the bank adjacent to the wood. For no sooner were they perched, than every throat seemed to open itself, forming one incessant confusion of tongues.

If nothing disturbed them, there they would most likely remain; but if a stone was thrown, a shout 
raised, or more especially, if a gun was fired, up again would rise the mass, with one unbroken rushing sound, as if the whole body were possessed but of one wing, to bear them in their upward flight. In the fens of Cambridgeshire and Lincolnshire, where reeds are of considerable value for various purposes, the mischief they occasion is often very considerable, by bearing down, and breaking them, as many as can find a grasping hold, clinging to the same slender stem, which, of course, bends, and plunges them in the water, from whence they rise to join some other neighbours, whose reed is still able to bear their weight. This perpetual jostling and breaking down, is the probable cause of the incessant clatter, which continues for a considerable time; indeed, till all have procured dry beds, and a firm footing.

It has been remarked that the flights of these birds have of late years much diminished, a fact to which we can speak from our own experience, for the assemblages which we have just described, as forming so interesting a feature in autumnal evening walks, have long ago ceased; and it is now a rare thing to see a passing flock of even fifty, where, in years gone by, they mustered in myriads.

Their favourite dormitory of reeds, indeed, has dwindled gradually away, since the dam was raised, and the depth of water increased, which may partly account for the diminution; but still reeds are left in sufficient abundance for the accommodation of ten times the number that are ever assembled in the neighbourhood of which we speak.

Under the head of Fringilla, or Finch, which is 
our translation of the Latin word, are included, amongst Sparrows, Goldfinches, and Canaries, tribes of small birds, each exhibiting, in its own domestic habits and arrangements, as much sound philosophy and wisdom, in the management of their concerns, as the wisest of human kind.

Some of these little birds, moreover, seem occasionally to have something like a reasoning, as well as an instinctive faculty. A gentleman had a Goldfinch, which was chained to a perch, instead of being kept in a cage. Its food was put into a box, resembling a water-fountain used for cages, and the little opening at which the bird was fed, had a cover loaded with lead, to make it fall down. The bird raised this by pushing down a lever or handle with its bill, which raised the lid of the box, after which, by putting its foot on the lever, it could feed at leisure. He had also a Redpole, chained on a nearly similar perch; this bird fed from an open box, without the trouble of having recourse to the lifting power, like his neighbour, the Goldfinch. But though the Redpole could have known nothing of the use of the handle, from his own experience, as his food was to be got at without such trouble, yet it seems he must have taken notice of it, and seen, that by touching this handle, he could get at the Goldfinch's food, were he within reach; and this he kept in mind for the day of need; for, one morning, when loose, and his own seed-box empty, he flew at once to the perch of his friend, raised the lid of the seed-box with his bill, and then laying hold of it with one foot, kept it open, till he had made a good breakfast. This apparently trifling circumstance clearly shows 
that birds can, and do take notice of some things, and collect information which may be useful when needed. In this case, it required some time and attention to teach the Goldfinch the use of the handle for holding up the lid of the box; but the Redpole had watched the operation, and learned by observation how to do it as well as his friend*.

The following is another instance of sagacity in a pair of Goldfinches. These little birds had built their nest on a small branch of an olive-tree; after hatching their brood, the parents perceived that the weight of the growing family would soon be too great for the strength of the branch which supported the nest; in fact, it was beginning to give way. Something was to be done, or the nest would fall,this was evident to beholders, and equally so to the Goldfinches; accordingly, they were observed to fasten, by a small string they had picked up, the bending twig, to a stronger and higher branch of the tree, and thus their nest was saved.

Another pair happened to build in the garden of a naturalist, who was fond of observing the manners and habits of birds. They had formed the groundwork with moss and dried grass as usual, but on his scattering small pieces of wool, they, in a great measure, left off the use of the first materials, and employed the wool. He next provided them with cotton, which they immediately collected; the third day he supplied them with down, on which they forsook both the others, and finished their work with it.

It is surprising, too, with what rapidity, in cases * Phren. Journal, No. 34, p. 72. 
of emergency, these small birds can build a nest. A Canary was observed to commence her labours about five o'clock in the morning, from which time, till near seven, she worked so hard that it was completely finished;' she had been often disturbed before, in consequence of building in inconvenient places, which probably induced her to use more than ordinary despatch in this nest, availing herself of early hours, before people were likely to see and interfere.

An African traveller speaks of some singular nests built by birds, which he describes as resembling our Goldfinch; but he probably mistook them for a family of birds nearly allied to them, and known to inhabit the Cape of Good Hope. For, although Bishop Heber found Goldfinches* at the foot of the Snowy Mountains, in India, and in some other parts, where they are caught and sold for about two shillings each, we are not aware that they are known in Africa. The account of the nest, however, is very curious, and, at all events, illustrates the social manners of a set of little birds, like "brethren dwelling together in unity." A tree at a little distance from our wagon, says the traveller who noticed the fact $\uparrow$, had two remarkable nests in it. The one was about four yards in circumference, and the other three, and about a yard in depth. They were built of coarse grass. One of these nests had seventeen holes in the bottom, by which the bird enters;

* The Goldfinch of the East Indies is the Carduelis carriceps, a bird much resembling, but not exactly the same as our British species.

+ Campbell's Travels in Afriça. 
the other had seven. At one time, I saw about a hundred birds come out of them. Instead of being the nest of a single pair of birds, they seemed to be towns of birds, or the property of a single pair, in which they accommodate all their descendants. A horned $\mathrm{Owl}$ had taken possession of the outside of the roof of the largest, for a nest. She was sitting on it, and it appeared from the bones and hair strewed under, that she lived upon the field-mouse. The whole was neatly thatched, and had a hollow in the middle to contain the $\mathrm{Owl}$, but no passage leading to the inside.

OurGoldfinches partake a good deal of this sociable character, for they are usually seen in little flights, calling each other together, and betraying uneasiness if separated from their friends. They are also docile, easily tamed, and have occasionally been known to show a certain degree of confidence in man, when they found no danger to be apprehended, as the following will prove. In the Spring of 1827, a Goldfinch had been lost from a cage, which was left hanging up, and the door open, in the passageentrance to a back court of a house in a country town of the west of England; when a Goldfinch was one morning found feeding in it, and the door was closed upon the prisoner; but, as it appeared to be a female, it was shortly after let out again. In the course, however, of about two hours, it returned, and re-entered the cage, when it was again shut in, and once more, after a short time, released; and these visits were repeated daily, for a considerable time. She was then missing for a few days, but then returned, accompanied by a male bird; when 
she entered the cage and fed as usual, leaving her companion, who appeared rather more shy, sitting on the outside wires of the cage, from whence he shortly flew to a neighbouring tree, until she joined him. They then went away, and were absent so long, that nobody thought anything more about them; when, at the end of seven or eight weeks, she again made her appearance, accompanied not only by her former companion, but by four fullgrown young ones, when she entered the cage and fed as usual. But as she could not persuade her brood to follow her example, she finally went off, and from that time was never seen again.

Small birds seldom live above eight or ten years, but Goldfinches nave been known to live sixteen or eighteen years. We have the authority of a very eminent naturalist *, for one having attained to the age of twenty-three years; at last it grew so infirm, that the people to whom it belonged were obliged to scrape its beak and claws, that it might eat, drink, and sit upon its perch. It had subsisted on poppyseeds chiefly, and had lost its power of flying, and all its feathers had become white, which is contrary to what has been usually observed in aged small birds, whose plumage, at times, assumes a darker shade, particularly if fed much upon hemp-seed. Thus, there are instances of Goldfinches, Bullfinches, and Larks, becoming almost entirely black.

So nearly allied are Canaries to Goldfinches, that they will breed together, and the produce is a very pretty bird (called a Mule), with a strong clear roice, which, in addition to its scarcity, causes it to

$$
\text { * Gesner. }
$$


be much valued, and commands a high price. And yet, nearly connected as they are, the Canary is entirely of foreign origin, being a native of the Canaries (from whence they took their name), a cluster of islands in the Atlantic Ocean, near the coast of Africa. They are very indifferent flyers, which may account for their never having migrated like other birds, and been thus occasionally found in their wild state in other countries. They accordingly, for a long time, remained unknown in Europe ; indeed, it was not till the enterprising reign of queen Elizabeth, about three hundred years ago, when so many of our now common fruits and vegetables, such as nectarines, potatoes, \&c.; and even poultry, such as turkeys, \&c., first found their way into England, that Canaries were introduced; and they were then, for a time, so prized and scarce, that none but the most wealthy could purchase them. But the desire of having them seems rapidly to have spread, for not long after, the Spaniards found them so profitable a trade, that an order was issued for either destroying all the hens that were taken, or setting them at liberty, that the breed might be confined to the islands. The trade in Canary birds is now much greater than it was then, though entirely removed from the original spot. They are reared in Germany and other parts of Europe, by people who bring them over to this country in great numbers, every Spring.

About thirty years ago, a very industrious people, the Tyrolese, were the chief providers. They brought over every year nearly two thousand, which they carried all the way in cages on their backs, and 
made a good livelihood by selling the best at five shillings a-piece. Since then, the trade has, we have reason to believe, still further increased.

Though not very hardy, Canaries might possibly be naturalized in our country, by putting their eggs in the nests of Sparrows, Chaffinches, or other similar birds. The experiment has been partially tried in Berkshire, where a person for years kept them in an exposed aviary out of doors, where they seemed to suffer no inconvenience from the severest weather.

But this singing-bird trade is not confined altogether to Canary-birds;-Piping-Bullfinches, so called from being taught to pipe different tunes, forming a considerable branch of it. In the month of June, the young ones, which are sought for in the nests of wild birds, are taken when about ten days old, and brought up by a person, who, by care and attention, so completely tames them, that they become perfectly docile and obedient. At the expiration of about a couple of months, they first begin to whistle, from which time their education begins; and no school can be more diligently superintended by its master, and no scholars more effectually trained to their own calling, than a seminary of Bullfinches. They are formed first into classes of about six in each, -and after having been kept a longer time than usual without food, and confined in a dark room, the tune they are to learn is played over and over again on a little instrument called a bird-organ, the notes of which resemble as nearly as possible, those of the Bullfinch. For a time, perhaps, the moping birds will sit in silence, not knowing what to make of these proceedings, but after a while they will one by 
one begin to imitate the notes they hear. As soon as they do this, light is admitted into the room, and they are allowed a small supply of food. By degrees, the sound of the organ, and the circumstance of being fed, become so associated, that the hungry bird is sure to imitate the notes, as soon as it hears them. They are then turned over to the care of boys, whose sole business it is to go on with their education, each boy having a separate bird placed under his charge, who plays away from morning to night, or at least, for as many hours as the birds can pay attention, during which time their first teacher or feeder goes his regular rounds, scolding or rewarding his feathered scholars, by signs and modes which he has taught them to understand, until they become so perfect, and the tune, whatever it may be, so imprinted on their memory, that they will pipe it for the remainder of their lives. But though the greater number may be taught their tune, few only, not above five in a hundred, possibly can be so correctly taught as to pipe in perfect harmony; and these, of course, fetch a much higher price than the rest.

Whether from the early habit of associating the utterance of their notes with the agreeable addition of a meal, or from some particular pleasure they feel in singing, we know not, but it so happens that singing and satisfaction generally go together in Bullfinches; for a bird attached to any particular individuals in a family, will always express delight when they approach, and greet them with his wellknown air, hopping towards them on his perch, and practising all his little coaxing ways. An interesting story was once told by Sir William Parsons, who was VOL. II. 
himself a great musician, and who, when a young man, possessed a Piping-Bullfinch, which he had taught to sing "God save the King." On his once going abroad, he gave his favourite in charge to a sister, with a strict injunction to take the greatest care of it. On his return, one of his first visits was to her, when she told him that the poor little bird had been long in declining health, and was at that moment very ill. Sir William, full of sorrow, went into the room where the cage was; and, opening the door, put in his hand, and spoke to the bird. The bird remembered his voice, opened its eyes, shook its feathers, staggered on to his finger, piped "God save the King," and fell dead!

It is often remarked, What impudent birds are London Sparrows! and not without reason. Born and bred in the bustle of the town, they must either live and jostle with the crowd, or look down from the house-tops and die of hunger. Naturally enough, they prefer the former, and every one of our London readers will, we are sure, testify to the cool intrepidity with which this familiar bird will pounce upon a bit of bread, or some other tempting morsel, which happens to catch its eye upon the pavement, and with what triumph and exultation it bears it off to its mate, seated on some window-sill or coping-stone above, or followed, perhaps, by three or four disappointed companions, who were a moment too late in seizing the spoil. Then, for his nest; - while other birds must select their own accustomed spots, the similar tree or bush, the same materials, \&c., the Sparrow, like a bird who knows the world, is everywhere at home, and ready to 
establish himself wherever chance may happen to place him. If he lives remote from towns and cities, and the habitations of men, a tree answers his purpose, and a comfortable nest he will there build, with the rare addition of an arched top into the bargain, which possibly he may have learned from that knowing bird, the Magpie. In default of a tree, or a house; a chink in a rock, or a hole in a wall, suits him; but after all, the nooks and eaves of buildings are his favourite resorts; accordingly, in London, where he has his choice, he will often select droll places. Amidst the carved-foliage of the capital of some Corinthian column, a projection of straws, with now and then a feather, announce a nest in preparation.

But some London Sparrows aspire still higher, one pair having actually built in the Lion's mouth, over Northumberland House, at Charing Cross. A still more extraordinary place was pitched upon by a North-country couple. A coal-vessel from Newcastle, put into Nairn, in Scotland, and while there, two Sparrows were frequently observed to alight on the top of the vessel's mast, while the vessel remained in port. This occasioned no great surprise to the crew; but after putting to sea, the two Sparrows were seen following the sloop, and having come up with her, resumed their posts at the top of the mast. Crumbs of bread were scattered upon the deck, with a view of enticing them down, of which they soon availed themselves, and after eating heartily, again returned to the mast-head. By the time the ressel had been two days at sea, they became much more familiar, and descended boldly for 
the purpose of feeding. The voyage was a long one, lasting for some days, when, on reaching the river Tyne, to which they were bound, the nest, with four young ones, was carefully taken down, and being put, in the presence of the old birds, into the crevice of a ruined house, on the banks of the river, they continued to rear their brood.

When thus upon the subject of young Sparrows, we may direct attention to the very rapid growth of their feathers in hot weather. On the ninth of August, a young one was taken from a nest, with neither down nor feathers upon it, the rudiments only of plumage being visible under the skin, on the back of the head, and along the back; on the sides of the wings, the shafts of the quills had just pierced the skin. Eight days after, another young one was taken from the same nest, covered with feathers, and able to make some use of its wings. Another circumstance is worthy of notice, the old ones had adapted the food to their powers of digestion. The stomach of the first was weak, and filled almost entirely with insects, only one grain of wheat, and a few of sand found. In the second, the gizzard was become vastly more muscular, and contained nine grains of wheat whole, besides some smaller pieces, the remains of several beetles, and some larger gravel-stones.

A Sparrow is not only bold with regard to men, but still more so, on particular occasions, towards other birds. On the edge of a certain lawn, grew a close thick bush. On this lawn, amongst others, the Blackbirds used to come and forage for worms; one day a person happened to be looking at a Black- 
bird, in the act of making off with a prize, when a Sparrow, darting from the thick bush, instantly assailed the Blackbird, and compelled him to drop the worm, of which he took immediate possession. So singular a circumstance induced the observer to look out now and then, when Blackbirds came, and he frequently saw the same piratical practice adopted. by the Sparrow, who thus, by keeping watch in his bush, was enabled to enrich himself on the labours of the larger bird. But notwithstanding this unfavourable feature in his character, he has been known to act with great consideration and kindness to birds requiring his good offices.

In the Naturalist's Magazine, we find the following story in point. A lady, living in Chelsea, was extremely fond of birds, of which she kept a considerable number in cages. Amongst others she had a Canary, which was a particular favourite, but the loudness of his note often obliged her to put him outside of her window, in some trees which were trained up in front of her house. One morning, during breakfast, when the cage was there placed, a Sparrow was observed to fly round about it, then perch upon the top, and twitter to the bird within, between whom and itself a sort of conversation seemed to ensue. After a few moments he flew away, but returned in a short time, bearing a worm or small grub in his bill, which he dropped into the cage, and immediately flew away. Similar presents were received day after day, at the same time, by the Canary, from his friend the Sparrow, with whom, at length, he became so intimate, that he very often received the food, thus brought, into his own bill, 
from that of the Sparrow. The circumstance attracted the notice of the lady's neighbours, who often watched these daily visits; and some of them, to try the extent of the Sparrow's kindness, also hung their birds out at the window, when they found them also fed; but the first and longest visit was always paid by the Sparrow to his original friend the Canary.

Though thus intimate and social with his own kind, it was observed that this Sparrow was exceedingly shy and timid with respect to human beings; for though many were witnesses of the above, they were obliged to keep at a distance, and use great caution, otherwise he immediately flew away. This attention was carried on throughout the Summer, and extended to the beginning of Autumn, when the visits entirely ceased, whether intentionally on the part of the Sparrow, or that he met with some accident, could not be ascertained.

That they will attend to their young, far beyond the usual period, in case of necessity, the following anecdote will prove, though we believe many, if not most birds, will do the same, under similar circumstances; the experiment may be easily tried, by slightly tying the wings of young birds, when nearly fledged, or confining them by a thread to the bottom of the nest, taking care not to injure them. A pair of Sparrows, which had built in the thatched roof of a house, were observed to continue their regular visits to the nest, long after the time when the young birds ought naturally to have taken flight. This unusual circumstance continued throughout the year, and in the Winter, a gentleman, who had all along observed them, determined on finding out the 
cause. He therefore placed a ladder, and, on mounting, found one of the young ones detained a prisoner, by means of a string, or scrap of worsted, which formed part of the nest, having become accidentally twisted round its leg, Being thus disabled from procuring its own living, it had been fed by the continued exertions of the parents.

An unfortunate Sparrow, who had also been made prisoner in his own nest, met with a very different fate, being actually killed instead of preserved by the overzealous kind intentions of his mate. The case occurred in the Spring of 1818, in Surry. The pair were in search of a place for building their nest; and the male bird, finding a tempting hole among the tiles of the roof, got into it; unfortunately, he became entangled in the broken mortar, and could not force his way back. The female saw his situation, and after flying backwards several times, twittering, and apparently in great distress, attempted to pull him out. Several birds were attracted by the accident, and came fluttering round, but were beaten off by the hen Sparrow; she then redoubled her own efforts to get him out, and seizing his beak above the nostrils with her own beak, pulled it so hard, that she killed him. She did not appear, however, aware of the mischief she had done, but continued pulling at the dead body of the unfortunate bird, with as much perseverance, as if it had been alive. She was, at length, driven away by a person, who saw the whole transaction, and with some difficulty extricated the dead bird. Its head was dreadfully mangled, and the beak of the hen had evidently penetrated the brain. About an hour afterwards, a 
Sparrow, supposed to be this hen, was observed sitting on the very spot, where the accident had happened, crouched together, with her feathers all standing up, so as to give her the appearance of a ball, conveying a perfect idea of disconsolate suffering.

Timid as birds are, attachment to their young will frequently change their very nature, and inspire a boldness and confidence, in these little creatures, which calls for respect and admiration. What can be more interesting than the affection of the two Linnets we are about to mention? A nest containing four young ones, scarcely fledged, was found by some children, who resolved to carry them home, for the purpose of rearing and taming the young birds. The old ones, attracted by their chirping, continued fluttering round the children, till they reached the house, when the nest was carried up stairs to the nursery, and placed outside the window. The old birds, soon afterwards, made their appearance, approached the nest, and fed their family, without showing alarm. This being noticed, the nest was soon afterwards placed on a table in the middle of the apartment, and the window left open. The parent birds came boldly in, and fed their offspring as before. Still further to put their attachment to the test, the nest and young ones were placed within a bird-cage; still the old ones returned, entered boldly within the cage, and supplied the wants of their brood as before, and towards evening actually perched on the cage, regardless of the noise made around them, by several children. This continued for several days; when an unlucky accident put an 
end to it. The cage had been again set on the outside of the window, and was unfortunately left exposed to a sudden and heavy fall of rain: the consequence was that the whole of the young were drowned in the nest. The poor parents, who had so boldly and indefatigably performed their duty, continued hovering round the house, and looking wistfully in at the window, for several days, and then disappeared *.

Before we take leave of this tribe of small birds, we would say a word or two respecting the benefit or injuries imputed to them. That they are occasionally mischievous cannot be denied, though it is but fair to add, that they also, like the Rooks before mentioned, repay us by a considerable balance of good. That the Bullfinch feeds on the buds and seeds of trees, there can be no doubt, and that the Chaffinch, though by many considered as a pure feeder on insects, does the same, particularly in early Spring, when he inflicts ruinous injury on the sprouting crops of several plants, is equally true. Sparrows, too, burrow in our stacks, and consume a certain quantity of corn; not, indeed, in the same serious quantities that another bird does, called the Snow-Bunting: these birds, in hard Winters, come from the north in prodigious flocks, and, where they take up their quarters, become quite a nuisance; not so much by what they consume, as by what they destroy; which they do thus. In search of grain they frequent the stack, and then seizing the end of a straw, deliberately draw it out. To such a degree has this been done by them,

* Edin. Phil. Jour. 
that the base of a rick has been found entirely surrounded by the straw, one end resting on the ground, the other against the stack, as it slid down from the top, and as regularly placed as if by hand, and so completely was the thatching pulled off, that it was found necessary to remove the corn.

That some guess may be formed of the possible extent of good or evil occasioned by small birds, we annex the result of our own observations, on the precise quantity of food consumed by certain birds, either for their own support or that of their young, remarking at the same time, that the difference observed in the instances, may be partly accounted for by the different quantity of food required by young birds, at different periods of their growth.

Sparrows feed their young 36 times in an hour, which, calculating at the rate of 14 hours a day, in the long days of Spring and Summer, gives 3500 times per week; a number corroborated on the authority of another writer, who calculated the number of Caterpillars destroyed in a week to be about 3400 .

Redstarts were observed to feed their young with little green grubs from gooseberry-trees, 23 times in an hour, which, at the same calculation, amounts to 2254 times in a week; but more grubs than one were usually imported each time.

Chaffinches at the rate of about 35 times an hour, for five or six times together, when they would pause and not return for intervals of eight or ten minutes: the food was green Caterpillars.

The Titmouse 16 times in an hour.

The comparative weight consumed was as follows. 
A Greenfinch provided with 80 grains, by weight, of wheat, in 24 hours consumed 70, but of a thick paste, made of flour, egg, \&c., it consumed upwards of 100 grains.

A Goldfinch consumed about 90 grains of Canaryseed in 24 hours.

Sixteen Canaries consumed at the arerage rate of 100 grains each in 24 hours.

The consumption of food by these birds compared with the weights of their bodies, was about one-sixth, which, supposing a man to consume food in the same proportion to his weight, would amount to about 25 pounds for every 24 hours! 


\section{CHAPTER II.}

SUBULIROSTRES; AWL-SHAPED BILLS. - MANAKINS ; CURIOUS NESTS OF.-TOMTITS.-WAGTAILS.-REDSTARTS.-ROBINS, \&C.-MIGRATION OF THIS TRIBE. - NIGHTINGALES. - WHETHER THEY RETURN TO SAME NESTS.-EAR FOR MUSIC.-NIGHT SINGINGBIRDS. - PLANIROSTRES ; FLAT-BILLED. - SWALLOW TRIBE - WHETHER CCCASIONALLY DORMANT; INSTANCES OF.- MIGRATION OF.-INSECTS, NUMBER DEVOURED BY SWALLOWS.-SPIDERS, HIGH FLIGHTS OF.-CURIOUS NESTS OF SWALLOWS.-COURAGE OF.

\section{Table XI. Order 2.-Passerine.}

OF the four genera included in this tribe, three are common in England, but the fourth, that of the Pipras or Manakins, is entirely foreign, comprising a number of little birds of beautiful plumage. Some of these species are exceptions to the general rule of classification, as the upper mandible, on examination, will be found, as in the Manakins, notched; in other respects, the beak has a tolerably marked character, being short and usually feeble and flexible; and, as the word subulirostrum implies, awl-shaped, from a Latin word, subula, signifying an awl, and rostrum a beak.

Under the second genus, Parus, are comprehended the various species of Titmouse. Under the third, Motacilla, the Wagtails, Wrens, Robins, and a large family of singing-birds, usually separated from the rest under the term Sylvias, or Warblers; at the head of which stands the Nightingale. Under the fourth, the Alauda, or Larks. The Tomtits are familiar 
to everybody; they might be called our minor Jackdaws, so pert and bustling,-never at rest,-always prying about, peering into every little chink and cranny,-and, even in the breeding season, when most birds retire to more unfrequented haunts, still lurking about our homesteads, and placing their nests in the oddest and sometimes most conspicuous situations. Thus, a pair of Titmice (Parus coruleus), built their nest in the upper part of an old pump, fixing it on the pin in which the handle worked. It happened, that during the time of building and laying the eggs, the pump had not been in use; when again set going, the female was sitting, and it was naturally supposed, that the motion of the pump-handle would drive her away. The young brood, however, were hatched safely, without any other misfortune than the loss of a part of the tail of the sitting-bird, which was rubbed off by the friction of the pump-handle. The opening for the pump-, handle seems, indeed, to be a favourite spot, notwithstanding its danger, as we knew of another pair of Titmice, who, for several days, persevered in inserting close upon the point of the handle, the materials for a nest, though, every time the handle was raised, they were either crushed or forced out, till the patience of the persevering little builders was fairly exhausted.

Another pair of the same species established themselves in a still more singular, though certainly less frequented spot, neither more nor less than in the mouth of the skeleton of a man, who had been hung in chains for murder. Another pair, of a different species (Parus major), had wisely fortified 
themselves in the centre of an old Magpie's nest, where, surrounded by a prickly defence of thorns, \&c., they had built their little warm nest without fear of molestation.

The interior of a skull, as well as the interior of a Magpie's nest, were, (however singular,) at least, better suited to the sedentary life of a bird when sitting on her eggs, than the noisy workshop of a brass-founder's factory; yet, in such an unlooked-for place did a female Water-Wagtail once build her nest, within a foot of the wheel of a lathe, in the midst of the din of hammers and braziers. There, unmolested and unconcerned, she hatched four young ones. The cock, not reconciled to such a scene, instead of taking his part in feeding the nestlings, carried the food he collected to a spot on the roof, where he left it, till the hen fetched it when wanted. She became quite familiar with the men, who were constantly employed in the shop, and flew in and out, without showing signs of fear; but if a stranger approached, she immediately flew off her nest, or, if absent, would not return until he had departed.

We once found a Wagtail's nest under the halfdeck of a pleasure-boat, which was anchored on a sheet of water. Several times, from the discovery of the nest, to the final departure of the young ones, we embarked and sailed about, the old birds keeping a look-out upon our motions, and frequently alighting on the gunwale, and finally rearing and flying off with their brood.

The Redstart, one of our prettiest summer birds of passage, though in its general habits very shy, is frequently in the choice of position for its nest, the 
very reverse. We remember one which built on the narrow space between the gudgeons or upright iron on which a garden-door was hung; the bottom of the nest, of course, resting on the iron hinge, which must have shaken it every time the door was opened. Nevertheless, there she sat, in spite of all

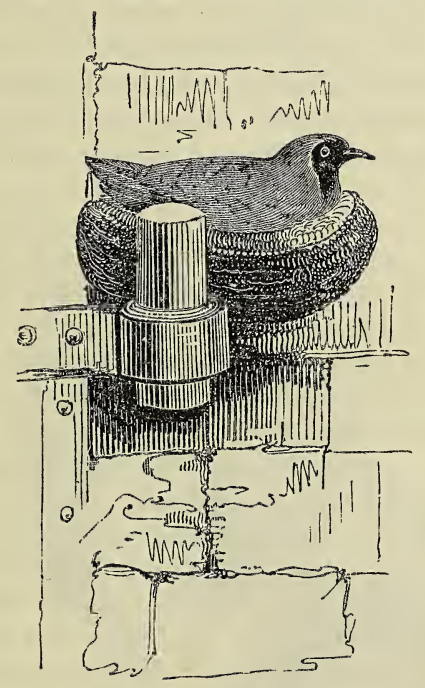

SINGULAR NEST OF A REDSTART.

this inconvenience and publicity, exposed as she was to all who were constantly passing to and fro. Amongst Robin Redbreasts, many instances of strange selection have come to our knowledge, quite as singular as those hitherto mentioned. Thus, we 
knew of one which attempted to build in the library of a gentleman's house, at least, so it was suspected, from a few suspicious materials, such as dried leaves, \&c., having been occasionally found amongst the shelves, without any person being able to ascertain from whence they came. Probably disappointed by perceiving that they were swept away, as soon as deposited, the domestic bird resolved to try another equally sheltered situation, and accordingly, selected the dining-room, which, as the family never entered it till luncheon-time, she had all to herself from the

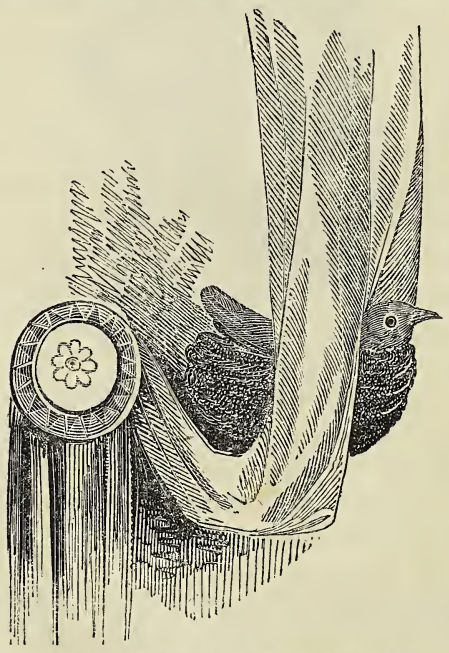

REMARKABLE NEST OF A ROBIN-REDBREAST.

moment the housemaid had done her duty in the morning and retired, leaving, as she was accustomed 
to do, the window open. How long the bird had carried on her operations unnoticed, we know not; but a servant, accidentally moving the drapery of one of the window-curtains, discovered, in the folds of a festoon, the Robin's nest.

In this instance, the bird availed itself of a situation, in which, during the greater portion of the day, she was in solitude and silence; but solitude and silence do not seem essential to all Robin Redbreasts, for we lately heard of a pair which took possession of a pigeon-hole book-shelf in a school, which was constantly frequented by seventy children. The hole selected was at the farthest extremity of the room, immediately above the heads of a junior class of little girls, from four to five years of age, who, much to their credit, never disturbed the bird. There she laid and hatched five eggs. One of the young ones died in a few days, and the body was carried off by the parent-birds. The remaining four were regularly fed in the presence of the children, and in due time reared. Soon after their departure, the old bird repaired the nest, and laid three more eggs, which she attended to with the same perseverance and success. We have often alluded to the frequent return of birds to the same nests, and, perhaps, the most singular feature in this anecdote is, that about twelve years ago, a Robin built in that identical pigeon-hole. Why the visits were not renewed every year, it is impossible to conjecture, but that the pair of the present year were either the same old birds, or young ones of the brood then reared in it, is more than probable, from the circumstance of this pigeon-hole being again selected;

VoI, II. 
when others, forming the school-library, within the same frame-work, would have equally suited the purpose.

Another nest was constructed, and for two successive years, in a still more extraordinary situation, which we give, not on our own authority*, but fully believing it, corroborated, as it may in a manner be said to be, by the proofs of confidence already given. A few years ago, a pair of Robins took up their abode in the parish church of Hampton, in Warwickshire, and affixed their nest to the church Bible, as it lay on the reading-desk. The vicar would not allow the birds to be disturbed, and therefore supplied himself with another Bible, from which he read the lessons of the service. A similar instance occurred at Collingbourne Kingston Church, in Wiltshire, on the 13th of April, 1834: the clerk, on looking out for the lessons of the day, perceived something under the Bible in the reading-desk, and in a hollow place, occasioned by the Bible's resting on a raised ledge, found a Robin's nest, containing two eggs. The bird, not having been disturbed, laid four more, which were hatched on the 4th of May. The still more extraordinary part of the story is, that the cock-bird actually brought food in its bill, and fed the young brood during divine service, which is performed twice every Sunday; and it is further highly creditable to the parishioners, particularly the junior portion of them, that the birds were never molested, and not an attempt ever suspected to be made on the nest, and eggs, deposited in so hallowed a spot.

$$
\text { * Nat. Hist. Mag., No. } 31 .
$$


We can remember, indeed, a Robin hopping more than once, familiarly, as if aware how safe from peril it was at such a moment, upon our own Bible, as it lay open before us reading the lessons on a Christmas-day.

We shall close our anecdotes of singular situations chosen for building nests, with an instance of a Sparrow, who, like the preceding Robin, attached herself to a church, but, instead of the parish Bible, selected the middle of a carved thistle, which decorated the top of the pulpit in a chapel at Kennaway, in Scotland. It found free ingress and egress, by means of the windows, which were left open for the purpose of airing the chapel in the week-days. This bird might literally be said to have verified the words of the Psalmist, "The' Sparrow hath found an house, where she may lay her young, even thine altars, O Lord."

Most of the birds of this tribe are migratory, either partially or altogether so; we mean, that while the Nightingales, Willow-wrens, and others, disappear entirely from our shores, and retire to distant and more congenial climates, others, such as the Wagtails, only move from one part of England to another. The exact times of their appearance and departure, it would be desirable to ascertain, with reference to state of weather, direction of the wind, and prevalence of particular insects, \&c. In short, the same principle holds good in natural history as in other sciences; namely, the importance of noting down observations, however trivial they may appear at the time, as the most minute circumstance may possibly, when connected with other inquiries, 
lead to unexpected additions to our knowledge of the operations of nature, just as a unit or a cipher in arithmetic becomes important, simply by taking its proper place.

The migration of Nightingales is attended with some peculiarities deserving attention. In some parts of England they are to be heard in every hedge-row, filling the air, particularly at night, when most of our other warblers are silent, with their rich melody; while in other parts, to all appearance as well suited to their habits, not one was ever known to be heard; this comparative rarity or abundance not unfrequently occurring in spots only a few miles apart. It might be supposed that the warmest parts of the kingdom were best adapted to their habits; if so, why are they not to be found in the southern parts of Devonshire and Cornwall, where we believe they are never heard? As a general rule, it has been said, that they are not to be met with north of the Trent; but this is not strictly correct, as, in the northern parts of Yorkshire, as far as Wetherby, they are at least occasional visiters.

If they are limited to certain districts by the nature of their favourite food, it might be interesting to discover what this precise food is, so capriciously and unaccountably confined to certain spots. We have alluded, more than once, to the regular return of birds to the same nests and places of their birth; and it might be supposed, that this would solve the mystery, the Nightingales naturally returning only to those spots where, for time out of mind, a train of ancestors might have built before them; but this is not borne out by facts : for a gentleman, who was 
very desirous of introducing these birds on his estate, in a northern part of the kingdom, commissioned a person in London to purchase as many Nightingales' eggs as he could procure at a shilling each. This was done accordingly; they were carefully packed in wool, and forwarded by the mail. In the mean time, men had been employed to find, and take care of several Robin Redbreasts' nests, in places where they might hatch securely. The eggs were then placed under the Robins, by whom the young Nightingales were successfully reared, and remained in the neighbourhood till the usual time for migration; when it is supposed they went away, as they were not seen again after that period, and not one was known to return to the place of its birth. It has been suggested by others, that being a delicate bird, and little calculated to endure the fatigue of long flights, they migrated from the Continent, only to the Eastern coast of England, and then gradually journeyed inland; and consequently, that this would account for their not being seen in Cornwall, and some of the other Western parts of England. But in reply to this, it should be remembered, that the eastern flight across the channel, unless they all embarked at Calais for the coasts of Essex and Kent, is as wide as that between the western coasts of France, where they are plentiful, and the corresponding coasts of England, which they do not visit.

The Nightingale stands unrivalled at the head of our singing birds, and may be called, as old Izaak Walton, the angler, terms them, "chiefest of the little nimble musicians of the air, that warble forth 
their curious ditties, with which nature has furnished them, to the shame of art;" but proud as they may be of their own skill, they are not insensible to the harmony of musical instruments. The German hymn, played upon a flute very softly, near a bush, in which there was a nest, soon attracted the attention of the birds. Scarcely was the air finished, than the cock was heard to chirp; and, when played a second time, it was seen to hop through the bushes with great quickness, towards the place where the player stood, at the same time making a sort of subwarbling, which it soon changed into its usual beautiful and lengthened song.

The Nightingale is usually supposed to withhold his notes till the sun has set, and then to be the only songster left. This is, however, not quite true, for he sings in the day, often as sweetly, and as powerfully as at night; but amidst the general chorus of other singing birds, his efforts are less noticed. Neither is he, by any means, the only feathered musician of the night. The Wood-lark will, to a very late hour, pour forth its rich notes, flying in circles round the female, when sitting on her nest. The Sky-lark, too, may frequently be heard till near midnight, high in the air, soaring as if in the brightness of a Summer's morning. Again, we have listened with pleasure, long after dark, to the warblings of a Thrush, and been awakened at two in the morning by its sweet serenade. The Sedge-bird and Grasshopper-lark may also be heard long after sun-set.

Light, however, seems to be, in most cases, a regulator of their song, for in the case of the Sky-lark and Thrush, as it occurred in the middle of June, 
there was a strong twilight, and we have listened in vain for the Sky-lark's note, beyond the hour above mentioned; though in the northern part of Scotland, and Shetland islands, still further northward, where in Summer it is scarcely ever dark, they are heard throughout the night singing; and, again, to use old Izaak Walton's words, "ascending higher into the air, and then for a time ending their heavenly emplayment, becoming mute and sad to think they must descend to the dull earth, which they would not touch, but from necessity."

\section{TABLE XII. (See vol. i. p. 15.)}

Order 2. Passerine. Tribe 6. Planirostres.

ThIs tribe contains but three genera, two of which, namely, the Swift and the Swallow, are, by common observers, considered as the same, though there is a remarkable difference in the position of their claws; the third is that of the Goat-suckers, whose enormously wide gaping mouths, and short, flat, softish beaks, at once distinguish them from other species.

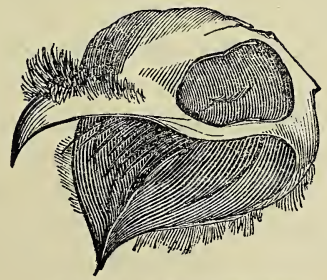

SCULL OF A GOAT-SUCKER. 
As we are not writing a regular book upon the natural history of birds, but confining ourselves chiefly to anecdotes connected with their habits, we shall not pretend to enter into the many details, which it might be otherwise necessary to mention, and shall therefore merely remind our readers that Swallows are the most conspicuous of our Summer birds, that with their first appearance we are accustomed to associate the departure of Winter, and the forthcoming of Summer.

We have four sorts, a little brownish bird, called the Sand-Martin (Hirundo riparia), which leads the way, and, if looked for about the first week in April, may be seen hurrying over the surface of large sheets of water, or rivers, near to which are banks of sandy soil, in which they burrow, and build their nests; the Chimney-Swallow (Hirundo rustica), with his red patch upon his throat, and the Martin (Hirundo urbica), follow nearly together; the large screaming Swallow or Swift (Hirundo apus), being the last to come, and the first to go.

We have already spoken of migration (vol.i., p. 100), and the little difficulty in accounting for it, rapid as these birds are in motion, and fitted by their length of wing for long-continued flight. Notwithstanding which, many naturalists formerly, and some few still, maintain that they do not desert us entirely, but become dormant during the cold weather, or, what is still more extraordinary, plunge into water, and remain buried in the mud at the bottom, till the warmth of Spring revives them, when they awaken from their slumbers, and again become tenants of the air. 
We will not positively assert that Swallows can, under any circumstances, continue through the Winter in a dormant state, and still less, that they can exist at the bottom of water, but as instances well attested, without assignable reasons for deceiving, are abundant, coming too from different and distant quarters, they at all events merit some notice ; and that future observers may, by being made acquainted with a few of the instances given, be enabled to clear up all doubts, or explain what may still remain to some a mystery, we will give those cases which have come to our knowledge, on the most respectable authority.

On the 16th of November, 1826, a gentleman residing near Loch Awe, in Scotland, having occasion to examine an out-house, used as a cart-shed, saw an unusual appearance upon one of the rafters, which crossed and supported the thatched roof. Upon mounting a ladder, he found, to his astonishment, that this was a group of Chimney-Swallows (Hirundo rustica), which had taken their winter quarters in this exposed situation. The group consisted of five, completely torpid; and none of the tribe to which they belonged had been seen for five or six weeks previously; he took them in his hand as they lay closely and coldly huddled together, and conveyed them to his house, in order to exhibit them as objects of curiosity to the other members of his family. For some time they remained to all appearance lifeless; but the temperature of the apartment into which they were carried being considerably raised, by a good turf fire, they gradually evinced symptoms of reanimation; and in less than a quarter of an 
hour, finding that they were rather rudely handled, all of them recovered, so as to fly impatiently round the room, in search of some opening, by which they might escape. The window was thrown up, and they soon found their way into the fields, and were never seen again.

A similar circumstance, though, from the place of its discovery, it must refer probably to Sand-Martins, was related by a gentleman, who found two Swallows in a sank-bank at Newton, near Stirling, quite dormant.

Again at Belleville, in North America, a gentleman observed one evening, a little after sun-set, late in the Autumn, a vast number of Swallows collected together, high in the air, and hovering over a particular spot. Having been informed by one of his school-fellows, when a boy, that Swallows had been seen to dive into a mill-pond and disappear, he determined to watch these, and in about ten or fifteen minutes, as darkness came on, they lowered their flight, and gathered themselves into a smaller circle, and at length poured down into a very large hollow sycamore tree. It was observed that they came out for several successive days, and returned in the evening in the same manner. In the following year the tree was cut down, the hollow was then found to be about six feet in diameter, and filled, six inches deep, with bones, feathers, and other remains of dead birds, such, probably, as were too old, or too feeble to fly out in the Spring. They apparently must have occupied the tree for several years. Two other trees were subsequently seen, fallen, with similar appearances*.

* Phil. Mag. vol. L. p. 317. 
Again, about half a dozen Swallows were found a few years ago, in a torpid state, in the trunk of a hollow tree, by a countryman, who brought them to a respectable person, by whom they were deposited in a desk, where they remained forgotten till the following Spring, when, one morning, on hearing a noise, he opened the desk, and found one of them fluttering about; the others also began to show signs of life, and, upon being placed out of doors in the sun, speedily arranged their plumage, took wing, and disappeared.

On the second of November, 1829, at Loch Ransa, in the island of Arran, a man, while digging in a place where a pond had been lately drained off, discovered two Swallows in a state of torpor: on placing them near the fire, they recovered. One unfortunately escaped, but the other was kept by the man for the purpose of showing it to some scientific persons.

In addition to these cases relating to Swallows, we have two instances of dormant Corncrakes, which are also migratory Summer birds. A farmer at Aikerness, in Orkney, about mid-winter, in demolishing a mud-wall, there called a hill-dike, found a Corncrake in the midst of it-a bird which is plentiful in Summer, but departs, like Swallows, at the close of that season. It was apparently lifeless, but being fresh to the feel and smell, it was placed in a warm situation. In a short time it began to move, and, in a few hours, was able to walk about, and lived for two days in the kitchen; but, refusing all food, it died.

The other occurred at Monaghan, in Ireland, where a gentleman, having directed his labourers in 
Winter to remove a large heap of manure, that had remained undisturbed for a great length of time, perceived a hole, which was supposed to have been made by rats; it penetrated to a great depth, but at its termination, instead of rats, three Corncrakes were discovered, as if placed there with the greatest care, not a feather being out of its place, and apparently lifeless. The birds, on examination, were, however, considered to be in a torpid state, and were placed near a fire in a warm room. In the course of a short time, a tremulous motion was observed in one of their legs, and soon after a similar motion was noticed in the legs and wings of the whole, which at length extended itself to their whole bodies, and, finally, the birds were enabled to run and fly about the room*.

Humming-birds also, we are assured, are sometimes overtaken by cold, and have been known to fall into a torpid state $t$.

It has been argued that as some animals, such as the bear, dormouse, \&c, are subject to long seasons of torpidity, during which time they require no food, Swallows may in like manner continue in a torpid slumbering state throughout the Winter. A few experiments, carefully attended to, might throw additional light upon the subject. If Swallows, for instance, were exposed to cold, at or near the freezing point, sleep might overcome them, just as it does travellers who have been accidentally exposed to the inclemency of the weather: on becoming benumbed, we know that drowsiness commences, which, if not

* Ed. Journ. vol. viii.

† Phil. Mag. vol. xxii. 
shaken off, by active exertion, inevitably ends in death. If man is subject to this effect, as well as some animals, why may not Swallows? Two of these birds were, a Summer or two ago, caught, and placed for twenty-four hours in a cage suspended in an ice-house ; at the expiration of this time, one was found dead, but the other was alive, and, when released, flew away in perfect vigour. In this case, therefore, nothing was learned from the experiment; but the constitution of the bird may be different towards the close of the season, and better prepared for a Winter's sleep. And that this, to a certain degree, is the case, may be collected from the following statement:- " On the 22nd of September, at about seven o'clock in the morning, with a drizzling cold rain, and wind easterly, a vast number of Chimney-Swallows were observed hovering over, or resting on a house, in the South of England: in the course of the morning large flocks continued to join this main body. The appearance of the whole was, however, very letbargic and moping, and so tame were many, that they were taken by hand from the window-sills, on which they had perched. For experiment sake, our informant put his arm out of an attic-story window, and in a short time one of them settled on his hand; he withdrew it, expecting the bird would fly off, but there it remained, giving him ample time to examine it more narrowly. Its eyes appeared nearly shut, its wings and tail drooping, and its whole frame in a torpid state ; finding some force necessary to take it from his hand, he had the curiosity to whirl it round several times, but to no purpose, the only ex- 
ertion the bird used, being a languid expansion of the wings for preserving its seat, which it did by grasping its claws, so firmly as to draw blood from the hand. In the course of the day he collected twenty, confining them at large in a room.

"On their first introduction they perched themselves on various parts, and appeared as languid as their neighbours out of doors. In a short time, one, which had placed itself on the mantel-piece near a small fire, was observed to become more lively, moving its head with a good deal of animation, and seeming to enjoy the warmth. On this the fire was increased, and the air in the room considerably warmed. On which the little prisoners soon became more sprightly, and flew about the room as rapidly as on a Summer's day in the open air. Between eight and nine o'clock the main body went off, with the exception of five or six, and were absent for about two hours, when they returned in seemingly greater numbers than before, and remained till the following morning; when, between nine and ten o'clock there appeared a great commotion amongst them, and within a few minutes they all took their departure in a south-east direction, appearing to have entirely cast aside their torpidity, and to be as full of animation as ever. Their flight was at a great height, further than the eye could reach, to which they rose by several circumvolutions, that is, flying round in large circles, just as Kites and Ravens do when they soar. About half an hour after they had flown off, two of those confined in the room were released. For about half a minute they flew exactly in the contrary direction from their 
companions, and seemed bewildered; they then, however, turned about, and darted away with the greatest velocity, in the same direction as the others. The remainder were let out in the course of the day, at intervals, between the hours of eleven and four o'clock, all of which took the same direction as their predecessors."

This is one of the most minute and satisfactory accounts of migration we ever met with, and although these birds were not, in this case, compelled by immediate hunger, (for the stomachs of several found dead were full of the remains of their common food, consisting of small insects, spiders, \&c.) there nevertheless can be no doubt that one of their chief reasons for quitting us is want of food; for in Ceylon, where the species are said to be similar to our own and where the climate is such as to allow of a perpetual supply of food, they never quit the island. Why, indeed, they ever should quit those favoured spots, where they can exist in the midst of plenty, without wandering to distant regions, is the most surprising part of their history; and it is difficult to account for a flight of Swallows departing from the warm climate of the tropics, to pass their short Summers in such remote and uncongenial quarters of the globe as Iceland, in the north, and Port Famine, near Cape Horn, in the south, in both of which inhospitable regions they are found, as well as near the still more cheerless shores of Hudson's Bay, where the supply of food is more particularly precarious, owing to the large masses of ice, which hang upon the northern sides of the bay until the beginning of

* Perceval's Ceylon. 
August; every breeze from which sweeps over the land, chilling the insects and driving them to shelter; and when this happens, the Swallows suffer severely, and many of their young perish. Whereas, in the interior of the same country, beyond the reach of these ice-blasts, they run no risks, and rear their broods without difficulty.

The quantity of insects devoured by Swallows is far greater than most people imagine. On picking up a Swift that had been shot, a number of minute flies or beetles, some mutilated, and others scarcely injured, were observed crawling out of the bird's mouth; the throat and pouch seemed absolutely stuffed with them, and as many were collected, as when pressed close could conveniently be contained in the bowl of an ordinary table-spoon. If nearly examined, a great proportion of these minute insects will be found of one particular sort; and it is a curious fact, that by far the greater part, indeed we may say, from repeated examination, all of those which suddenly fly into our eyes when walking or riding, are of the same genus (Staphylinus), if not the same species (Staphylinus brachypterus), devoured by Swallows. Most persons may have noticed, in the Summer season, a disagreeable looking insect, running rather briskly across a sand or gravel walk, which, if touched or disturbed, immediately throws up its tail, from whence project two formidable-looking spines; it appears to have no wings, but it is provided, nevertheless with a pair, most beautifully folded up beneath two little short wing-cases; still, however, these wings are disproportioned to the size of the insect, and we may therefore reasonably con- 
clude that it is by no means so active on the wing as others with a larger expansion, and consequently unable so adroitly to guide itself, and avoid danger; which may account, at the same time, for its being more readily seized by the Swallows, and also for its being carried headlong into the eye, if the eye happens to be in the line of its accidental course. Those who have experienced the annoyance of these minute intruders, will well remember the extreme pain felt, as soon as the eye closes upon its prisoner: this is occasioned, as the annexed figure will show, by the irritation produced, when the insect, as in the case of its larger representative on the gravel walk, on being caught, instantly darts up its tail, covered with similar sharp and fork-like appendages.

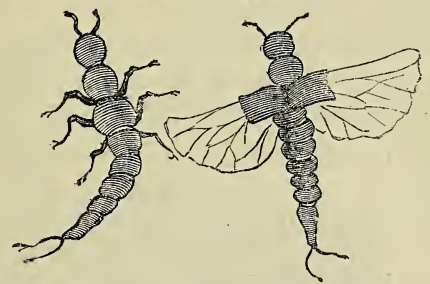

STAPHYLINUS BRACHYPTERUS, MAGNIFIED,

Our readers, on perusing the above narrative of the torpid state of the migratory Swallows, may have been surprised that spiders should be found in the mouth of a bird collecting its fodd on the wing; but they will be still more so, in hearing that spiders form a very considerable part of the food of the Swift, which flies higher in search of insects than any other insect-feeding bird. The fact is, the air is abundvoL. II. 
antly tenanted with small spiders, and to a height almost incredible. Of the quantity we may form some idea, by the perfect carpetting of webs which are occasionally seen in an Autumnal morning, glistening with moisture. These are the webs of the gossamer-spider, which, rendered heavier by the dew collecting on their slender threads, fall to the ground, and cover whole acres.

Of the height to which these spiders rise, we have the evidence of a person, who, from the summit of York minster, nearly two hundred feet above the ground, found himself surrounded by immense flights of little spiders, floating upwards on their airy webs; and could perceive them in equal numbers, higher in the air, as far as the eye, aided by a good telescope, could reach.

It is a common weather rule, that when Swallows fly low, there will be rain, but when high, it will be fair. The reason may be readily guessed. They feed entirely, as we have said, upon insects; and the flight of insects depends, in a great degree, on the state of the air; if it is clear and dry, they rise; if moist, or likely to be so, they keep nearer the ground, and thus, the Swallow, like the hand of the clock, moved by invisible wheels and springs, tells us when we may expect the weather to be moist or dry.

We have noticed some odd places chosen by birds for their nests, but none, perhaps, more curious than those selected by Swallows, at the same time affording another proof of the constant return of birds to the same places. At a nobleman's house in Scotland, the kitchen was in a building separated from 
the main part of the house by an open court, but connected with it by a covered passage, supported by posts, and open to the south. In the cormer of the passage, close to the kitchen-door, a bracket was placed for holding a lamp, which was taken down to be trimmed every day, and lighted every evening. On that bracket a Swallow, and it is believed the same Swallow, built her nest for three or four years, quite regardless of the removal or light of the lamp, and the constant passing and repassing of the servants. On the opposite side of the same open court, the great house-bell was hung, under a wooden cover, fastened to the north wall of the house. It was a large bell, and was rung several times a-day to call the servants to their meals. Under the wooden cover of this bell, the same Swallow, it is believed, which had formerly built on the bracket for the lamp, built a nest for several years, and never was in the least disturbed by the ringing of the bell, or the rattling of the rope.
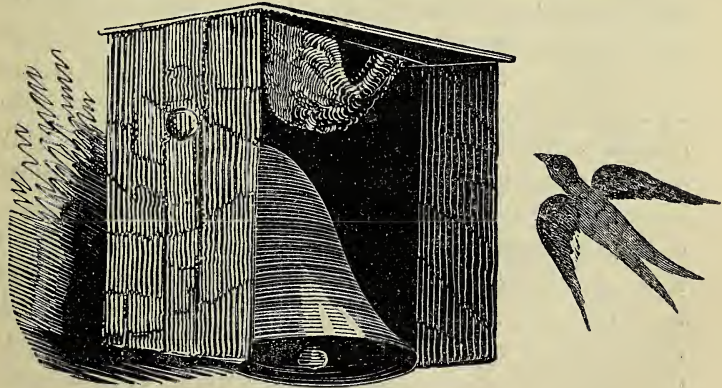

CURIOUS NEST OF A SWALLOW. 
One of the chimneys in a house at Blois, in France, was surmounted by an old moving iron chimney-pot, placed there to prevent it from smoking; the fire-place with which it communicated, having been bricked-up, it became a safe place for building in. Accordingly, as such, it was pitched upon by a couple of Swallows, and in it, moved as it was by every wind, and making at every motion a dismal creaking noise, for two successive years, did they build their nest; and often were they seen for minutes together, when the wind was high, trying in vain to get into it, its constant motion rendering entrance an affair of some difficulty.

Timid as they appear to be, when occasion calls for exertion and courage, they can not only fight a good battle, but manifest a good deal of generalship. A pair of Martins, having built in a corner of a window, one of which, from a remarkable white feather in one of its wings, was known to be the same bird which had built there the year before, had no sooner finished their nest, than a strange Swallow conceived the plan of taking possession of the property, and once or twice actually succeeded in driving the owners out. For a week, there was constant battling. At length, the two rightful owners were observed to be very busily engaged in lessening the entrance into the nest, which, in a short time was so reduced, that it was with difficulty they could force themselves into it singly. When they had accomplished their object, one or other of them always remained within, with its bill sticking out, ready to receive any sudden attack. The enemy persevered for a week, but at length, finding its 
prospects hopeless, left the pair to enjoy the fruits of their forethought.

The latter of the two preceding anecdotes tends to corroborate a more bold and sagacious measure, adopted by a pair of Swallows, no doubt those of the preçeding year; which, on arriving, found their old nest already occupied by a Sparrow, who kept the poor birds at a distance by pecking at them with its strong beak, whenever they attempted to dislodge it. Wearied, and hopeless of regaining possession of their own property, they at last hit upon a plan which effectually prevented the intruder from reaping the reward of its roguery. One morning they appeared with a few more Swallows, - their mouths distended with a supply of tempered clay,and, by joint labour, in a short time, actually plastered up the entrance-hole, thus punishing the Sparrow with imprisonment, and death, by starvation. This instance of apparent reasoning, occurred at a rectory-house, in Lancashire; but a similar story is on record, near London, of a pair of Swallows calling in the assistance of their neighbours for the very same purpose.

Swallows, too, like the Raven, (mentioned vol. i., p. 220), and probably many other birds will, when deprived of their mates, provide themselves with others, a fact, of which the following account, from an, eye-witness, is a proof:-A couple of Swallows built their nest in a stable; the female laid her eggs, and was observed to continue motionless beyond the time of hatching, while the male fluttered about, or occasionally settled on a projecting nail, uttering plaintive notes, which induced some persons at 
length to examine the nest, when the female was found to be dead; she was accordingly thrown away. The male then went to sit upon the eggs, but after remaining about two hours, flew off, and in a short time returned with another female, which sat upon the eggs, and afterwards hatched and fed the young ones, till they were able to provide for themselves*.

* Forster's Travels in North America. 


\section{CHAPTER III.}

SWALIOWS' NESTS CONTINUED.-EDIBLE NESTS, EAST INDIES.-GOAT-SUCKERS.-MODE OF SEIZING MOTHS. -CAVERN WITH THEIR NESTS DESCRIBED.-TENUIROSTRES ; NARROW-BILLED.-NUTHATCH.-TREECREEPER.-BEE-EATER.- HOOPOE. - KINGFISHER. HUMMING BIRDS. - CLIMBING BIRDS. - CUNEIROSTRES; WEDGE-BILLED.-JACAMA. - ANIS. - CUCKOO. -ANECDOTES AND HABITS OF.

Swallows' nests, as we know, are, in this country, invariably made of mud externally; but, in America, an intelligent traveller, Sir Francis Head, informs us, that he met with those of the common species building in hollow trees; the place he observed them in being beyond the dwellings of man, and the accommodation of houses and walls; and that they formed their nests of the minute fibres of roots, strongly cemented together, so as to make a compact ressel, as tight as a China cup.

But the nest most worthy of notice is that of a small Swallow, met with in the East Indies (Hirundo esculenta). The species, by whose labours these nests are formed, is about the size of the common Martin. Its chief peculiarity consists in having the width of its bill increased by a naked piece of skin, something like parchment, which, when the bill is shut, lies folded together, but which, when open, is considerably extended, enabling the bird to catch with greater ease, while on the wing, the insects that serve it for food. They are exceedingly light and tender; ten of them together weighing little more 
than two ounces and a half. There are two places in particular, near Batavia, where they are found in great numbers; both in a range of high land, extending towards the sea. There are, indeed, other places in the same district, or at a greater distance from the coast, which either produce a few, or are carefully concealed by the Javanese, who are unwilling that others should interfere with the profit they make by selling them to the Chinese, who are the chief purchasers.

The two bird-mountains above alluded to, are insulated rocks, hollow within, and pierced with a great number of openings. Many of these openings are so wide that a person can enter them with ease; others are attended with more difficulty, and some are too small to admit of intrusion; in these, therefore, the poor little birds are alone safe from robbery. To the walls of these caverns, the birds affix their small nests, in regular rows, and so close, that for the most part they adhere together. They construct them at different heights, from fifty to sixty feet, sometimes higher, sometimes lower, according as they find room; and no hole or convenient place, if dry and clean, is left unoccupied; but, if the walls be in the least wet, or moist, they immediately desert. them. At day-break these birds fly abroad from their holes, with a loud fluttering noise, and in the dry seasons rise so high into the atmosphere in a moment, as they have to seek their food in distant parts, that they are soon out of sight. In the rainy season, on the other hand, they never remoye to a great distance from their breeding-places.

About four in the afternoon they again return, 
and confine themselves so closely to their holes, that none of them are seen any more flying, either out or in, but those which are hatching. They feed upon all sorts of insects which hover over stagnant waters, and these they easily catch, as they can extend their bills to a great width. They prepare their nests from the strongest remains of the food which they use, and not of the scum of the sea, or of sea-plants, as some persons have supposed. They employ two months in preparing their nests; they then lay their eggs, on which they sit for fifteen or sixteen days. As soon as the young are fledged, people begin to collect their nests, which is done regularly every four months; and this forms the harvest of the proprietors of these rocks.

The business of taking them down from the rocky ledges on which they are placed, is performed by men who have been accustomed, from their youth; to climb amongst these dangerous places. They construct ladders of reeds and bamboos, by which they are enabled to ascend to the holes; but, if the caverns are too deep, they employ ship-ropes. When they have got to the bottom of a cavern, they place bamboos, with notches in them, against the wall, if these be sufficiently long to reach the nests, but, if not, they stand on the ladders, and pull the nests down with poles of bamboo made for that purpose. This employment, which is very dangerous, sacrifices the lives of a great many men, and particularly of thieves, while attempting to rob the caverns at improper seasons. For this reason, small watch-houses are everywhere built in the neighbourhood.

The mountaineers, who are the persons chiefly ac- 
customed to this employment, never undertake their labour till they have slaughtered a buffalo, as a propitiatory sacrifice, which is the usual preparation made by the Javanese for all their undertakings. On such occasions they mutter over a few prayers, anoint themselves with aromatic oils, and fumigate the holes with sweet smelling substances, which they conceive to be charms against accident.

At the chief of these caverns, in the island of Java, a protecting female deity is worshipped, under the name of Princess of the Southern Sea. A small hut, with a covered sleeping-place, is there appropriated for her, together with various elegant articles of dress, which none under the rank of a princess can wear; and every Friday, when the nests are taken down, incense is continually burnt, and the body and clothes of every one who intends to ascend the rocks must be exposed to it. To afford them light in the cavern, they use torches made of the resinous gum of a large tree.

The collecting of these nests continues no longer than a month, and, as already mentioned, may be repeated three times in the year. Some believe that it may be done a fourth time; but this is not probable, as all experienced people brought up to this employment confidently assert, that a nest, as long as it remains entire, is continually enlarged by the bird, or made thicker, until it is entirely deserted by her, when it becomes dry or hairy in the inside. When the nests have been collected, no further trouble is necessary than to dry and clean them; after which they are put in baskets, and sold to the Chinese. The price of them depends on their whiteness and 
fineness. Those of the best sort are exceedingly scarce. They are sold at the rate of from eight to fourteen hundred rix-dollars per one hundred and twenty-five pounds, which amounts, in our money, to the sum of from thirty to forty-two shillings per pound. This bigh price, and the great avarice of the Chinese, give rise to much dishonesty and thieving. The two places above mentioned were, about fifty years ago, sold by auction, by the Dutch East India Company, to the highest bidder, who received for them above twenty thousand pounds more than they expected, which proves the value and quantity of these singular productions. About two thousand five hundred pounds' weight of these nests are collected every year in the island of Java, which, at an arerage of the above prices, amounts to about five thousand pounds a-year.

Some of these bird-caverns are dreadfully exposed, particularly a few situated on the coast; these are washed by the sea, which forces its way so deep into the latter, that fish may be caught in it; but, on account of the steepness of the rocks, the nests can only be collected at the most imminent risk. The young birds are eaten, both by the Javanese and the Europeans in India; but they are considered to be very heating, and are, moreover, difficult to procure. The nests, on the other hand, when they have been boiled to a kind of slimy sort of soup, exposed in the night-time to the dew, and mixed with sugar, are exceedingly cooling, and they are, therefore, much used in violent fevers; they are, also, prescribed, and with great success, in cases of hoarseness and sore throats. They are, however, 
not supposed to be possessed of any very superior medical qualities, and are chiefly sold as articles of luxury, and ornaments for the tables of the rich Chinese. Their mode of using them, is, to put them, after being well soaked and cleaned, along with a fat capon or duck, into an earthen pot closely covered, and suffered to boil over a slow fire for twenty-four hours.

Swallows are generally hailed as welcome guests, and allowed to fix their plastered dwellings, without molestation, under the eaves or corners of windowsills; but, when very numerous, they are apt to occasion a good deal of dirt, and when once established, it is by no means easy to drive them away. This, however, may be effected by rubbing the corners of the windows with soft-soap early in the Spring. This was practised with success, in a house, the windows of which used to be quite darkened by the dirt, \&c., occasioned by a colony of nests. The Swallows, on their arrival, began to build as usual; but as fast as they attempted to attach their materials to the stone, they slipped off. For some days, they renewed their attempts, but then gave the matter up; and what was very remarkable, although the soaping was never renewed, not a single Swallow ever afterwards attempted to build on the windows, not even on those which had not been soaped, though several built in the adjacent out-houses and immediate neighbourhood.

But we fear we are suggesting a needless remedy for an inconvenience not likely to recur; for, within the last few years, particularly since 1809, these pretty social Summer visiters, like our Starlings, 
have been decreasing in numbers, in the most unaccountable manner, not only in England, but in almost every part of the Continent.

The same church-steeple, which has enabled us year after year to watch the Starlings*, was formerly a source of equal interest respecting Swallows; nests were snugly concealed in sheltered nooks, the belfry itself being a favourite resort, notwithstanding the frequent peals, which might have shaken the nerves of less-determined birds; and a few days before their final departure, it was pleasant to watch them, marshalling their newly-fledged broods along the projecting dripstones and mouldings on the eastern side of the old gray tower, enjoying the morning sun. As the numbers collected seemed far to exceed those which were reared there, it appeared as if the united broods of the neighbourhood, had by common consent, fixed upon it as a favoured central rendezrous. All was exhilaration,-a perpetual twittering was kept up; a few of the old ones would, after flying in circles round the battlements, pass screaming by the reposing ranks of young ones, and then, as if by word of command, the whole body would sweep from their resting-places, and, in loud chorus, take a wider circuit, as if to try their powers; and then, in an instant, crowd again together, and rest as before. But those days are gone by; year after year the numbers have fallen off, and at present we are not aware of even a single nest.

There may be, however, some solitary exceptions to their diminution; one, indeed, fell under our observation, on the 17 th of June, 1833, when we * See page 2 . 
were delighted with a little colony of upwards of fifty nests, attached in closest order beneath the eaves of a lone public-house, at which the coach stops for some minutes, between Stamford and Huntingdon. We do not at present recollect the name, but it had an additional attraction in its sign, which was a head of Locke, said to be by Sir Thomas Lawrence, when in his earlier days a guest at a house in the neighbourhood.

The Goat-suckers or Fern-Owls, so called from being frequently met with on heather, or wild places

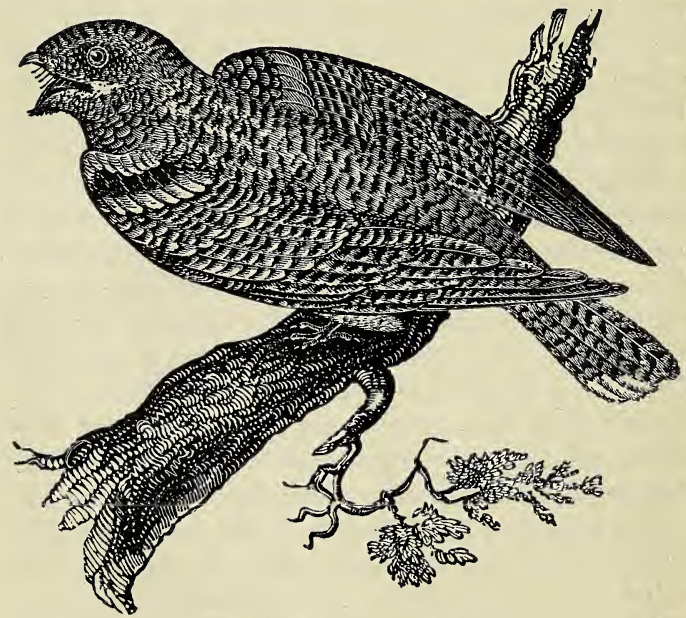

THE FERN-OWL, OR GOAT-SUCKER.

abounding with fern, ought, more truly to be called Moth-Hawks, from their feeding almost entirely 
upon these soft-winged insects, which they catch up in their flight, however dark it may be. To human beings, who at dusk can scarcely trace a swift-flying moth as it glances by, it is inconceivable how this bird can contrive to make its constant meals on such precarious prey. Nature, however, has amply provided it with never-failing means of feasting to its satisfaction. In the first place, the eye is large, full, and clear, like the Owl's, and so thin and transparent is the membrane separating it from the base of the upper mandible, that as it flies, when in search of food, with its mouth open, it has been surmised by some naturalists, that the bird is enabled thereby to keep a look out forward, as well as on either side, through the thin bony membrane. At all events, without this odd addition to great powers of vision, a skull more than half filled up with eye-sight, must enable the possessor to see more clearly in the dark than we can conceive possible. But in the next place, look at the mouth (see figure, p.62and 39), such a prodigious opening as it is, with a fringe of strong bristles on either side of the nostrils, the use of which is this :- that as it flies along, if a moth crosses the pathway of these widely-opened jaws, the bristles fetter the insect's wings, and help to imprison it beyond the power of escape.

This bird has moreover another peculiarity, adapted for the capture of moths, namely, a kind of glutinous liquid, which exudes from the upper part of the bill, and is so adhesive that small insects are retained by it, and it is thus enabled to imprison and swallow a number of them together; and what is still more singular, that, although swallowed, they still con- 
tinue to exist; a fact only lately, we believe, known, and discovered accidentally by a person who, having one evening shot a Goat-sucker, was surprised to see a moth come out of its mouth and fly away; and on opening the crop the next morning, it was found to contain several other moths, which had lived all night in this strange prison, and, when released, ran about the table fluttering their wings.

In the last place, its foot is doubly fitted for grappling its volatile game. We give it in the annexed figure, of its natural size, not much larger, it will

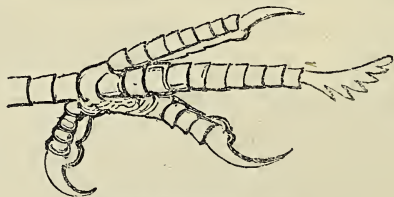

GOAT-SUCKER'S FOOT.

be seen, than that of a Sparrow, though the bird in size is little less than a Pigeon. The hind claw is remarkably small, but it is what is termed reversible, that is, it can turn forwards, and act in concert with the other three, which must be very convenient in catching such nimble things as moths; but it has another peculiarity, - the middle claw serrated or toothed, very much like the Heron's, and for the same purpose, that of preventing the escape of quick and active prey. That this peculiarity is intended for the purpose stated, may be inferred from some of the largest species, in size almost equal to a Raven, being without a serrated claw, and whose food has been ascertained to consist of the fruit of 
the palm. Another use has been also assigned to these toothed-claws, - that of enabling them to carry off their eggs, if disturbed: some naturalists asserting that they have such a power, and have been actually seen in the act of flight with eggs in their claws; but the fact has been denied by others. That it is not impossible, however, even for birds without such claws, to remove their eggs, we can vouch from good authority; for a Pheasant having laid her eggs in a fallow field, became dissatisfied with her situation, and removed them to a less frequented spot in the same field, where she deposited them in another nest, which she had previously scraped together.

With all these united powers, swift and silent too in flight as it is, no wonder that this bird makes such havoc amongst the, to us nearly invisible, multitudes that people the silent air on a summer's night. At twilight, it may sometimes be seen at work, flitting about, hovering now over one spot, then over another, occasionally dropping or tumbling over, as if shot; this is the moment, when having seized a moth, the bird reaches it to its mouth, and loses its balance, when again rising, it glides away like a ghost, till lost in shade. We have but one species visiting England, but in foreign countries there are many. In South America, particularly, they abound: the curious retreats of one species of these birds are thus described by the celebrated traveller, M. De Humboldt, who visited a dark chasm in the rocks called the Cavern of Guacharo, frequented by a species (Caprimulgus steatornis) whose young were caught to furnish oil :

"A frightful noise, made by these birds, issued voL. II. 
from the dark recesses of the cavern; their shrill and piercing tones reverberated from the arched roofs, and were re-echoed from the depths of the cave. The Indians, by fixing torches to the end of a long pole, pointed out their nests, arranged in funnel-shaped holes, with which the whole roof of the grotto was riddled. As the travellers advanced, the noise increased, the flare of the torches alarming the birds still more. When it ceased for a few minutes, distinct moans were heard from other remote branches of the cavern, the alternate responses of other flocks of these birds. The Indians, every year about Midsummer, descend into the cave, furnished with poles for the purpose of destroying the nests. At this time many thousands of birds are killed, and the old ones, as if to protect their broods, hover over the heads of the Indians, uttering the most dreadful shrieks. The young that fall to the ground are immediately ripped open, to procure a sort of unctuous or fatty substance with which they are then loaded. At this period, which is commonly termed the oil-harvest, the Indians construct little habitations of palm-leaves, close to the opening, and even in the mouth of the cavern. Here the grease of the young birds just killed is melted over a fire of dry sticks, and run into pots of white clay. This grease, known by the name of Guacharo butter or oil, is semi-liquid, transparent, and without smell, and so pure that it may be kept a twelvemonth without becoming rancid. At a neighbouring convent, visited by these travellers, no oil but that of the cavern was used in the monks' kitchen, and it was never found to give to any dish a disagreeable taste or smell." 
Table XIII. (See vol. i., p. 16.)

Order 2. Passerine. Tribe 7. Tenuirostres.

THE birds of this tribe, comprehending the rest of this division, are classed together, not so much with reference to the actual strength or weakness of the bill, as on account of its form and comparative narrowness and length, which is seldom less than twice that of the head, sometimes straight, at other times more or less bent. In other respects, they differ very materially; in fact, they have no connexion whatever with each other. Amongst them we find, of foreigners, the Humming-birds, and the genus Todus, much resembling Kingfishers, but feeding on insects instead of fish. Some species of the rest are British, such as the Hoopoe and Bee-eaters; both of which are, however, very scarce.

In walking through woods, a rapping sort of noise may be frequently heard high up in trees; and though the hearer feels pretty confident that he is within a few yards of the spot from whence this rap, rap, rap, proceeds, he may fail in finding out the cause. But if he has a keen eye, he may at last perceive a small grayish blue-backed bird, with a yellowish breast, busily employed, knocking away with the full force of its head, beak, and body, as if the whole were one solid mass, moving on the hinges of its thigh-bones. After a while, the bird will be seen to glide, rather than climb, up, or round the stem, and disappear-till it is again detected by a repetition of the rap, rap, rap. It is the Nuthatch, in the act of examining trees for insects, or engaged 
in hammering nuts to pieces, which it first adroitly fixes in a crevice of the bark, and when the shell is broken, eats the kernel. Should the nut accidentally fall, it will dart down, and, in most cases, catch it with its claws before it reaches the ground, and replacing it in its chink, resume its work. One, slightly wounded, and caught, was put in a cage, when, without loss of time, it began battering the wood-work, just as it would have done a nut-shell, and persevered till it died, more of fatigue than hunger, for they are bold birds, and feed readily. In America, it is said that they can be tamed, and will creep up and down their owner's body, poking their bills into seams and button-holes, just as they do on trees in their wild state.

The Certhia, or 'Tree-Creeper, like the Nuthatch, glides up and down the stems of trees, but so far from having a bill strong enough to crack a nut, it is so feeble that the shell of a beetle's wing would resist its powers-but it is admirably adapted for its mode of life. The little Tree-Creeper looks more like a mouse than a bird, as it runs in silence up and down a bough in search of minute insects; and so beneficial has it been found in ridding trees of noxious insects, that in America, where it seems to be more abundant than with us, a box is placed at the top of a long pole, to entice it to build in gardens, where it makes itself a very welcome guest.

The Bee-Eaters are so rarely seen in England, as scarcely to be considered as British birds, but when once seen can never be mistaken, or forgotten, brilliant as they are with blue and green of various 
shades, tinged by beautifully reflected lights. As its name implies, it lives chiefly upon bees, which it catches on the wing.

The Hoopoe is another elegant bird, very scarce, but not quite so rare as the Bee-Eater. One was not long ago caught on Salisbury Plain, in a weak and exhausted state; it must have come from a distance, as its beak was filled with red clay, of a quality not found in that neighbourhood. If fatigued from the journey it had performed, the distance must have been very great, for one approached a vessel in the middle of the Atlantic, and kept company with it a good way, but did not settle on board, which it probably would have done had it been tired.

It is common in some parts of the Continent, and by no means wild, for we have seen it on the ground, and on the trees, in a public walk at Seville, but is most abundant in Egypt and Arabia, where they are called the children of Solomon, from a tradition that they formed part of the cargo of the "navy of Tharshish," bringing to him from Ophir "gold and silver, ivory, and apes, and peacocks." I Kings x. 22. It is currently believed by the people of the country, that its crest was then a crown of gold, but that the avidity of mankind for this precious metal occasioning the birds to be often killed for their crowns, they assembled together, and represented their case to Solomon himself. This monarch, in his great wisdom, understood the languages of all animals, as well as of all people, on the face of the earth; and hearing, and pitying their case, he prayed to their Creator to ameliorate their destiny, when the crown 
of gold was instantly changed to a crest of feathers, of equal if not still greater beauty.

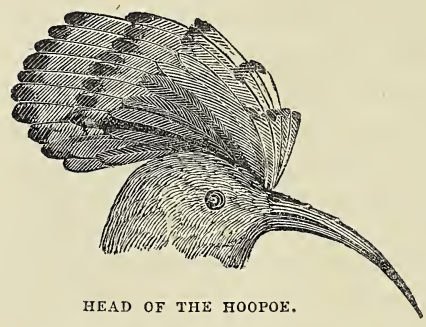

The Kingfisher, rivalling, if not exceeding the Bee-Eater in the blues and greens of its beautiful plumage, is also much more common. Most of our readers may probably have seen it darting in the direction of a brook-course like a flying-emerald. We were once fortunate enough to watch one within. a few yards for some time. It was on a calm sunny day; the bird was observed to settle on the post of a rail, projecting into a piece of water: a boat was gently impelled towards it, in perfect silence; it seemed to take no notice, sitting motionless, as if it had been stuffed and placed there for ornament. In an instant it darted off with so rapid a motion, that a green bright line from the post to a splash of water, where it had plunged, alone marked its course. In another instant, it rose, and with as rapid a flight resumed its position on the post, having swallowed the little fish, whose bright scales we could just see glistening in the sun as the bird emerged from the water. There it rested motionless as be- 
fore, till another plunge denoted the capture of another fish; and so on, till after having captured. four or five, it darted away, and was seen no more.

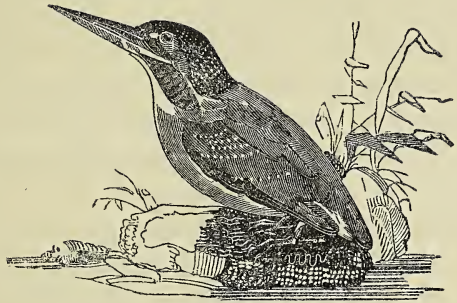

THE KINGTISHER.

Its nest is in great part composed of fish-bones, which it throws up in pellets similar to those cast up by Owls, of which we have already spoken.

The Humming-birds are the last of this tribe we shall notice, lamenting that none but those who cross the seas, and can visit them in their native haunts, will ever be fortunate enough to behold the glorious robes with which nature can invest even the smallest of her works. Truly may it be said of these lovely birds, as of the lilies of the field, "that Solomon in all his glory was not arrayed like one of these."

"Never was I more excited to wonder than by one of these little creatures," says a traveller*, "so much more resembling a splendid shining insect than a bird. It was on a fine day, at the commencement of an American Summer, on the banks of Lake

* Captain Head's Forest Scenes. 
Huron, that I first beheld them. Beautiful birds were drinking and splashing themselves in the water; and gaudy butterflies, of a very large size, were fanning the air with their yellow and black wings. At this moment a little blazing meteor shot like a glowing coal of fire across the glen; and I saw for the first time, with admiration and astonishment, what in a moment I recognised, that resplendent living gem, the Humming-bird! buzzing like a HumbleBee, which it exactly resembled in its flight and sound; like it, it sprang through the air by a series of simultaneous impulses, tracing angle after angle with the velocity of lightning; till poised above its favourite flower, all motion seemed lost in its very intensity, and the humming sound alone certified to the ear the rapid vibration of its wing, by which it supported its little airy form."

They vary from the size of a Humble-Bee to that of a Willow-Wren; the nests of the smaller sort appearing more like mossy knots on a branch than the manufacture of a bird, not exceeding an inch in diameter, and formed of the most delicate materials. They will build fearlessly within sight of a window, where they may be leisurely observed. They frequently assemble in great numbers round some sorts of flowers, yielding those sweet juices, which, together with insects, compose their food. The aloe is one of them. A gentleman in Jamaica thus describes them hovering round a plot of these plants, covering nearly twenty square yards, of which about a dozen were in full bloom. "The spikes, bearing bunches of flowers, were from twelve to fifteen feet high; on each spike were many hundred blossoms of a bright yellow 
colour, each of a tubular shape, and containing its drop of honey. These alone afforded," as he says, " a splendid scene; but the interest was doubled, by the addition of vast numbers of Humming-birds, fluttering round the openings of the flowers, and dipping their bills, first into one floret and then into another, the sun shining bright upon their beautiful plumage, giving them the appearance of, now a ruby, then a topaz, then an emerald, and then all burnished gold."

Delicate and tender as these little creatures are, seeming as if they could not exist for a moment beyond the confines of a sunbeam, they are, nevertheless, scattered very extensively over the whole continent of America; they were found in the desolate regions of the south, near Cape Horn, hovering over the Fuchsia blossoms at Port Famine, and even flying about in snow-storms. In the north, they have been seen in the still more dreary regions of Prince William's Sound, on the same parallel of latitude as the Shetland Islands, to the north of Scotland; and, what is even more extraordinary, they were discovered on the snowy heights of the Orizaba mountains, three times the height of Snowdon above the level of the sea; in all these desolate situations, they seemed as lively as when under the influence of burning sunbeams near the equator. It was in one of these latter situations that Mr. Bullock, who visited Mexico with a view to the natural history of a country then scarcely known, saw how ingeniously these little birds contrived to rob the webs of the spiders of that country of the flies that were entangled in them. They would advance 
beneath the web, and enter the various labyrinths and cells, taking care to make good their retreat, if the spider sallied forth to repel them. In ascending some of the spider's fly-traps, great skill and care were required; sometimes the bird had scarcely room for his little wings to spread, and the least mismanagement would have insnared him in the meshes of the web, and insured his destruction. It was only the outworks of the comparatively small spiders, of about his own size, that the Hummingbird durst attack, as the larger sort rushed out in defence of their property, when the robber would shoot off like a sunbeam, and could be only traced, like an electric spark, by the luminous glow of its refulgent colours.

\section{TABLE XIV. (See vol. i., p. 16.)}

Contains the third order, consisting of birds with two toes before and two behind, for the purpose of climbing. This order is subdivided into two tribes, distinguished by the form and character of their beaks: the cuneiform, or wedge-shaped, being small, and not toothed or indented; and the levirostral or light-beaks, which are indented more or less, and, though in general large, are of a lighter and thinner substance.

\section{Table XV. (See vol. i., p. 17.)}

Order 2. Tribe 1. Cuneinostral, (Wedge-billed.)

OF the five genera included in this tribe, the Cuckoos, Woodpeckers, and Wrynecks, are found in England. The remaining two, viz. Jacamars and 
Anis, are American. The Jacamars are nearly allied to the Kingfishers, living, however, on insects instead of fish, and building on low branches in the depth of dark and damp forests, instead of in holes by the water-side. The Anis, like the Jacamars, frequent the woods, but seem to be of a much more social nature. If taken young, they may be easily tamed, and even taught to speak some words. Amongst themselves, too, they are the most friendly birds imaginable, for they not only fly in flocks, but lay and sit, many pairs together, in one large nest, built by joint consent for the whole party. Future travellers, we doubt not, will be able to relate many interesting anecdotes of these sociable happy birds, but at present little more is known about them than what we have related.

Not so, however, of our British cuneiform birds, our Cuckoos, Woodpeckers, and Wrynecks. Everybody's attention is drawn to the first, whether he will or no. For as soon as Winter is well over, and "April showers prepare the way for May flowers," we hear the Cuckoo's note. It would be difficult to say whether we should call them solitary birds or not. Usually, indeed, one only is seen; but not unfrequently three, four, or even more, will assemble upon a tree, and make the air resound with their well-known notes, uttered sometimes as they remain perched, at others as they quiver through the air with an odd sort of wild fluttering flight. It appears, however, from good evidence, that they either quit their winter-quarters together, or falling in with each other on the journey, land in little flocks. Some years ago, at dawn of day, early in the Spring, 
a gentleman, living on the Cheshire side of the river Mersey, opposite Liverpool, was awakened by a kind of chattering noise, interrupted by the cry of"Cuckoo, cuckoo," in a low plantation near his house, situated amongst the sand-hills, bordering the shores of the estuary, and on looking out, observed a pretty large flock, which, at sun-rise or soon after, all took to flight.

Here, then, we have an instance of their being sociably inclined on their arrival; and it would seem that they are equally so when about to leave us : for in a garden in the county of Down, in Ireland, from the 18th to the 22nd of July, not less than forty Cuckoos were observed, for the most part amongst the gooseberry-bushes, probably collecting the grubs which often infest those plants, and not to eat gooseberrries, as the gardener supposed; and it was remarked that they were almost all so sleepy and dozing, as to permit a very near approach, though not quite so near as to admit of being caught by the hand. There happened to be a late brood of Blackbirds, not quite fledged, in a nest. They were discovered by the Cuckoos, who destroyed all but two; they were seen to tear them in pieces, the gardener actually rescuing one from their grasp, which had its leg and wing severed. Not above three or four were heard to cry "Cuckoo," and then in a sort of hoarse unnatural tone. The greatest number collected towards sun-set, though many remained throughout the day. After the 22nd of July, only one or two remained, which were evidently smaller than the rest, probably the youngest.

Singular as is its cry, so equally singular and 
equally known to all, is that strange unnatural propensity, peculiar to this bird, of leaving to others the care of its young. Why does the Cuckoo do this? Is it because it has no knowledge of building a nest? Far from it, for if it chooses so to do, it can build a nest, and rear its young ones, as well as another; for a clergyman, near Glossop in Derbyshire, not only saw a Cuckoo rise from its nest, built on the stump of a tree, but in it found two young ones; and by way of ascertaining whether they were under the care of the real or foster-parents, he confined one of them to the nest, and for many days saw the old Cuckoo feed it as regularly and tenderly as the poor little bird did its monstrous nursling, which we have already mentioned, vol. i., p. 207.

To this, and a thousand other such marvellous instinncts and habits, we have no answer to give. The why and the wherefore, are yet to be learned. But that He who gave the bird such an apparently unnatural habit, had His reasons for so doing, there can be no doubt, and it is one of the pleasing occupations and pursuits of a naturalist to use all diligence, diving as far as possible into these mysteries, and finding out, as far as he can, why what is apparently wrong may nevertheless be really right, a working together for a good end, and a fulfilment of one great uniform design of Perfection and Wisdom.

In vol. i., p. 207, a curious case was mentioned of a Cuckoo having been fed by a Thrush of its own age. The bird was successfully reared, and continued in good health till about the period at which other birds of its kind were in the habit of leaving the country, when it began to mope, particularly during 
the day; towards night, however, it became more restless and fidgetty, fluttering about and flying up and down the cage. After this, not being able to escape, it recovered its spirits, and was alive and in good health in October, 1832, when the narrative reached us, though it probably died in the course of the winter, the usual fate of numbers which have been kept in a state of confinement. We do not indeed recollect a single well-authenticated instance of one of these birds living for a year, when kept in confinement, which is the more surprising, as their usual insect-food might be generally procured.

To naturalists various other peculiarities in the Cuckoo are well known, but in closing our account, we would refer to two, more particularly worthy of notice, as instances of the wonderful manner in which its wants are assisted by nature. The Cuckoo, as we have said, lays its egg in the nest of a small bird; of course, if this egg were large in proportion to the size of the parent bird, it would be far too large for the little nest in which it was placed, and its unnatural size would moreover, in all probability, frighten the lesser foster-mother, and induce her to desert her own nest; but a Cuckoo's egg is remarkably small, and therefore can be laid, without exciting suspicion, in the midst of others of a naturally small size. In the next place, it is known that the young Cuckoo always contrives to make room for its increasing size, by throwing the other nestlings out of the nest; but were it of the usual form with other birds, it would find great difficulty in accomplishing this. Nature, however, lends a helping-hand, and has given it a remarkable 
depression or hollow, between its shoulders, into which, by an odd sort of jerk, it contrives to lift the young birds, and then shuffling backwards to the edge of the nest, throws them over. This hollow, however, only remains for a certain time, and then fills up; and it is an extraordinary fact, that if the young birds are designedly kept in the nest till the hollow is filled up, the young Cuckoo, as if aware that it has no longer the power to get rid of them, allows them to remain unmolested. 


\section{CHAPTER IV.}

CUNEIROSTRAL CONTINUED. - WOODPECKER - TAME ONE. - WRYNECK - TONGUE OF. - LEVIROSTRAL LIGHT-BILLED.-PARROTS.-TOUCAN.-GALLINACEOUS -POULTRY TRIBE. - PIGEONS, AMERICAN - PRODIGIOUS NUMBERS OF-RAPID FLIGHT-EMPLOYED AS MESSENGERS- MODE OF CATCHING-ATTACHMENTS OF.-COCKS.-PHEASANTS-COURAGE OF.-ON BREEDING PHEASANTS-BOX FOR FEEDING-PRIZED BY ANCIENTS.-TURKIES, WILD-SOCIAL HABITS OF.-PARTRIDGES, TAMED-NESTS OF-VARIOUS SORTS OF.QUAILS - IMMENSE FIIGHTS OF, - BUSTARDS. OSTRICH - NESTS OF - AFFECTION - HUNTING STRENGTH OF.-CASSOWARY AND EMU.

THE Woodpecker is, by sound at least, almost as well known as the Cuckoo. Its noisy, merry, laughing cry may often be heard in the neighbourhood of woods, or issuing from some large tree, to the stem of which, if carefully looked for, the bird may be seen clinging, the head thrown a little back, the weight of the body resting almost entirely upon the tail, the feathers of which are hard and wiry, more like bristles indeed than feathers; and, if examined, these will generally be found much worn at the edges, by being constantly rubbed against the rough bark of trees. It is a shy and solitary bird, but nevertheless some species, at least, can be tamed.

A clergyman, travelling in Turkey, was performing quarantine in a Turkish village, having passed through a district in which the plague was raging. He was confined in a wretched apartment, and had nothing to interest or amuse him during a tedious 
imprisonment, everybody keeping at a distance for fear of infection, when, one morning while at breakfast, a bird of the Woodpecker species, flew in at the window, with, to use his own words, "all the familiarity of an old friend," hopping on the table, and picking up the crumbs and flies. It had belonged to a young girl just buried, and by a singular instinct left the house of the dead, and flew into his room. Its habits were curious, and so familiar that they were quite attractive; it climbed up the wall by any stick or cord near it, devouring flies. It sometimes began at his foot, and at one race would run up his leg or arm, or round his neck, and down his other arm, and so to the table. It would there tap with its bill with a noise as loud as a hammer, and this was its general habit, on the wood-work in every part of the room; when it did so, it would look intently at the place, and dart at any fly or insect it saw running-in all probability adopting this noisy mode of disturbing such insects as might be concealed within, that it might seize them the moment they appeared*.

The Wryneck is a small bird about the size of a Thrush, which comes and goes nearly at the same time as the Cuckoo, whence it is in some places called the Cuckoo's Mate. Its habits and formation in many respects resemble those of the Woodpecker, particularly its tongue, which well deserves examination. On opening the mouth of either of these birds, the tongue appears neither larger nor longer than the usual size, but if taken hold of by the tip, which in.

* Walsh's Constantinople, p. 310.

VOL. II. 
these birds is almost as hard and sharp as a thorn, and drawn out, it will be found to extend to the length of several inches. The use of this remark-

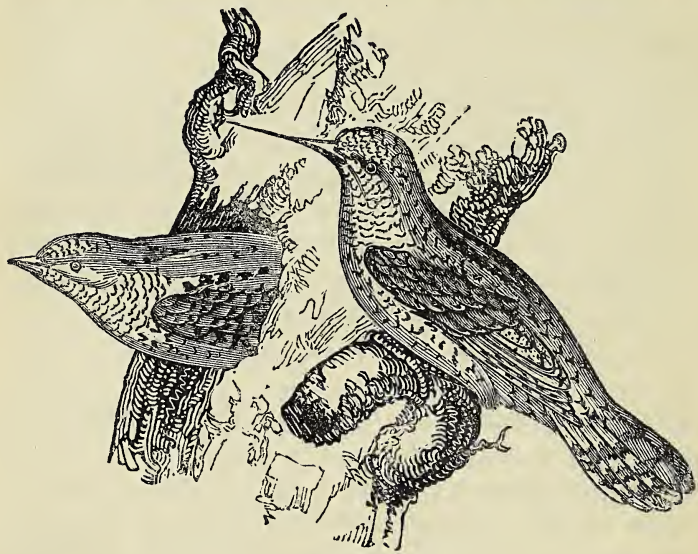

THE WRYNECK.

able instrument is, that by being darted suddenly out, it may transfix, or pin through, any distant insect, which is immediately swallowed, by the bird's having the power of as rapidly drawing it back. The Wryneck, though a migratory bird, may however be kept alive for a longer time than the Cuckoo: we knew an instance of one which lived a year and a half in a cage, and never appeared to show impatience during its confinement; it was observed always to take its food by throwing out its long tongue. 


\section{3}

TABLE XVI. (See vol, i., p. 17.)

Order 3. Tribe 2. Levirostral, (Light-beaked.)

Here we have no less than eight genera of birds, not one of which inhabits our country-and with the exception of the Parrot and Parroquet tribe, (and we may add the Toucan,) are comparatively very little known. We have already noticed the Toucan, and its enormous, though light, beak; indeed, were it heavy in proportion to its size, the poor bird would find it a sad inconvenience, not only preventing its flight, but actually weighing its head down to the ground. As for Parrots, we, who are accustomed to prize them as valuable and scarce birds, are little aware of the actual plague they are in their own country. Nothing can be more beautiful, certainly, in description and appearance, than a flight of these brightly-feathered birds; but the husbandman, who sees them hastening through the air, with loud and impatient screams, towards his crops, looks upon them with dismay and detestation, knowing, that the produce of his labour and industry is in jeopardy, when visited by such a voracious multitude of pilferers, who, like the locusts of Egypt, desolate whole tracts of country by their unsparing ravages. 


\section{4}

TABLE XVII. (See vol. i., p. 18.)

Order 4. Galminaceous, (or Poultry tribe.)

We now come to one of the most useful divisions of birds, forming in their domesticated state no inconsiderable source of profit to those who rear them for the purpose of sale.

In the tables of classification, this Order comprises three tribes:-1st, Pigeons; 2nd, Fowls or common poultry; and 3rd, the short-winged families of Ostriches, Cassowaries, \&c., which by others have been classed amongst the Waders, in consequence of their length of legs.

In this country, where Pigeons are, generally speaking, a domestic bird, few persons have an idea of their countless increase and abundance, when left to themselves, roaming over wide tracts, and following, almost without interruption, their natural habits. Even in our dove-cots, however, their increase is often prodigious; it having been found, that in the course of four years, nearly 15,000 have been produced from a single pair. Bearing this in mind, the reader will be better prepared to credit the startling accounts of the myriads of these birds, so often witnessed in North America, consisting of a particular species called the Passenger, or Migratory Pigeon, from their regular visits to certain districts, either for the purpose of feeding, or rearing their young. And though thousands and tens of thousands are destroyed, chiefly at their roosting-places, the numbers seem rather to increase than diminish. Such multitudes 
had never before been witnessed as in 1829 . Flocks extending miles in length, were, for days together, seen passing over the hills during the Spring, from the southward; the mighty mass collecting in an encampment in a forest, upwards of nine miles in

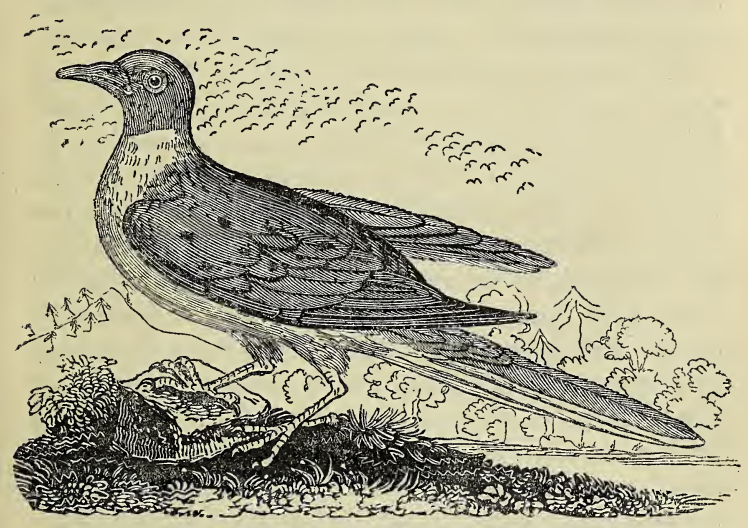

THE PASSENGER OR MIGRATORY PIGEON.

length, and four in breadth, in which there was scarcely a tree, large or small, which was not loaded with their nests. In those parts of England frequented by our common Wood-Pigeons, the wellknown rustling and rattling of a host of wings, as a cloud of them rise from some favourite haunt in a wood, will not easily be forgotten; but this clattering of flapping pinions, is nothing when compared to the uprising of these American flights, which is described as an absolute and constant roaring, so loud and overpowering, that persons on 
approaching the wood, can with difficulty hear each other speak. Amidst these scenes of apparent bustle and confusion, there reigns, notwithstanding, the most perfect regularity and order. The old ones take their turns regularly in feeding their young; and when any of them are killed upon their nests, others immediately supply their places.

It has been said, that they only lay one egg at a time, but this is not strictly true, many of them laying two. But even at this rate, it would be difficult to account for their vast numbers, without the further knowledge of their prolific nature, and the rapid growth of the young birds. Their sittings are renewed, or rather continued; one pair having been thus known to produce seven, and another, eight times in one year. In twenty-three days from the laying of the egg, the young ones could fly, being completely feathered on the eighth day. When the broods are matured, with the exception of, probably, some tons of the young, which are killed, and carried off by actual waggon-loads, being more esteemed for food than the old ones, they continue their course towards the north; from whence, in December, they return in the same dense mass, and are usually found to be remarkably fat: proving, that in the northern regions they find an ample supply of food; and vast, indeed, must be the stock, to furnish and fatten such a swarm of hungry mouths. In the crop of one of our common English Wood-Pigeons, just killed, we found upwards of an ounce of the fresh-budding leaves of clover, and in another, mentioned by Mr. White, of Selborne, was found an equal quantity of tender turnip-tops, so nice 
and inviting, that the wife of the person who shot it, boiled and ate them, as a delicate dish of greens, for supper. The consumption of grains of wheat by a common House-Pigeon, we found to amount to two ounces in twenty-four hours, and in the following twenty-four hours, when fed with peas, it consumed about the same weight. Hence we may easily form some idea of the enormous consumption of a large flight. Supposing one Pigeon to feed regularly at the above rate, its annual average supply would amount to about fifty pounds in weight,-a serious consumption of grain when large numbers are concerned. The following calculation, made by a very accurate observer, places the subject, as far as relates to the American Wood-pigeons, in a still more striking point of view. He saw a column of Pigeons one mile in breadth, moving at the rate of one mile a minute, which, as it was four hours in passing, made its whole length 240 miles. He then calculated that each square yard of this moving body contained three Pigeons, which thus gave two thousand, two hundred and thirty millions, two hundred and seventy-two thousand Pigeons! and yet this he considered to be less than the real number. Computing each of these to consume half a pint of seed daily, the whole quantity would equal seventeen millions, four hundred and twenty-four thousand bushels per day. Heaven, he adds, has wisely and graciously given to these birds, rapidity of flight, and a disposition to range over vast uncultivated tracts of the earth, otherwise they must have perished in the districts where they resided, or devoured the whole productions of agriculture, as well as those of the forests. 
When noticing the flight of birds, the rapidity of these, and of our trained Carrier-Pigeons, was alluded to * The Passenger-Pigeon is particularly adapted for speed, having a light active body, furnished with long wings, in which the first quillfeather is equal in length to the rest, a sure indication of that rapid and long-continued flight which they are known to possess. This faculty, in addition to the possibility of training that particular species, the Carriers, to return without deviation or delay to places from whence they had been removed, was, from very early days, turned to good account. We learn from an ancient historian, Diodorus Siculus, that, above two thousand years ago, they were used as conveyers of intelligence, and about five hundred years ago, relays of Carrier-Pigeons formed part of a telegraphic system, adopted by the Turks. Regular chains of posts were established, consisting of high towers between thirty and forty miles asunder, provided with Pigeons, and sentinels stood there, constantly on the watch, to secure the intelligence communicated by the birds as they arrived, and to pass it on by means of others. The note was written on a thin slip of paper, enclosed in a very small gold-box, almost as thin as the paper itself, suspended to the neck of the bird; the hour of arrival and departure were marked at each successive tower, and for greater security, a duplicate was always despatched two hours after the first. The despatches were, however, not always enclosed in gold, but merely in paper; in which case, to prevent 
the letters being defaced by damp, the legs of the Pigeons were first bathed in vinegar, with a view to keep them cool, so that they might not settle to drink, or wash themselves on the way, which in that hot climate they were often doing.

Of late years, the number of wild Pigeons in England, is, like the Swallows and Starlings, evidently diminishing, and it is rare to see a flock of any magnitude; but formerly they were very abundant, as we may learn, not only from incidental remarks in ancient writers, but from allusions to the particular manner of catching them. Thus we find the prophet Isaiah speaking of them, "flying as a cloud ;" and constant allusions are made to their prodigious numbers. Indeed, had they not been far more numerous than they are at present, it would not have been worth while to have adopted the expensive mode of catching them, which we believe is at present entirely given up, though till within a few years it was practised near Cava, on the Gulf of Sorento, in Italy, where, upon the tops of some bushy hills, were erected small circular towers; on each of these, towards the latter end of September, a man posted himself, and as soon as a flight of Pigeons passed on their way through the valley, he flung a flat stone over them, which, by its form or manner of throwing, made a sort of whistling noise, which frightened the birds, and hastened their flight towards a place of refuge. Another was thrown from each tower as they passed, until the affrighted flock was thus driven to the last turret in the valley, where a large net was spread in the hollows amongst the bushes, in which the birds were taken. Great art was requisite in 
throwing the stone, as upon this the success of the diversion depended.

At a small village called Gerde, about a league from Bagnère de Bigorres, in the Pyrenees, a mode somewhat similar is adopted, from the middle of September to the middle of November, which attracts the notice, and is resorted to, as a favourite amusement by those who visit that beautiful country. Large nets are stretched across the end of a narrow valley, and made fast to trees. Three tall spars, nearly fifty feet in height, are reared in a triangular form, meeting in a point at the summit, where a sort of nest of bushes is made, in which a person conceals himself, ascending the high poles by small pegs, which, as they shake under his weight, and are as slender as possible, consistently with strength, appears to lookers on, to be a service of no small risk. Two men are also concealed in bushes near the nets, which, by means of lines, they are enabled to throw over the Pigeons as they advance; while others, assembled on the heights immediately above, frighten the birds, and force them to fly downwards as they pass through the channel of the valley. When all have taken their positions, they wait patiently and silently the arrival of a flock of Pigeons. Their approach is announced by a rushing sound, on hearing which, the people on the heights pour upon them a volley of short sticks, which compel them to lower their flight towards the ground, when, if they attempt to rise, the man in the nest immediately begins shaking his airy perch as much as possible, and throwing upon the affrighted birds, sticks tied together in the form of a cross, which make a whiz- 
zing sound as they fall. Impelled by this united attack, the Pigeons rush forward to the head of the gorge, and there meet their fate in the nets, which stop their progress. By this means sometimes as many as two hundred are caught at once.

The American wild Pigeons, as well as our common Wood-Pigeons (Columba anas, and palumba), the Stock Dove and Ring Dove, usually build in trees; but not always, for in many situations, they prefer holes in rocks and precipices, and even, in some cases, old rabbit-burrows; when found in these, the warreners fix sticks at the mouth of the hole, in such a manner as to prevent the escape of the young birds, but wide enough apart to allow the old ones to feed them. In the eastern countries and the Holy Land, the wild Pigeons almost invariably.prefer such situations to trees, thus confirming the words of the prophet, who speaks of the Dove that maketh her nest in the sides of the hole's mouth.-Jeremiah xlviii. 28.

It is remarkable that, although our common WoodPigeon is supposed to be the origin of all our common House-Pigeons, every attempt at taming the young of these birds has failed; no sooner are they released from confinement, notwithstanding every attention and care, than they fly off at once to their native woods, and return no more; but the Indians of North America seem to have found out some method of changing their nature, as a traveller found wild Pigeons amongst a tribe of Indians, which were so tame, as to fly and return again.

That birds of this species can form odd attachments, we may learn from the following strange as- 
sociation between a House-Pigeon and a cat. The Pigeon had made her nest in a loft much infested with rats, which had more than once destroyed her eggs, or devoured her young ones. Her repeated losses at length induced her to rebuild her nest in another part of the loft, where a cat was rearing three kittens, with whom she contrived to form a strong friendship. They fed from the same dish, and when the cat went out into the field, the Pigeon was often observed to be fluttering near her. The Pigeon, aware of the advantage of her protection, had placed her nest close to the straw bed of the cat; and there, in safety, reared two broods of young ones. And in return for the protection she experienced from the cat, she became a defender of the young kittens, and would often attack, with beak and wings, any person approaching too near.

Considering their insignificant means of defence, consisting, in great measure, of the spur on the leg of the male, few birds exhibit a more bold and resolute spirit than the poultry tribe, in which we may include Pheasants, so nearly are they allied to our common barn-door fowls, in their habits and mode of life. We knew an instance where a barn-door Cock became the terror of his little domain; accustomed to be fed by his owner, a clergyman, he shortly began to express his disappointment by very determined attacks, if his master happened to pass him without the accustomed offering. On one occasion he actually struck a piece out of a strong kerseymere gaiter, and repeated the attack, in spite of some severe kicks which it was found necessary to inflict in selfdefence. Nothing daunted, though occasionally fairly 
kicked several yards, like a foot-ball, he would still come on as fiercely as ever, for three or four times.

During one of these assaults, he received an injury, which lamed him for a week; but no sooner had he recovered than he became as pugnacious as ever. His reasoning, too, appeared to be on a par with his courage, for he soon discovered that women were protected by the lower part of their dress, and accordingly, instead of flying at their legs and feet, he invariably flew at their heads, fixing himself on their shoulders. To such a degree did he carry on this warfare, that the female who had charge of feeding the fowls, and had been accustomed to poultry all her life, never ventured into the yard without some weapon of defence. His offensive operations were carried on with such persevering spirit, that for fear of his doing some serious injury, particularly to children, it was at last found necessary to destroy him.

This boldness is not always confined to the domestic tenants of the farm-yard. The following instances prove that even the wild Pheasant of the woods, and the still more shy and solitary Bustard of the plains, can occasionally lay aside their fear of the human race, and fight as fierce a battle as this Game Cock.

A young lady walking alone, a few miles from Stirling, observed a beautiful cock Pheasant, perched on a stone by the road side. Instead of showing timidity at her approach, he flew down upon her, and with spurs and beak began a furious assault. Being closely pursued, and seeing no way of escape from the enraged bird, she adopted the only alternative that was left, namely, of seizing her adversary, 
whom she carried home, but soon afterwards released; on the door being opened, however, he went out without any sign of fear, and, with a deliberate step, paced backwards and forwards in front of the house, and manifested an inclination to join the fowls in the poultry-yard. It should be remarked, that the young lady, when attacked, wore a scarlet mantle, which probably excited the irritability of the Pheasant, as it is well known to do that of the Turkeycock, and some other animals.

The case of the Bustard occurred some years ago, on Tilshead downs, in Wiltshire, in the month of June, to a man, who was going along the road on horseback, about four o'clock in the morning. His attention was first turned to a large bird flying above his head, which proved to be a Bustard, though till then he had scarcely ever heard of such a bird. He had not proceeded far, before it alighted on the ground immediately in front of the horse, which it soon showed signs of attacking, and in a few seconds began the onset. The rider dismounted with all speed, and, getting hold of the Bustard, endeavoured to secure it, in which, after a long and severe struggle, he succeeded, and carried it to the house of the person to whom he was going, where it was confined. During the first week, it was not known to eat anything; but finally, it became very tame, and would take food from the hands of those accustomed to feed it, though it still continued shy in the presence of strangers. From the time of its capture in June, till August, when it was sold to a nobleman for thirty-one guineas, it was never seen to drink; indeed, after the first three weeks, water was never 
given to it. A second instance of one of these birds attacking a human being, occurred about a fortnight afterwards near the same spot, and under circumstances very similar. The horse, however, took fright, became unmanageable at so unexpected an attack, and ran away with his rider.

In the above cases, we find only an increase of that spirit with which Nature has endowed them; but the clergyman, who possessed the pugnacious cock just mentioned, had a hen, which so far overcame its natural fear of water, as to be in the constant habit of making a short cut from the churchyard (into which she, with the rest of the poultry, occasionally wandered) to the barn-yard, by regularly swimming across a pool, which was situated between it and the church-yard. The distance was about thirty yards, and the part of the pool where she crossed, was so near the end of it, that the other fowls, which came round, arrived before her. This hen had another uncommon propensity, that of catching mice, a practice she pursued with the greatest eagerness, and when caught, she was seen to run off with them; whether she ate them or not, was never known with certainty; at all events, she did not do so invariably, as they were sometimes found dead, up and down the yard.

It has been often doubted whether the Pheasant will breed with the common hen; but the following account from a highly-respectable authority*, seems to set the question at rest, and deserves the attention of those who are interested in the improvement of their race of poultry.

* Quarterly Journal of Agriculture, No. V. 
In the Autumn of 1826, a wandering Pheasant made its appearance in a small valley of the Grampians, the first of the species ever noticed so far north in that part of the country. For some time, it was only occasionally observed, and its presence actually doubted; Winter wants, however, brought it more frequently into notice; and in due season, more unequivocal proofs became apparent. For when the chicken broods of common poultry came forth, and approached to maturity, no small admiration was excited by certain stately, long-tailed, game-looking birds standing forth amongst them, and continuing to grow in size and beauty, until all doubts of direct relationship with the Pheasant effectually vanished. These hybrids partook largely of the character of the parent stranger, and, as they were found to grow to a good size, and possess hardy constitutions, a useful and agreeable variety for the poultry-yards was secured, in a thus simple and unlooked-for manner.

Pheasants are not what is termed indigenous in this country, that is, originally produced or bred here; but were imported from the Eastern countries, to which they are chiefly confined. Their short wings and heavy bodies are little calculated for long flights, which may, in a great measure, account for their remaining so long in one particular part of the world, and explain the cause why none have yet been found in America. But as they are very plentiful layers, - a pair belonging to a gentleman near Dover having been known, in one season, to lay the extraordinary number of one hundred and eightythree eggs, and may, with proper attention, be easily 
reared, we see no reason why they may not be successfully introduced, and abundantly supply any country in the world.

The following directions for rearing them under hens, have been, we know, adopted with success. A sufficient number of eggs being provided, put them under a hen that has kept her nest for three or four days; and if two or three hens happen to sit on the same day, an opportunity will be afforded of shifting the good eggs. At the end of ten or twelve days, examine, and throw away those that are bad, and set the same hen or hens again, if sitting hens should be numerous. The hens having set their full time, such of the young Pheasants as are already hatched, must be put into a basket with a piece of flannel, till the hen has done hatching. Then place the whole brood under a frame, with a net over it, and a covered place for the hen, so as to confine her, but leave the young Pheasants at liberty to leave or return to her at pleasure. Their food must consist of boiled eggs cut small, boiled milk and bread, alum curd, and ants' eggs, - a little of each, and often. Rice may be also given, softened by boiling, and instead of ants' eggs, which in some places are not easily procured, or, in addition to them, maggots from decayed flesh may be used. Artificial ants' eggs may be easily made, composed of flour, beaten up with an egg and shell together, and the pellets rubbed between the fingers to a proper size.

After two or three days, they will be acquainted with the call of their foster-mother, and they may then be allowed to run upon a grass-plot, or elsewhere; the edge of a corn-field is very desirable, 
as they like the tall stems, and soon learn to pick up the green grains, - taking care to shift them with the sun, and guard them from cold winds. They ought not to be released in the morning before the sun is up, and they must be shut in with the hen in good time in the evening. When they are old enough, those that are to be turned out wild ought to be taught to perch. This is done by tying a string to the hen's leg, and obliging her to sit in a tree all night. She should be placed there before sunset, and if she falls down, she must be perseveringly replaced, till she become contented with her situation; then the young birds will follow the hen, and perch with her, and in a few days will shift for themselves. If regularly fed, they will remain near any particular spot, and frequent a lawn or pleasureground as familiarly, and almost as fearlessly, as common poultry. An ingenious feeding-machine has been made, by which the grain may not only be kept

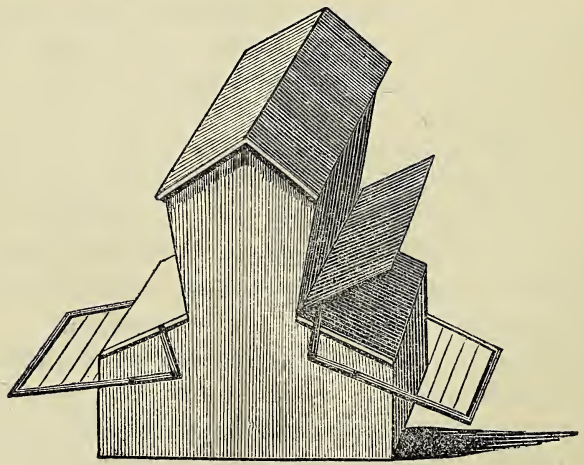

BOX FOR FEEDING PHEASANTS. 
dry, but reserved for the sole use of the Pheasants, or at least, the larger sort of fowls, as the lid, covering a trough containing the seed, opens and shuts by the weight of the Pheasant hopping on or off a perch connected with a crank.

Pheasants have been considered, and with some reason, foolish birds, easily taken by every variety of snare; but, together with the Peacocks, they were, nevertheless, probably on account of their beauty, not only highly-esteemed in ancient times, but viewed with a sort of superstitious respect; so much so, that, by the heathen Romans, those who first served them up at entertainments, were deemed guilty of a sort of impiety to their idol-gods; and even when they were afterwards introduced as food, they were never used, even by the emperors, except on the most solemn occasions. In after-times, the Christians, who too often adopted the customs of their heathenish predecessors, paid an almost equal respect to these birds. Thus we find so serious a writer as St. Jerome, giving directions for boiling a Pheasant, so that the form of the bird might be completely preserved. From the table, Pheasants and Peacocks became most fashionable and honoured additions to the toilet; historians telling us, that the most splendid present one of the Popes sent to Pepin, one of the earliest kings of France, was a mantle, embroidered with the feathers of the latter; and the richest furniture in the apartments of the nobles in the middle ages, was painted or inlaid in such a manner as to represent a Peacock's tail, spread out and studded with eyes.

At table, they were never introduced, except on 
the most important and magnificent occasions; and he who carved them was considered as honoured in the highest degree. The feathers from the tail of the Peacock were formed by the ladies of quality into a crown, for the purpose of decorating their favourite troubadours, or minstrels. The eyes were considered to represent the attention of the whole world as fixed upon them. And in those days of chivalry, so constantly was the Peacock the object of the solemn vows of the knights, that its image was hung up in the place where they exercised themselves in the management of their horses and weapons; and before it, when roasted and dressed in its plumage, and placed, with great pomp and ceremony, as the top dish at the most splendid feasts, all the guests, male and female, took a solemn vow. The knights vowing bravery,-the ladies engaging to be loving and faithful. It was, no doubt, in consequence of this reneration, that queen Elizabeth chose to have her picture taken in a gorgeous robe covered with Peacocks' eyes.

If we are indebted to India for the Peacock (where, in their wild state, they fly in coveys, glittering in the sun, or may be seen roosting in trees, in such numbers, that an author describes them as almost hiding the foliage with their plumage), and to the Eastern countries for our Pheasants, we have to thank the New World for that more homely, but more useful bird, the Turkey, which, there is reason to believe, was never known in Europe, till about three hundred years ago, when it was imported from America; but which has now been so widely spread, that in some places, as, for instance, in the 
neighbourhood of the Black Sea*, they have nearly returned to their originally wild state; and near Smyrna, such immense flocks of Turkeys approach in the depth of winter, that a traveller speaks of purchasing four of the largest size for about five shillings.

From the journals of travellers in the interior of New Holland, we learn that a species of wild Turkey is, in some places, very abundant; the bird has been described as resembling our Bustard, and is remarkably shy. We have heard, from a highlyrespectable naturalist, of a singular instinct in their mode of building their nests and hatching their young. It is said, they collect a mass of fallen leaves together, forming a considerable pile, in the middle of which the eggs are deposited; from the particular character of the trees usually found in that country, the leaves are full of moisture, consequently, when collected, they soon heat, and the sagacious bird ascertains by some instinctive signs, the period when the heat of the mass of leaves has continued long enough to hatch the eggs, when the old ones pull the heap to pieces, and, releasing the broods, lead them off to the woods or plains.

In their native wilds of North America, they herd together in considerable flocks, but, like the original inhabitants of the country, the poor Indians, they are every year becoming more scarce; driven from their accustomed haunts by those who have taken possession of their land. Partial as these birds are to Indian corn and buck-wheat, they are very destructive visiters, and the farmers, with reason,

* See Clarke's Travels, vol. ii. 
dread their approach, as fearful devourers of their crops.

Though on the whole, friendly and sociable birds, and fond of travelling together in flocks, a good deal of severe discipline is exercised by the old birds, particularly the males, who seem to rule over the juniors with a very strong hand. The young males, called Gobblers, are compelled to live by themselves; for if they venture to approach their seniors, they are sure of being severely punished; and many are killed on the spot by repeated blows on the skull. They frequently meet with great difficulties in their journeyings, in consequence of rivers stopping their progress. In this case, they seem to hold a council; the old males strut about, and gobble loudly, while the hens and young males spread out their tails, and make the most of their figures. At last, as if by common consent, they mount the highest trees, from whence, at a particular signal from a leader, away they launch themselves. If, as is often the case, the river is wide, these short-winged, heavy-bodied travellers perish in great numbers. The strong, old, and healthy, generally accomplish their object, while the weak and tender, falling short, are hurried down the stream; but they do not, in this perilous predicament, lose their presence of mind,-for, spreading out their tails as a sail, they close their wings, stretch out their necks, and strike out boldly for the shore.

There can be no doubt that our European stocks of tame Turkeys are descendants of these wlid Americans, and yet it is remarkable that, train and keep them as long as you please, the wild Turkey 
will still retain its original habits; and it is not improbable, that, if left to themselves, the descendants of our tame ones would in time resume the wild habits of their forefathers, like those which we have above mentioned, abounding near the Black Sea.

We are not, indeed, without instances of wild Turkeys, at this day, in our own country, and a curious anecdote has reached us of a friendship taking place between a flock of these birds and a Partridge. It occurred at Tyninghame in Scotland, where there is a breed of Turkeys, which never enter into the poultry-house or yard, but roost in the trees, and live chiefly on beech-mast, and anything else they can pick up, though they are tame enough to come about the house to be fed,in the time of frostand snow. About eight or ten years ago, a cock Partridge, full grown, suddenly joined himself to the flock of these Turkeys, and remained with them constantly during the whole Summer, Autumn, and Winter; at night he slept under the trees in which they roosted; in the day he fed with them, and was not the least frightened or disturbed by people walking among them. He took great liberties with the old Turkeycock; when he saw him going to pick up a worm or any seed, he used to run under him between his legs, and snatch it out of his mouth, the Turkeycock never resenting the indignity. Early in the Spring he left them, as it was supposed, to find himself a mate for the pairing-season. But, in the beginning of Autumn, he rejoined his old friends, and continued with them as formerly until the next 
pairing-time, when he again disappeared, but returned no more, having probably been killed *.

Male birds of the gallinaceous or poultry tribe, which associate with a plurality of females, are in general less attached to the young birds of their species than others, which pair and confine themselves to one mate. The following is, however, a curious instance that this insensibility is not invariably the case.

In May, a Turkey-hen was sitting upon eggs, and as the cock in his solitude began to be uneasy and appear dejected, he was allowed to remain in the same space along with her. He immediately, on being admitted, sat down by the hen, and it was at first supposed that this was a mere mark of affection, - but it was soon found that he had taken some of the eggs from under her, which he carefully covered with his own body. The maid who looked after the poultry, thought this mode of hatching would be attended with little advantage, and therefore put the eggs back again under the hen; but the cock was no sooner at liberty than he again carried some of them away as before. The owner, when he observed this, resolved, for the sake of experiment, to let the cock have his own way, and caused a nest to be prepared with as many eggs as its large body was able to cover. The cock seemed to be highly pleased with this mark of confidence, sat with great patience on the eggs, and was so attentive to the care of hatching them, that he scarcely took time to go in search of food. At the expiration of the usual time, twenty-

* Edin. Phil. Journ., No. viii. 
eight young ones were produced; and the cock, who was now in some measure the parent of this numerous offspring, appeared a good deal perplexed, when he saw so many little animals pecking around him, and requiring his constant vigilance; they were therefore removed, from a fear that he might tread upon or neglect them.

Generally speaking, the Partridge is a much shyer bird than the Pheasant, and though we have found it, in the above case, quitting its own species to live with another, it can seldom be induced to lay aside its natural habits and become quite tame. Occasionally, however, by great care, they have been known to attach themselves to man.

In a clergyman's family, one was reared, which became so familiar that it would attend the parlour at breakfast, and other times, and would afterwards stretch itself before the fire, seeming to enjoy the warmth, as if it were in its natural bask on a sunny bank. The dogs of the house never molested it, but, unfortunately, it one day fell under the paws of a strange cat, and was killed.

The Partridge, as is well known, usually builds in corn-fields, where, undisturbed amidst a forest of tall wheat-stems, it rears its brood. Like other birds, it -sometimes, however, chooses a very different sort of nursery, as, for instance, a hay-stack, on the top of which a nest was once formed, the covey hatched, and safely carried off.

In England we have but one sort, but in France, and other parts of Europe, they have beautiful varieties,-the red-legged, Barbary Partridges, \&c.; and in America, there are, again, other sorts, peculiar to 
the New World. We shall give Captain Head's lively description of two varieties, the larch and spruce Partridges, which he met with in his expedition into the interior, near Lake Huron.

"Early in the Spring," he says, "they make their appearance in the pine-woods, welcomed by the solitary back-settlers, not only as harbingers of returning warmth, but as an agreeable addition to their stock of provisions, and a source of amusement. At first, when the snow still covers the ground, they are easily tracked, though by no means easily discovered in the trees, on which these two species invariably perch. They run for a considerable distance from their pursuers, before they rise, turning backwards and forwards, and round and round, twisting about the trees in such a manner as to make it difficult to follow up the foot-marks, and but for the assistance of dogs familiar with the sport, the keenest eye is often foiled." Captain Head thus describes his first meeting with one of these birds:-

"The snow in the woods was crisp from the night's frost, and the sun was just rising in a clear sky, when the marks of game attracted my notice, and my spaniel at the same time evinced the most eager interest and curiosity in the pursuit, quartering the ground from right to left. After walking about half an hour, he suddenly quested, and on going up to him, I found him at the edge of a swamp, among a clump of white cedar-trees, to one of which he had evidently tracked some description of bird; for he was looking steadfastly up into the tree, and barking with the utmost eagerness. I looked attentively, but nothing whatever could I discover. I 
walked round the tree, and round again, then observed the dog, whose eyes were, evidently, directly fixed upon the object itself, and still was I disappointed in perceiving nothing. In the mean time, the dog, working himself up to a pitch of impatience and violence, tore with his paws the trunk of the tree, and bit the rotten sticks and bark, jumping and springing up at intervals towards the game; and five minutes had at least elapsed in this manner, when all at once I saw the eye of the bird. There it sat, or rather stood, just where Rover pointed, in an attitude so perfectly still and fixed, with an outstretched neck, and a body drawn out to such an unnatural length, that twenty times must I have overlooked it, mistaking it for a dead branch, which it most closely resembled. It was about twenty feet from the ground, on a bough, and sat eight or ten feet from the body of the tree. I shot it, and in the course of the morning killed four more, which I came upon much in the same way as I did upon the first. At one of these my gun flashed three times without its attempting to move; after which I drew the charge, loaded again, and killed it. The dog all the time was barking and baying with the greatest perseverance. There is, in fact, no limit to the stupidity of these creatures; and it is by no no means unusual, on finding a whole covey on a tree in the Autumn, to begin by shooting the bird which happens to sit lowest, and then to drop the one above him, and so on till all are killed*."

Very different, indeed, from our straggling covies, are the assemblages of these birds in America.

* Captain Head's Forest Scenery. 
Near Fort Churchill, on the shores of Hudson's Bay, in the Winter season, they may be seen by thousands, feeding on the willow-tops peeping above the surface of the snow. The crew of a vessel wintering there, killed one thousand eight hundred dozen in the course of the season. They are provided with a plumage well calculated for the severe weather to which they are exposed, each feather being in a manner doubled, so as to give additional warmth. Our British Partridges huddle together in the stubbles, but these birds shelter and roost by burrowing under the snow; in the snow, too, they practise a common mode of escaping observation and pursuit, as they will dive under it as a duck does in water, and rise at a considerable distance. The Indians, as well as European settlers, catch them in great abundance, in traps, and live upon them throughout their long winter.

From the earliest ages, partridges seem, indeed, to have been a favourite food, and the pursuit of them as favourite an amusement. In the Scriptures, "to hunt the Partridge on the mountains," is alluded to, as a well-known sport, and to this day, though not exactly with the same weapon, it is practised by the Arabs of Mount Lebanon. They make a slight square-frame of wood, of about five feet in height, over which they stretch an ox-hide perforated in three or four places. The ox-hide is moved quietly, in an upright position, along the ground, and the Arab, concealing himself behind it, is hidden from the view of the game, which unsuspectingly allow the sportsman to come within shot of them. - The Arab, seeing through one of the apertures, quietly 
protrudes the muzzle of his long musket through another hole, and firing upon the birds, as they feed in covies upon the ground, kills a great many of them*.

Our limits will not allow us to dwell much longer on this family of birds, which includes Quails; but we cannot leave them without showing how strongly modern travellers corroborate the account given in the Scriptures, of the prodigious numbers of Quails, and the mode of drying them for food.

"And there went forth a wind from the Lord, and brought Quails from the sea, and let them fall by the camp, as it were a day's journey on this side, and as it were a day's journey on the other side, round about the camp, and as it were two cubits high upon the face of the earth. And the people stood up all that day, and all that night, and all the next day, and they gathered the Quails; he that gathered least gathered ten homers; and they spread them all abroad for themselves round about the camp."-Numbers, xi. 3 I, 32 .

Their coming with the wind, their immense quantities, covering a circle of thirty or forty miles, and being spread in the sun for drying, appeared so impossible to one of our most learned commentators on the Biblet, that he was persuaded our translation was incorrect, and that instead of Quails, locusts were meant. Here, however, we have the evidence of eye-witnesses. " $\$$ Near Constantinople, in the Autumn, the sun is often nearly obscured by the pro-

* Franklin's Constantinople, vol. ii.

+ Bishop Patrick.

‡ Stade's Travels in Turkey, vol. i. 
digious flights of Quails, which alight on the coasts of the Black Sea, near the Bosphorus, and are caught by means of nets spread on high poles, planted along the cliff, some yards from its edge, against which, the birds, exhausted by their passage over the sea, strike themselves and fall. In October, 1829 , the Sultan sent orders to one of his admirals to catch four hundred dozen. In three days they were collected, and brought to him alive in small cages. Another traveller* tell us, that they visit Egypt in immense flights about harvest-time, where the Arabs take them by thousands, in nets. They fly, he adds, in a direct line from north to south, and very rarely from east to west. With respect to their being dried in the sun for food, we have equally good evidence from a third travellert, a foreigner, whose words we will therefore translate. There is, says he, a small island off the coast of Egypt, where these birds usually alight in the Autumn, on which they are taken in such quantities, that, after having been stripped of their feathers, and dried in the burning sands for about a quarter of an hour, they are worth but one penny a pound. The crews of those vessels, which in that season lie in the adjacent harbour, have no other food allowed them. The object of the Israelites, therefore, in spreading them round the camp, was to dry them: a mode of preparing fish and camels' flesh, still practised by the Arabs in the very same country.

The only difficulty seems to be in their being so

* Maddeu, vol. ii.

$\uparrow$ Maillet. 
thickly strewed as to form a solid mass of " two cubits from the face of the earth." But Josephus, who must be allowed to be a better judge of the meaning of words in the Scripture than we can be, and more conversant with the subject on which he writes, explains the passage by saying that it merely meant, that the Quails flew within reach of the Israelites, about two cubits above the ground, which they, in fact, often do when exhausted, and are knocked down by the Arabs with sticks.

The Quail is the smallest of the poultry tribe, but there is one more to be mentioned, forming the connecting link between this and the last of the gallinaceous order, by far the largest of the family. We mean the Bustard, of whose courage in attacking a man and horse we have already spoken*. The Bustard can fly; but its usual motion is on foot, running with such speed as often to rival a greyhound. Formerly they were common on our plains, and in the open country of England; but as enclosures have taken place, they have gradually disappeared, and are now supposed to be, in this country, an extinct species.

One great peculiarity deserves mentioning, namely, a singular pouch, which they have large enough to hold upwards of a quart of water. Its use has not been ascertained; by many it was supposed to be a provision of nature, for supplying them with water, living as they did in vast plains, where water was not common; but as it is confined to the male, this supposition seems to be erroneous, unless, when the female is confined to her nest, her mate provides her with water from this reservoir. 


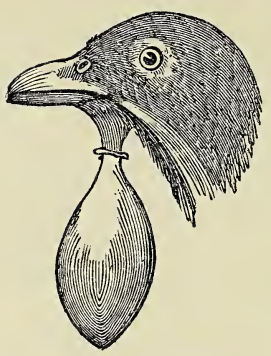

POUCH OF THE BUSTARD.

We come now to the last tribe in the gallinaceous order, consisting of birds altogether foreign, of very peculiar habits: these, as far as wings and flight are concerned, having scarcely a right to be classed amongst birds, as they never quit the ground, and know nothing of the power possessed by others of the feathered race, of soaring aloft, and fleeing away like the Dove, should they wish to seek for food, or repose, in a distant country. These birds are the Ostrich, the Emu, or the Cassowary, and one or two others little known.

Of these the Ostrich is the most common: its beautiful light plumes have long been used as ornaments in ladies' head-dresses; and to this probably, as it was diligently sought after as a valuable prize to the captor, we are indebted for all we know of its natural history, though still much remains unknown, for no bird has been more misrepresented ; first, as a parent, who, after laying her eggs in the desert, left them to be hatched by the sun, and cherished no 
affection for her young. This, indeed, is the character she bore in the ancient days of the prophet Jeremiah, who compares the Ostrich to the unnatural mothers of Zion: Even the sea monsters draw out the breast, they give suck to their young ones; the daughter of my people is become cruel, like the Ostriches in the wilderness.-Lam. iv. 3. It is certainly true that she does lay her eggs in the desert, leaving them by day to the warmth of a burning sun; but no sooner does the evening set in, than swiftly she hastens across the wild tracts of sand, over which she has, throughout the day, been wandering, in search of a scanty supply of food, and all night long she covers them with the tenderest care.

The American Ostriches (Struthio Rhea,) are not only most affectionate, but sociable, laying together in the same nest, or rather the same hole, showing equal attention to their joint broods; and that they are not deficient in attachment towards each other, the following affecting story fully proves.

A pair of Ostriches had long been kept in the Zoological Gardens at Paris. The skylight over their heads having been broken, the glaziers proceeded to repair it, and in the course of their work let fall a triangular piece of glass. Not long after this the female Ostrich was taken ill, and died, in an hour or two, in great agony. The body was opened, and the throat and stomach were found to have been dreadfully lacerated by the sharp corners of the glass, which she had swallowed. From the moment his companion was taken from him, the mate had no rest; he appeared to be incessantly searching for something, and gradually wasted away. 
IIe was moved from the spot, in the hope that he would forget his grief: he was even allowed more liberty; but nought availed, and he literally pined away till he died.

Their swiftness is proverbial; to run like an Ostrich is, in its own country, the same as to say in ours, to run like a greyhound. When roused from the desert, with their long legs and huge strides, they scour away beyond a horseman's speed, with their short wings expanded to balance them. Vain would be the hope to catch them at first setting off, for, in a few minutes, they are out of sight. The persevering hunter, however, keeps on a steady course, sparing his horse, till he can again see his game at a distance, when off it runs once more, and thus, at length, by over exertion, wears itself out, its joints becoming stiffer after every run, till finally the horseman approaches near enough to shoot it.

In Morocco the Arabs adopt another method. Mounted on swift desert horses, called heiries, they set off in parties of about twenty, riding against the wind, till they meet with the track of an Ostrich, separating themselves at distances of about half a mile apart; when, as soon as they obtain a view of their game, they spur onwards at full speed. For a time, the bird runs from the magainst the wind, till finding its wings an impediment, it turns round and foolishly runs towards them, when every huntsman fires, as opportunity occurs, until they bring it down.

At Bornou, in the interior of Africa, they adopt a very different method, for which, patience instead of speed is required: on finding a nest, a hole is dug, in which the finder buries himself, leaving only his 
head and arms free, and then quietly waits the return of the bird; and when she is steadily seated on her nest, an arrow is shot through her head.

So great is their muscular strength, that tame ones will run along with a person on their back;

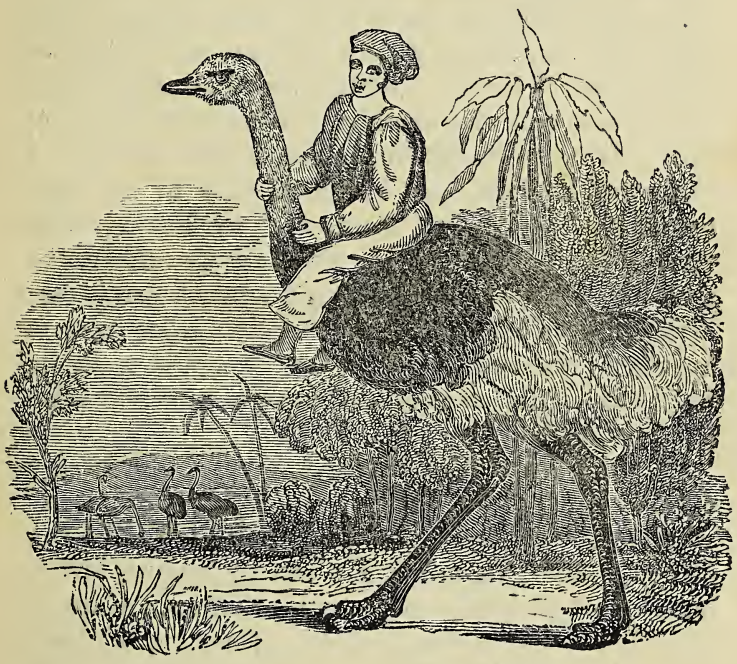

and it is on record, that F. Firmius, who reigned in Egypt in the third century, was drawn in a chariot by Ostriches. Their strength of leg renders them sometimes very mischievous; and at a farm in the Cape of Good Hope, the owner was obliged to kill a favourite tame one, which was not satisfied with swallowing chickens whole, and trampling hens to 
death, in order to tear them in pieces, but at last took to trampling even sheep to death.

The Cassowary and Emu in many respects resemble the Ostrich, differing from him chiefly in the plumage, which, in the former, partakes more of the nature of hair or bristles, than of feathers. They are lively birds, and frisk and dance away when roused, when they look very like a woolly cushion, on the top of two poles. Like the Ostrich, they are stupid, and like it, also run with amazing swiftness; so much so, that it is very difficult to run them down, unless by the swiftest dogs, and by them only in an open country. They defend themselves by kicking with their powerful legs, and the blow is quite sufficient to stun a dog, or even at times to fracture a man's leg; accordingly, dogs trained for hunting them, always approach the running bird, not immediately in its rear, but a little on one side, so as to turn and seize it by the body.

In the Emu of New Holland, there is also a very curious internal bag, or pouch, connected with the windpipe, but having no communication with the other air-cells; its use is not exactly known, but it has been ingeniously conjectured, that in a country like New Holland, parts of which are particularly exposed to sudden floods, the sandy plains in the interior are inundated, and the Emus, in seeking their food amongst, or attempting to escape from these marshes, must be often obliged to have recourse to swimming; which, considering their weight, would be difficult, were it not for the power of filling this pouch with air, and thus keeping their heads and necks above water. That this is correct, we have 



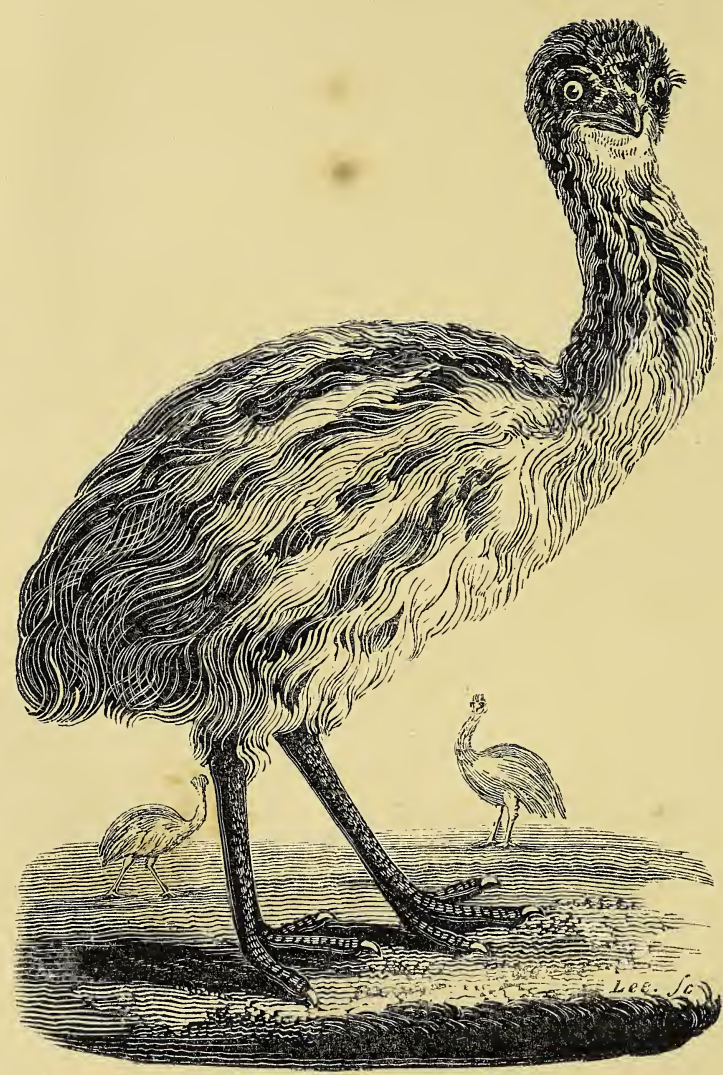

The Emu, or Cassowary. 
good reason for believing: for Captain Short, in the account of his recent expedition into the interior of Australia, mentions the fact of two Emus swimming across the Morumbidgee, in a part of considerable width and rapidity, which they would never have ventured to attempt, so peculiarly are they in body and limb unfitted for swimming, without some internal capacity, similar to the above*.

Of the last bird in this list, the Dodo, no particulars are known; for although there is no doubt of its having been in former times abundant in some of the islands of the Indian Ocean, it has long ceased to exist, and must now be considered as extinct a species as those extraordinary animals whose bones are occasionally found in a fossil state in rocks and caves.

* See note on the pouch of the Hurgila, p. 141. 
CHAPTER V..

WATER BIRDS. - WADERS. - PRESSIROSTRAL-NARROW BEAKED. - WATER-HENS-ANECDOTES OF-NESTS OF. -COOTS-NESTS OF.-JACANAS-SINGULAR FOOT OF. -HORNED SCREAMERS.-RAILS.-OYSTER CATCHERS - TAMED. - CULTRIROSTRA-CUTTING BILLED. HERONS - TOOTHED-CLAW OF - VORACITY OF.STORKS AND CRANES-MIGRATIONS OF-RESPECT PAID TO.-GIGANTIC CRANE-PARTICULARS RESPECTING. JABIRU. - ANASTOMUS-OPEN-BEAKED.-TANTALUS.

Table XXII. (See vol.i., p. 20.)

Order 5. Waders. Tribe 1. Pressirostres, (Narrowbeaked.)

WE now come to a different class of birds from those of which we have been hitherto treating, though still with a connecting link between them, so fine as scarcely to mark the point where the one begins, or the other ends: a numerous and -widely-extended race, living and seeking their food more or less amongst the waters. Some are fitted for swimming, - others are not: to make up for this deficiency, the latter are furnished with long legs for wading, or long bills for penetrating the mud,usually, though not always, with both.

The first of these to which we would allude, is the Water-Hen (Gallinula chloropus). That pretty, smart, active bird, which we may almost at any time see, if we peep cautiously and silently through the bushes of an old marsh-pit, in a meadow, or a pond half choked up with rushes, or well-paved, if we may so express ourselves, with the broad floating leaves of 
the water-lily, or persicaria (Polygonum amphibium). In the middle of any such little open space she may be usually detected, swimming about with a joyous sort of jerking motion, but on the least rustle to excite a suspicion that an enemy is near, gliding silently through the narrow channels, or running with a light tread over the floating leaves, to seek invisible shelter under the roots or hollows of the bank. Not that she always prefers the water,-for often in the evening, she may be seen wandering in the new-shorn grass of a hay-field, easily distinguishable by the white feathers on her wing and vent, and a peculiar jerk or flirting of the tail. But with all her shyness, she is, nevertheless, a tame and sociable bird; and, if treated with kindness, will show a marked confidence. We have seen Water-Hens visiting the lawn of an inclosed garden, and remaining there, notwithstanding the constant intrusion and barking of parlour-dogs, Peacocks, and tame Pheasants; and again, not unfrequent intruders in a barn-yard, mixing in a party of poultry. But, at the residence of a clergyman, near Cheadle, in Staffordshire, a much more striking instance of familiarity has for some years occurred. Adjacent to the lawn there is a moat, on which a pair of Water-Hens were observed for several seasons, always, however, leaving it in the Spring. By being constantly fed, they in time became quite tame, and at length, were induced to breed there, from the circumstance of a thorn-bush, covered with ivy, having fallen into the water, in which they afterwards continued to build their nest. When the young are a few days old, the old ones bring them up close 
to the drawing-room window, where they are regularly fed with wheat; and, as the lady of the house pays them the greatest attention, they have learned to look up to her as their natural protectress and friend; so much so, that one bird in particular, which was much persecuted by the rest, would, when attacked, fly to her for refuge; and, whenever she calls, the whole flock, as tame as barn-door fowls, quit the water, and assemble around her, to the number of seventeen (November, 1833). They have also made other friends, in the dogs belonging to the family,-approaching them without fear, though hurrying off in great alarm, on the appearance of any strange dog. The position of the water, together with the familiarity of these birds, have afforded many interesting particulars respecting their habits. They have three broods in a season-the first early in April; and they begin to lay again when the first hatch is about a fortnight old. They lay eight or nine eggs, and sit about three weeks, - the cock alternately with the hen. The nest in the thorn-bush is placed, usually, so high above the surface of the water, that when the young are first hatched, and have quitted it, they cannot climb into it again; but as a substitute, within an hour after they leave the nest, the cock bird builds a larger and more roomy nest for them, with sedges, at the water's edge, which they can enter or retire from at pleasure. For about a month, they are fed by the old birds, but soon become very active in taking flies and water-insects. Immediately on the second hatch coming out, the young ones of the first hatch assist the old ones in feeding and hovering 
over them, leading them out in detached parties, and making additional nests for them, similar to their own, on the brink of the moat.

On the appearance of the third brood, the old ones invariably drive the first away to a neighbouring pond, where they remain till September, when the last hatch is about half-grown. About this time, a fresh party of birds makes its appearance, which, from their tameness, is no doubt composed of broods formerly bred there; and in the moat, the united families remain till the following Spring, when the original pair drive all the rest away, but not without many severe and curious contests, frequently in the water, when they throw themselves on their rumps, and strike at each other with their feet. When either of the combatants begins to find himself worsted, he dives, and does not reappear,thus eluding his adversary, by hiding his whole body under water, and merely exposing his beak for respiration.

During the breeding season, they are constantly adding materials to their nest, making sad havoc in the flower-garden; for, though straw and leaves are their chief ingredients, they seem to have an eye for beauty, and the old hen has been seen surrounded with a brilliant wreath of scarlet anemones. As in this case, so do they usually build their nests on stumps of trees, or convenient bushes, by the side of the water; and, artlessly formed as it is of a few rushes, one might suppose that it would be easily discovered; which would be the case, but for the caution adopted by the bird, who, before she quits her eggs, covers them carefully up, for the joint purpose of 
concealment and warmth. A person, fishing on the banks of the Thames, when passing a willow-bed, heard a slight rustling motion: suspecting it to proceed from some water-bird, he kneeled down, and remained perfectly quiet, when the noise ceased. On rising, and looking about, he saw a Water-Hen busily employed in collecting dry rushes and flags, and laying them one by one over her eggs, deposited in one of these bare nests close beside her. It was not long before she had completely hidden them; and then, looking round with a cautious glance, not aware that her motions were observed, softly and silently glided away amongst the reeds, and disappeared. On a nearer approach, strange to say, the nest was with difficulty found, and no one, who had not previously ascertained its existence was thereabouts, could possibly have discovered it.

We have said that they usually build either upon a level with, or very little raised above the water, but not invariably so,--for, although almost entirely confined to the water, as their abiding as well as feeding-place, they will not only perch on trees. when roosting, but even build their nests at a considerable elevation above the ground. An instance of this occurred in Surrey, where the attention of a person, who had landed upon an island in the middle of a large pond, was drawn to a mass of dry rushes, flags, and reeds, strangely heaped together, about twenty feet above the ground, in a spruce-fir tree. Curiosity induced him to climb up,-when, to his surprise, out crept a Water-Hen, which dropped into the pond, and made off towards the shore.

But it is not only in their instinctive attachments 
and habits, that they merit notice: the following anecdote, proves that they are gifted with a sense of observation approaching to something very like reasoning faculties. At a gentleman's house, in Staffordshire, the Pheasants are fed out of one of those boxes described in page 98 , the lid of which rises with the pressure of the Pheasant standing on the rail in front of the box. A Water-Hen, observing this, went and stood upon the rail as soon as the Pheasant had quitted it; but the weight of the bird being insufficient to raise the lid of the box, so as to enable it to get at the corn, the Water-Hen kept jumping on the rail, to give additional impetus to its weight; this partially succeeded, but not to the satisfaction of the sagacious bird. Accordingly, it went off, and soon returning with another bird of its own species, the united weight of the two had the desired effect, and the successful pair enjoyed the benefit of their ingenuity. We can vouch for the truth of this singular instance of penetration, on the authority of the owner of the place where it occurred, and who witnessed the fact.

Nearly allied to the Water-Hen, is the wellknown family of Coots; - they, too, build a simple rushy nest, but with this difference,--that instead of seeking to raise it above the water, they seem to prefer its floating upon the very surface; where, of course, it is exposed to the double danger of being carried hither and thither, according as the wind blows; or, if interwoven with reeds or bushes close to the water, of being covered, should the waters be raised by floods. But the Coot is apparently well aware of these possibilities, and accordingly 
guards against them; preventing the nests being carried away, by ingeniously fastening the materials of which they are made to the rushes or osiers near them; but at the same time, these fastenings are of such a nature as to allow of the nests rising with the water, so that no ordinary flood would expose them to the danger of immersion. The Coot, like the Water-Hen, covers her nest, and, if not so effectually, yet with a most extraordinary rapidity. We have repeatedly watched a Coot quietly sitting on her nest: if the boat approaches, she rises, and immediately begins pecking away, right and left, which she continues to do till the enemy is so near, that she is compelled to decamp for her own preservation. In this short time, however, she almost always contrives to cover the eggs; and though the nest itself remains a very conspicuous object, a careless observer might pass it as deserted and empty.

When the young are hatched, they look more like little puff-balls than the bodies of birds, with their bright red heads sticking out like handles. For some days, they lead a weary life, exposed as they are to the attacks of pike, and we believe of rats, which devour numbers of them, in spite of the flouncings and flappings of the poor mother, who in vain tries to drive away the intruder., It is surprising, indeed, how any of them escape; for though they are tolerably active, no efforts of theirs are sufficient to elude the swift, unerring, openmouthed dart of a voracious pike. Against other enemies, they can make a better defence; and we have frequently witnessed the beautiful instinct 
with which they manage to elude pursuit. On seeing a fleet of these little red-headed floaters, paddling away in the rear of their two velvet-coated parents, we have often given chase. It is not till the danger of capture becomes imminent, that the old ones desert their charge, first giving the convoy a signal to disperse, by a few short but most expressive clucks. When hard pressed, the young bird dives, and, if the water is clear, may be traced, working away with all its energies; but, after remaining about a minute below, during which time it will dive some fifteen or twenty yards, it is forced to rise, and the chase is renewed. After a few divings, it becomes exhausted, and is easily taken. The downy covering, too, seems to partake of the weakened force of the body; for the harder the little bird is pressed, the more susceptible is it of moisture; and, instead of rising above the water glossy and dry, like a powder-puff, it becomes wet and spongy. Should it, however, contrive to gain a patch of weeds before it is quite exhausted, it seems to disappear by magic; in vain is its rising looked for, not a ripple betrays its progress; and, had we not been fortunate enough, in several instances, to detect it, cowering about an inch below the surface, its body under the shelter of a floating leaf, and its beak projecting just to admit an occasional supply of air, we might have concluded that the poor little bird had either fallen in with a pike, or fairly foundered. As if conscious of their safety, we have watched them, remaining motionless for several minutes together, and then taken them up before they had time to struggle. 
Foxes are said to be fond of Coots, and when the waters they frequent are frozen up, it is not improbable that many fall victims. This may probably account for their returning in diminished numbers after long frosts. On a mere, where, from constant observation, we knew the precise number, they would remain as long as a few square yards of water are unfrozen, sitting on the ice, or swimming with a sort of despairing restlessness, round their rapidly contracting space, as if unwilling, while hope of thaw was left, to seek shelter elsewhere. Even when this, their last opening, is sealed up, they will, for a day or two, linger amongst the rushes on the borders; but at length, they disappear altogether; and in vain have we sought them in the ditches and open streams adjacent. Where they go, we never could tell, but it is probable, to some distance, as they seldom return till many days after the frost has broken up, and Ducks, and other water-birds, common to the mere, have reappeared.

The third genus in this table comprises the Jacanas, a tribe of Waders, or rather we should say,

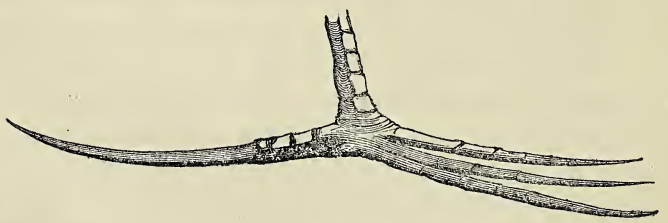

THE FOOT OF THE AFRICAN JACANA.

walkers on the water; for, by means of their very long toes, they are enabled to walk with ease orer 
the large water-plants, whose leaves form a floor, as it were, over the surface. They are inhabitants of the marshes of warm climates, and so shy, that those who hunt for them can only approach by covering themselves with leaves.

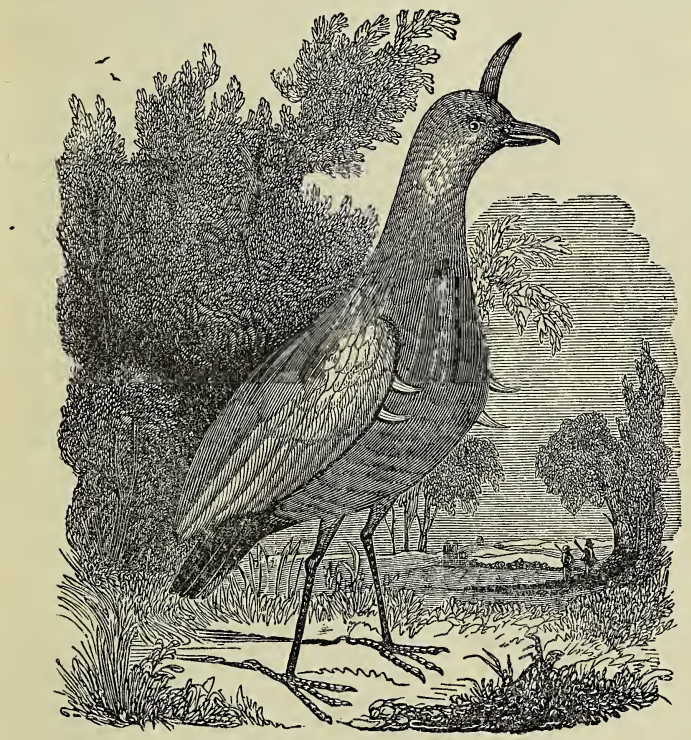

THE HORNED SCREAMER.

The means of defence in some of the Jacana species are very singular. Thus, the Horned Screamer (Palamadea cornuta), of which we annex a plate, so called from its peculiar shrill and piercing cry, and the long 
horn upon its head, is abundantly supplied with spurs; having, in addition to this upon its head, two very sharp ones upon each wing, and, by means of these spines, they fight dreadfully during the breeding season, - the conqueror remaining with a selected female, to whom he remains constant. So attached indeed are they to each other, that if one dies, the survivor usually pines away and dies too.

But, with all this warlike appearance, its character is rather mild: one species is often tamed, and from its being a resolute enemy to certain birds of prey, which make sad havoc in the poultry-yards, the inhabitants of the countries where it is found, rear it as a protector for their fowls, as it not only feeds with them, but accompanies them into the fields, and brings them back in the evening. It has in consequence been named the faithful Jacana (Parra chavaria).

The fourth genus consists of the Rails, including our Corncrake and Water-rail, which may be called English Jacanas,--as, in manners and habits, there is a considerable resemblance: they differ from the Coots chiefly in having no plate or horny-shield covering the forehead, and from the Jacanas, in not having their wings armed with spines. They are rarely seen, as they feed, morning and evening, amongst reeds and marsh-growing plants, and conceal themselves during the day in long grass, or ditches, from whence it is difficult to rouse them, as they run very swiftly, and will not rise if they can avoid it.

The fifth and last genus consists of OysterCatchers, or Sea-Pies, from the black and white 


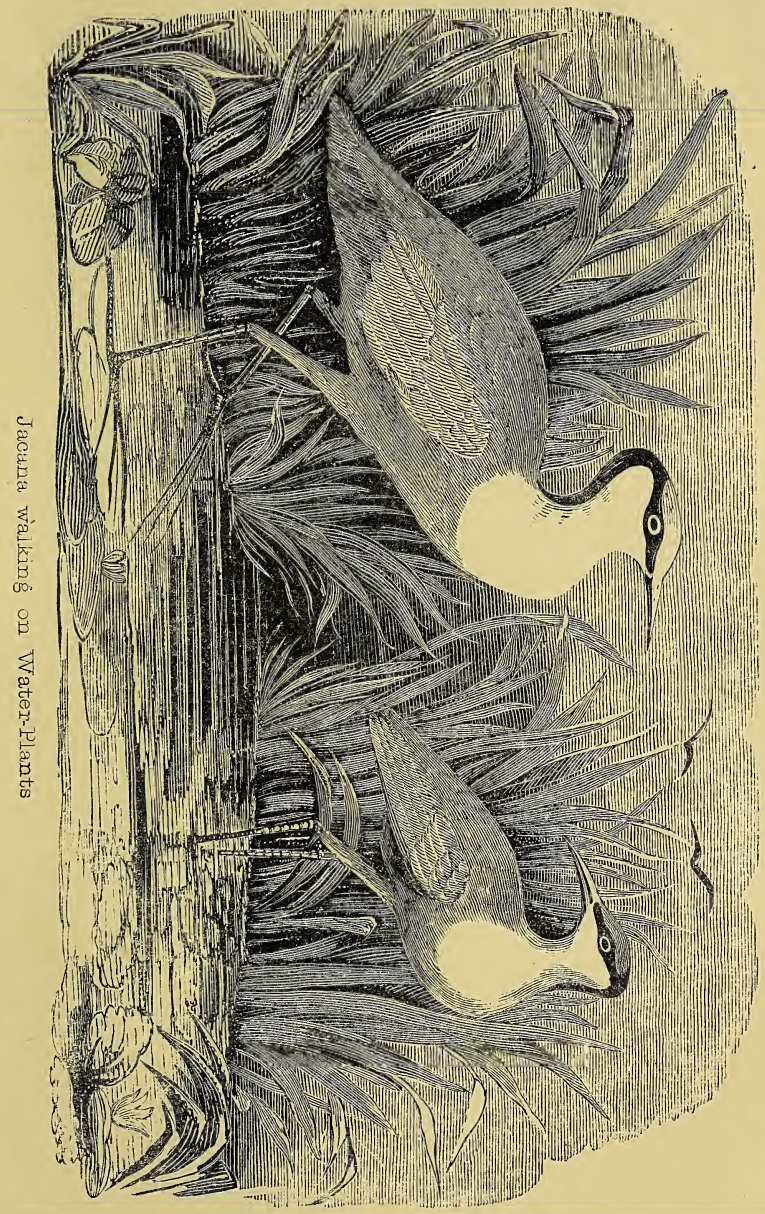



plumage of our British species bearing some resemblance to that of the Magpie. They live by the sea-side, feeding on marine insects, for which they may be seen actively searching at low water. Their name of Oyster-Catcher is also derived from their expertness in extracting the oyster, which however can be done only when the shell is open, and not even then without great caution; for instances have been known of the unfortunate bird being made prisoner by the oyster closing upon its beak.

Its eggs are laid on the bare ground, for the nest, if it deserves to be so called, consists only of small shingle and shells thrown up by the sea, so little above high-water mark, that in high spring-tides they are frequently swept away. When taken young, they may be easily tamed, and we have been surprised that they are not more frequently introduced into our pleasure-grounds. We remember seeing very considerable numbers of them, some years ago, on the lawn of the Pavilion at Brighton, collected by order of his late Majesty George the Fourth, where they were running about with the tameness and familiarity of poultry. Nothing could be more ornamental than their smart pieballed glossy coats, in contrast with their long, bright, orange beaks and legs, and crimson irides. 
Table XXIII. (See vol. i., p. 21.)

Order 5. Waders. Tribe 2. Cultrinostres, (Cutting Beaks,) so called from the Latin words, culter, a knife, and rostrum, a beak.

This tribe contains the Herons, Cranes, \&c., known by their thick, long, and strong cutting bills. The first genus consists of the Herons, properly so called, which differs from the others chiefly in the middle toe being toothed or pectinated, and in having their

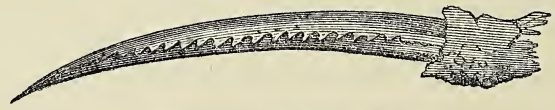

SERRATED CLAW OF THE HERON.

beaks cleft under the eyes. In other respects, they in so many points resemble the second and third genus, namely, Storks and Cranes, that they may be all looked upon as forming one family. With the Heron, however, we are most familiar, as he alone stays with us all the year round; and he may be often seen standing like a grey statue, motionless on one leg, up to his knees in water, in some retired spot, watching for fish, the very picture of patience. Impatient would he nevertheless be, if long unsuccessful, for he has a most prodigious appetite, destroying an inconceivable number of fish, which are digested almost as soon as swallowed. The powers of its stomach are indeed very great, surpassing those of most other birds; Owls, Crows, and Kingfishers, we know are unable to digest the harder portions of their food, such as bones, \&c., 


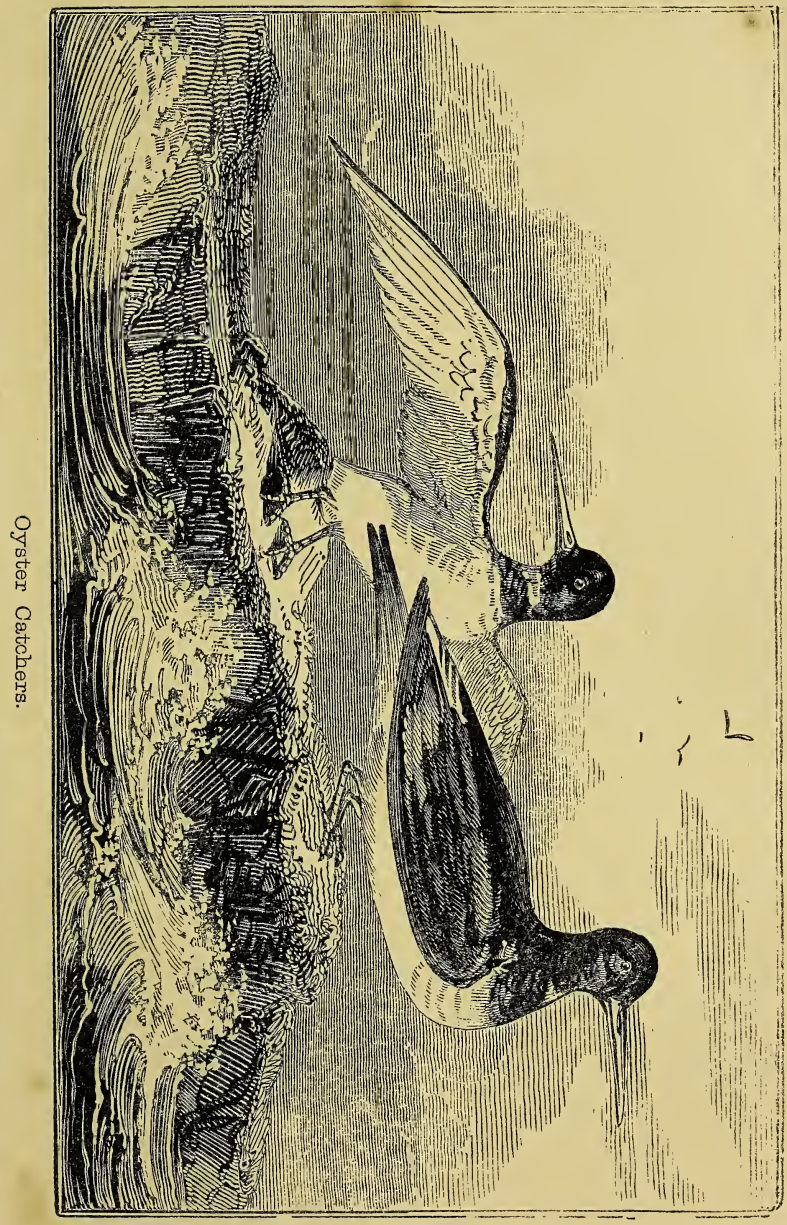



which are thrown up in pellets ; but in the Heron's stomach, they are readily dissolved. So rapid indeed is their digestion, that ignorant people have exaggerated facts, and given marvellous accounts of the feeding habits of this bird. For instance, the people of the Ferroe Islands, have a notion of the internal economy of the Heron's stomach which truth will not quite warrant, though the principle on which it is founded is correct. They imagine that it has only one large gut, white as silver, which proceeds through its whole body, and that as soon as it catches and swallows a fish, "it is under the necessity of placing its rump against a hillock or stone, to prevent the fish from getting out again; and that it stands in that position until it has been digested *." They have also such respect for its fishing powers, that they believe a Heron's foot, carried in the pocket, will ensure success.

But this opinion is not confined to the ignorant people of the Ferroe Islands: the idea was once, and very possibly, still may be, current in some parts of England, that the feet and legs of a Heron had something in them very attractive to fish, and particularly to eels, which enabled the bird, when standing in water, to bring his prey about him, and thus take it with greater facility. Accordingly, Herons were in great request with fishermen, on account of their feet and legs, which were supposed to contain an oil, which if rubbed over a worm, rendered it a sure bait for eels. Possibly, however, and indeed probably, Herons may really be gifted with some peculiar power of attracting fish.

- Landt's Travels, p. 244. 
There is a very extraordinary light, said to be visible on the breast of a species of the American Bittern; and most, if not all the birds of the Heron genus, especially our common Heron, have on their breasts a considerable space void of feathers, filled up by tufts of down, to which adheres a sort of clammy oily substance. It is not therefore unlikely that this oily matter may, either by smoothing the water or in some other way, enable the bird to attract, or, when attracted, to strike its prey with greater certainty. This idea is strengthened by a generally prevailing opinion respecting the Fish-Hawk of North America, which, when hovering over the water, is supposed to have some attractive power over its prey, upon which, when collected within reach, it pounces. The charm is believed to be an oil contained in a small bag in the body, as baits touched with a drop of it are considered to be an irresistible lure for all sorts of fish.

The Heron's feathers are also occasionally found loaded with a blue powder, which may possibly. serve its purpose in some way not hitherto discovered. Their appetite is in proportion to their powers of digestion. A heron was once seen to dart upon a large eel, and after killing it by repeatedly dashing it against the ground, gulp it all down. We have known another to consume no less than five moderate-sized eels at a single meal, which the glutton seemed quite ready to repeat within a very short time after.

Storks and Cranes are not, like the Heron, stationary, but even in the countries to which they are most attached, are regular birds of passage ; but so 
punctual in their comings and goings, that from the most remote times, they have been considered as gifted with reasoning powers. The prophet Jeremiah, speaking of their knowledge, contrasts their instinctive obedience to their Creator's laws, with the culpable departure therefrom by those on whom God had bestowed the higher gifts of reason and understanding. "Yea, the Stork in the heaven knoweth her appointed times; and the Turtle, and the Crane, and the Swallow, observe the time of their coming; but my people know not the judgment of the Lord."-Jeremiah viii. 7.

So punctual is the arrival and departure of the various migratory birds, that, to this day, the Persians, as well as ancient Arabs, often form their almanacks on their movements. Thus, the beginning of the singing of Nightingales was the commencement of a festival, welcoming the return of warm weather; while the coming of the Storks was the period of another, announcing their joy at the departure of Winter. The expression, "the Stork in the heaven," is more applicable than at first appears, for even when out of sight, its pathway may be traced by the loud and piercing cries, peculiar to those of the New as well as of the Old World*. In Americat, too, its migrations are equally regular, passing its immense periodical journeys at such a prodigious height as to be seldom observed. It is satisfactory thus to strengthen the authority of a Scriptural passage from so distant a source, though amply borne out by witnesses in the very country in which the prophet dwelt.

* See p. 77, vol.i. + Heron's Journey in North America. 
"In the middle of A pril," says a traveller* in the Holy Land, "while our ship was riding at anchor under Mount Carmel, we saw three flights of these birds, each of which took up more than three hours in passing us, extending itself, at the same time, more than half a mile in breadth." They were then leaving Egypt, and steering for Palestine, towards the northeast, where it seems, from the account of another eye-witness, they abound in the month of May. "Returning from Cana to Nazareth," he observes, "I saw the fields so filled with flocks of Storks, that they appeared quite white with them; and when they rose and hovered in the air, they seemed like clouds. The respect paid in former times to these birds is still shown ; for the Turks, notwithstanding their recklessness in shedding human blood, have a more than ordinary regard for Storks, looking upon them with an almost reverential affection."

In the neighbourhood of Smyrna, and indeed throughout the whole of the Ottoman dominions, wherever the bird abides during his Summer visits, it is welcomed. They call him their friend and their brother, the friend and brother exclusively of the Moslem race, entertaining a belief that wherever the influence of their religion prevailed, he would still bear them company; and it might seem that these sagacious birds are well aware of this predilection: for singularly enough, a recent travellert, who met with them in incredible numbers in Asia Minor, observed, that although they built on the mosques, minarets, and Turkish houses, their nests

* Chardin.

+ Macfarlane's Constantinople. 
were never erected on a Christian roof. In the Turkish quarters they were met in all directions, strutting about most familiarly, mixing with the people in the streets, but rarely entering the parts of the town inhabited by the Greeks or Armenians, by whom, possibly, they may be occasionally disturbed. Nothing can be more interesting than the view of an assemblage of their nests. Divided as they always are into pairs, sometimes only the long elastic neck of one of them is to be seen peering from its cradle of nestlings, the mate standing by on one of his long slim legs, and watching with every sign of the closest affection. While other couples, on the adjacent walls, are fondly entwining their pliant necks, and mixing their long bills, the one sometimes bending her neck over her back, and burying her bill in the soft plumage, while her companion clacking his long beak with a peculiar sharp and monotonous sound, raises her head and embraces it with a quivering delight; while from the holes and crannies of the walls, below the Storks' nests, thousands of little blue Turtle-Doves flit in all directions, keeping up an incessant cooing by day and night.

At another Mohammedan town, $\mathrm{Fez}$, on the coast of Barbary, there is a rich hospital, expressly built, and supported by large funds, for the sole purpose of assisting and nursing sick Cranes and Storks, and of burying them when dead! This respect arises from a strange belief, handed down from time immemorial, that the Storks are human beings in that form, men from some distant islands, who, at certain seasons of the year, assume the shape of these birds, that they may visit Barbary, and return at a fixed 
time to their own country, where they resume the human form. It has been conjectured, that this tradition came originally from Egypt, where the Storks are held in equal respect, as we shall see, when we speak of their sacred bird, the Ibis. By the Jews the former was also respected, though for a different reason; they called it Chaseda,which, in Hebrew, signifies piety, or mercy,-from the tenderness shown by the young to the older birds, who, when the latter were feeble or sick, would bring them food.

This affection, however, appears to be mutual, for the parent birds have a more than common degree of affection for their young, and have been known to perish rather than desert them. An attachment of this sort once occasioned the death of an old Stork, at the burning of the city of Delft, in Holland. When the flames approached her nest, situated on a house-top, she exerted herself to the utmost to save her young; but finding every effort useless, she remained and perished with them. Besides the Jews, other ancient nations held these birds in veneration. A law among the Greeks, obliging children to support their parents, even received its name from a reference to these birds*. By the Romans it was called the pious bird, and was also an emblem on the medals of such Roman princes as merited the title of Pius. Of their attachment towards each other, we can give another instance, which occurred in this country.

A gentleman had for some years been possessed 
of two brown Cranes (Ardea pavonia), one of them at length died, and the survivor became disconsolate. He was apparently following his companion, when his master introduced a large looking-glass into the aviary. The bird no sooner beheld his reflected image, than he fancied she for whom he mourned had returned to him; he placed himself close to the mirror, plumed his feathers, and showed every sign of happiness. The scheme answered completely: the Crane recovered his health and spirits, passed almost all his time before the looking-glass, and lived many years after, dying at length of an accidental injury.

In return for this attachment, the male expects the strictest fidelity from his partner; and it would seem, from the following anecdote, that severe punishment awaits the mother suspected of inconstancy. We do not recollect where the first occurred, but the latter, which was seen by numbers of the most respectable persons, and communicated from the best authority, lately took place near Smyrna. Some hens' eggs were placed in a Stork's nest, and the others removed. The female Stork, not aware of the change, sat patiently the appointed number of days, till the shells were broken, and the young chickens made their appearance. No sooner were they seen by the old birds, than they testified their surprise by harsh notes and fierce looks, and after a short pause, they jointly fell on the unfortunate chickens and pecked them to pieces, as if conscious of the disgrace which might be supposed to attach to a dishonoured nest. Whether the female suffered afterwards, we do not know. We shall see, 
however, by the following, that the expected consequences of such a discovery might well account for the horror and indignation manifested by the wondering parents.

A French surgeon, at Smyrna, wishing to procure a Stork, and finding great difficulty on account of the extreme veneration in which they are held by the Turks, stole all the eggs out of a nest, and replaced them with those of a hen: in process of time the young chickens came forth, much to the atonishment of Mr. and Mrs. Stork. In a short time Mr. S. went off, and was not seen for two or three days, when he returned with an immense crowd of his companions, who all assembled in the place, and formed a circle, taking no notice of the numerous spectators, which so unusual an occurrence had collected. Mrs. Stork was brought forward into the midst of the circle, and after some consultation, the whole flock fell upon her, and tore her to pieces; after which they immediately dispersed, and the nest was entirely abandoned.

We suspect that constancy and fidelity amongst birds exists to a greater degree than we are aware of ;-whatever testimony can be collected on the subject, certainly tends to prove it. Thus, a pair of Magpies had built their nest in a tree, where they were constantly under the observation of a person whose house was near at hand. One morning early, during the absence of the male, the female flew from her tree to a field hard by, where she was soon joined by a male, who paid her great attention. During this interview the mate returned to the nest, and on seeing his partner hopping about familiarly 
with another, he immediately darted upon the guilty parties, and attacking them with the greatest anger and fierceness, put them to flight, and followed them: whether he killed his faithless partner or not was unknown, but she never returned; and the deserted widower, after occasionally visiting his nest for a day or two, finally quitted it, and disappeared altogether. It is not improbable, indeed, that similar suspicions or prejudices may have been the cause of some of the mysterious meetings already mentioned, in which individuals were put to death.

Of this tribe, there is one which, from its extraordinary size, shape, and appearance, deserves to be particularly noticed. It is called the Gigantic Crane (Ardea argila), a native of the East Indies, and was the first of birds to meet the eye of Bishop Heber, on his landing in India. "In the morning, as the day broke," says he, "we were much struck by the singular spectacle before us. Besides the usual apparatus of a place of arms, the walks, roors, and ramparts of the fort, swarmed with gigantic birds, the Hurgila, larger than the largest Turkey, and twice as tall as the Heron, which, in some respects, they much resemble, except that they have a large blue and red pouch under the lower bill, in which, we were told, they keep such food as they cannot eat at the moment. These birds share with the jackalls, who enter the fort through the drains, the post of scavenger; but unlike them, instead of shunning mankind day and night, they lounge about with perfect fearlessness all day long, and almost jostled us from our paths." The bishop's information, however, respecting this pouch, is not correct; 
it having been ascertained that this bag is not at all connected with the gullet, and has, therefore, no reference to food, but is merely an air-vessel on a very large scale, employed as occasion requires, either in sustaining the bird in its lofty soaring flights, or assisting it in searching for food in its original dwelling-places, amongst marshes and lakes. Its natural food in these situations consisting of reptiles and amphibia, it must often find it necessary to go beyond the depth of even its long legs, while from the structure of its limbs, it cannot swim, and it is evident that its ponderous awkward beak would prove an additional incumbrance. To overcome these difficulties, the bag, when filled with air, may be of great service, by conteracting the weight of this enormous bill, and thus enabling it to procure food in deep water. And this view of the subject seems to be confirmed by the testimony of an experienced witness, by whom a Hurgila was seen, wading in a large piece of water, and proceeding to a distance from the shore, which was afterwards found to be beyond its depth. The conclusion, therefore, was, that by filling this pouch with air, it was enabled to support itself*. That its further use may be to supply it with air in its soaring flights, there are also good grounds for supposing. When the dense vapours of the rainy months are dispersed, and the sun has again burst forth with undiminished fervour on the Indian plains, the Hurgilas are observed to avoid the sultry heat of the lower regions, by taking refuge in the higher, rising gradually

* It appears to be analogous to the pouch of the Emu, and applicable in part to similar purposes. See p.116. 


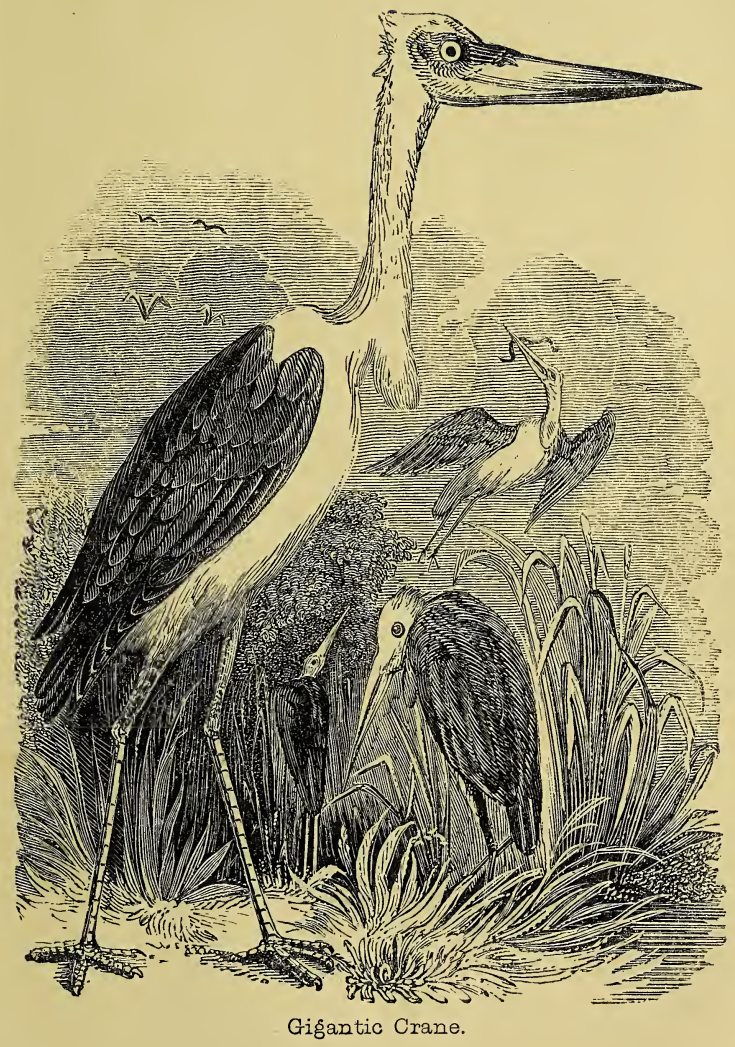



till they appear mere specks in the firmament, or entirely lost to the sight. In the hot months, when not a cloud obscures the vault of the heavens, hundreds of these gigantic birds may be seen performing their graceful evolutions, and wheeling majestically at a vast height,-enabled to remain in so thin an atmosphere, most probably, by the supply of air collected in this bag.

In its appetite the Hurgila is as great a glutton as our Heron. Nothing comes amiss to its all-digesting stomach. A leg of mutton, and a litter of live kittens swallowed whole, proved equally acceptable, with the additional sauce of earth, bones and hair, picked up between times.

The fourth genus, Jabiru, very much resembles the Storks, and appears to have similar habits, the chief distinction consisting in the form of the bill, which is rather fuller, and slightly curved upwards at the end. The skin of the neck is wrinkled, and

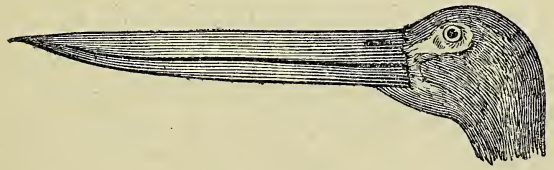

BEAK OF THE JABIRU.

so flaccid, that it hangs down like the dewlap of a cow, and probably may be of the same use as the pouch of the Hurgila above mentioned. It is, indeed, from considering this dewlap as an air-vessel, that it derives it's name Jabiru, which, in the language of the Guarani Indians, in South America, signifies 
anything inflated by wind; and they, like the Hurgilas, not only frequent marshes, but rise slowly to immense heights, where they will remain for a considerable time.

We cannot take leave of the Heron family without putting our readers on their guard against a very dangerous instinctive faculty they seem to possess, of depriving their assailants of eye-sight. If wounded, they will allow a dog to approach, and then, though apparently insensible, will, in an instant, with unerring aim, dart at its eye, with a force, rapidity, and certainty, which it is almost impossible to guard against. We remember a gentleman who narrowly escaped; he had, as he conceived, killed a Bittern, and deposited it in a large pocket of his shootingjacket: when, fortunately, as he was walking on, happening to feel something insinuating itself between his arm and side, he, just in time to save his eye, caught sight of the beak of the Bittern, which had been only wounded, and was in the act of lancing itself, with the full elastic jerk of its long neck, towards his face. This faculty, however, is not entirely confined to either the Heron or Bittern, it extends itself to other species, as appears from the similar escape of a naval officer, on the coast of Africa. "I winged," says he, "a beautiful white Aigrette, that was passing over head, and brought it to the ground; when, as I was in the act of picking it up, it struck at my eye with its beak, and had it not been for my glasses, must inevitably have reduced it to perpetual darkness." "I have since," he adds, "heard of a gentleman, who, under similar circumstances, was not so fortunate; he still lives, 
and I shall feel pleasure, if, by stating this incident, it should be the means of saving others from so distressing a circumstance *."

Of the fifth genus, Anastomus, or Open-Beaks, little is known, except that their habits and food are similar to those of the preceding genera. The beak is the prominent distinguishing feature; the edges of which, instead of closing throughout, meet only at the extremities.

The sixth and last genus, is that of the Tantalus, all foreigners, inhabiting Asia, Africa, America, and Australia. They have feet, nostrils, and beaks, like those of Storks; but differ from them in the form of the bill, the back of which is rounded, and its point curved towards the bottom. They frequent marshy spots, living on reptiles and fish. When their appetite is satisfied, they retire to high trees, where they remain in an erect attitude, the bill resting on the breast. They are simple birds, and may be easily shot.

* Captain Owen's Voyages. 
CHAPTER VI.

LATIROSTRAL - FLAT-BEAKED. - BOAT-BILL. - SPOONBILL.-FLAMINGO-MODE OF FEEDING-NEST OFWATCHFUL HABITS.-TENUIROSTRAL, OR LONGIROSTRAL. - LONG, SLENDER-BILLED BIRDS. - AVOSET.SAND-PIPERS.- DOTTEREL- PRESERVATION OF ITS YOUNG.-DUNLIN'S NEST AND EGGS.-PLOVERMODE OF CATCHING.-IBIS-MUMMIES OF-WHY HELD SACRED.

\section{Table XXIV. (See vol.i., p. 21.)}

Order 5. Waders. Tribe 3. Lat inostres, (Flat-beaked.)

The three genera of this Table have been included by some naturalists amongst the cultirostral, or cutting-beaked birds, but the general form of their beaks renders them easily distinguishable under the term latirostral, or flat-beaked. The Spoon-bills, indeed, alone really deserve that title to the full extent; for the beaks of the Boat-bills and Flamingoes, though to a certain degree wide and flattened, have also a considerable degree of depth.

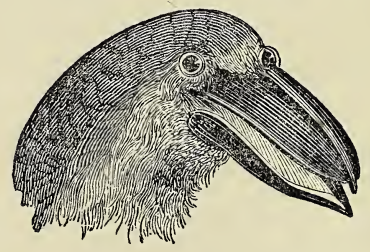

HEAD OF THE BOAT-BIIL.

The Cancroma, or Boat-bill, so called from the boat-formed shape of its beak, resembles the Heron 
in almost every other particular, and, like that bird, will dart with fury at the object of its anger; it is found in the hot and damp parts of South America, frequenting the banks of fresh water streams.

The Spoonbill cannot be mistaken, the round and flattened termination of its beak, at once pointing out the name. Sometimes, but rarely, they are found in England. Near Holyhead, in the island of Anglesey, a very fine specimen was shot and preserved in 1832. It was first seen early in May, feeding at low water, in company with some Herons, on the marine productions left by the tide, but was so shy, that some weeks had elapsed before it was killed, at three o'clock in the morning, by a man who had marked its roosting-place, on a small rocky island, accessible only on foot at low water. Another was also killed about this time, at no great distance from the same place. When rising from the ground, it always made several wide circles before getting into full flight. It was very shy, and never could be approached nearer than one hundred yards.

The Flamingo is by far the most striking of these three genera; its scientific name is Phonicopterus, from two Greek words, signifying "wings of flame," their beautiful carnation colour, contrasting with the plumes of the neck and body, which in one species are of delicate white. It is a most extraordinary bird. Its legs are of an excessive length, and so slender, that, at a little distance, standing, as they usually do, on one alone, it is not easily seen, and the bird appears as if stationary in the air. But the chief singularity is in the 
bill, which the annexed figure will explain better than any rerbal description. With this misshapen instrument, it would appear, that the act of collecting food must be an affair of some difficulty,an opinion rather confirmed by the still more extraordinary manner in which it feeds. On looking at the plate, it will be seen that, owing to the sudden curvature, or almost broken and deformed appearance of the beak, food, collected in the usual way,

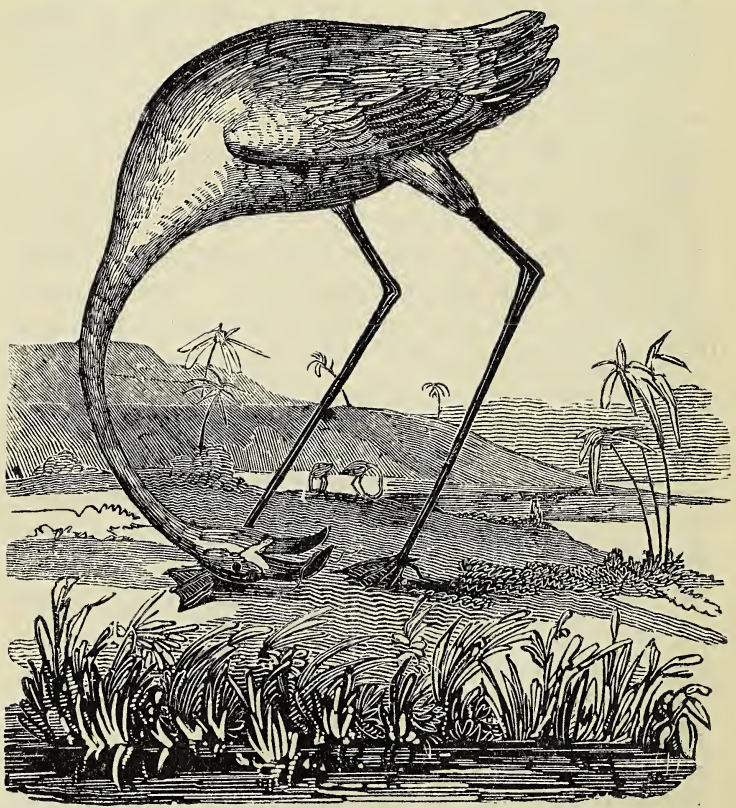

THE FLAMINGO. 
must naturally drop from the mouth; and so it would, if the bird fed as other birds do. But it adopts its own method, by turning its head, and scooping up the soft substances on which it preys, using the upper mandible as a sort of spoon.

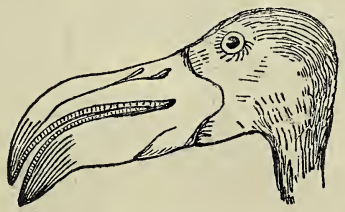

BEAK OF THE FLAMINGO.

This would certainly be inconvenient, if not impossible, to other birds; but not to the Flamingo, owing to its remarkably long, slender, and flexible neck. A still greater inconvenience would ensue, if it were under the necessity of sitting on its nest, like other birds, for it would then be utterly impossible to dispose of its long, stilted, disproportioned legs. Nature has, however, met the difficulty, and taught it how to make a nest exactly suited to its form and length of leg. It is made of mud, in the shape of a hillock, with a cavity at the top, where the eggs are laid, and the height of the hillock is such, that she can sit as comfortably on her nest as a horseman does on his saddle, leaving her legs to hang dangling down at full length on either side.

This bill, misshapen as it is, can also, in case of necessity, be used for a very different purpose from that of feeding; for one of these birds, in confinement, having been accidentally deprived of a leg, 


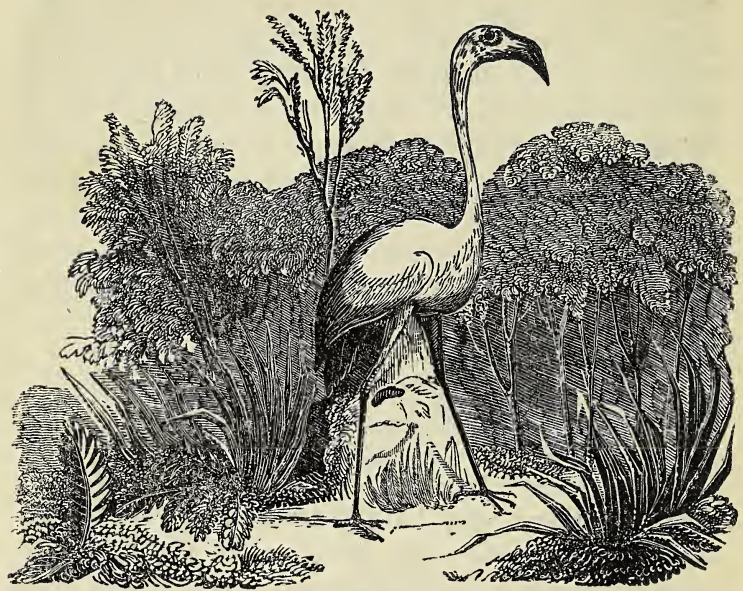

NEST OF THE FLAMINGO.

soon found a remedy, by walking with the other, and using its bill as a crutch, and probably finding it as serviceable as a wooden leg, which, strange to say, has been supplied in a similar case. The circumstance is mentioned by an eye-witness*. "A Crane, having," as he says, "had one of his legs broken, and cut off above the knee, had a wooden leg and thigh, with a joint so accurately made, that the creature could walk and use it as well as if it had been natural."

We have alluded to the bright pink and scarlet colours of the Flamingoes, which give them a

* Evelyn's Diary, vol. ii. 
soldier-like appearance, in addition to further military habits they seem very generally to adopt. Not only do they always assemble in flocks, but they form, in long lines of regular rank and file, as well for the purpose of fishing, as when they repose on the strand. Still further, after the manner of experienced soldiers, they post sentinels, who keep a good look-out, and if anything suspicious attracts their notice, immediately send forth a cry like the sound of a trumpet, when the whole corps moves off in regular marching order.

In the river Inhambau, on the eastern coast of Africa, the officers of Captain Owen's surveying ships found them so numerous that every shoal was covered with them, "looking," to use their words, "at a distance, like large variegated plains, and, upon a nearer approach, resembling files of soldiers. When the sun was shining upon them, nothing could surpass the beauty of their brilliant and dazzling appearance."

\section{TABle XXV. (See vol. i., p. 22.)}

Order 5. Waders. Tribe 4. Tenurnostres*, or Slender-billed.

By some naturalists, the birds of this Table have been classed amongst the long-billed birds (Longi-

* As there is a division of Tenuirostral birds in the Passerine Order, this tribe, to avoid confusion, is often designated as Longirostral; most of the birds composing it having long bills. We have adhered, however, to Dumeril's title. 
rostres, Cuvier); but there can be no impropriety in adhering to the arrangement here adopted, as their bills are, without exception, more or less slender and flexible, a character, indeed, more generally applicable than length, as some of them are by no means long-billed.

There are five genera :-

1. Avosets,

2. Sandpipers,

4. Curlews,

3. Phalaropes,

5. Woodcocks.

Of the first of these birds, the Avosets, there is little to be said, one species only being known in England, and this confines itself almost entirely to the fen-countries, or southern coasts: its beak is so soft and flexible, that it might be mistaken for two

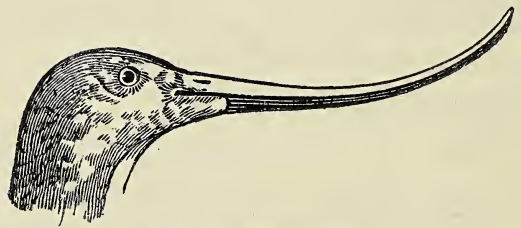

BEAK OF THE AVOSET.

thin pieces of whalebone, turned upwards considerably for about half its length. It is web-footed, but, as it never swims, the use of the web is supposed to be to support it, as it runs lightly over morasses, or soft muddy spots.

The four last genera of this Table, form nearly the most obscure and difficult division in the whole arrangement of birds,-running one into 
another, by shades so slight and variable, that it is almost impossible to trace any positive line of distinction. They comprise, under the scientific names of Tringa, Charadrius, Numenius, and Scolopax, the tribes of birds known under the more familiar appellations of Sandpipers, Purres, Plovers, Phalaropes, Curlews, Woodcocks, \&c.

Amongst the Sandpipers and Purres, we find those busy, active flocks of little birds, which so often enliven a sauntering walk along the rocks and shores of the ever ebbing and flowing sea. There they may be seen, now running incessantly with a light tripping motion, up and down, and here and there, in search of shrimps, sea-worms, or small shell-fish,and then, particularly if approached too near, taking flight at the same instant, with a whirring, whizzing sound, and a loudish whistling cry, reminding us, by their sudden changes in flight, and shades of colour, of our friends the Starlings; at one moment, appearing as a little dark cloud, if their backs are presented, and then, in an instant, almost dazzling the eye with the bright white of their under delicate plumage, occasioned by an instantaneous turn of their bodies; and, then again, seeming almost to disappear, as they dart along with their wings edgeways towards the eye. It is impossible to watch a flight of these merry, sociable little birds, without pronouncing them to be a happy race, with all the enjoyments, and few of the cares of life. The skulking, solitary gunner, who prowls about the shore, appears to be their only enemy; and, conscious of their power of keeping aloof, they seem to treat him with indifference. 
Some species of these birds, such as the RingDotterel, or Sea-Lark, have advantages over other birds, with respect to their young,-on the appearance of danger, being enabled to carry them out of harm's way. There can be no doubt of this curious fact. One of these birds was seen on a rocky shore in Anglesey, running over a sandy patch a few yards off, accompanied by two young ones. On finding herself surprised, she immediately rose with one of the young ones, either caught up, or clinging to her by its own instinctive efforts. Whether from a wish to remain as near as possible, while the other was in danger, or from the additional weight, could not be ascertained, but her flight was short, and she alighted on a rock at no great distance. The remaining little one was with difficulty overtaken, as it ran with great activity and swiftness, although very young, being covered with down, and evidently not long hatched. Most of the little birds of this tribe make no regular nests, but deposit their eggs, four in

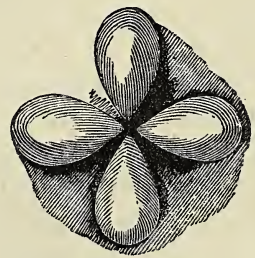

EGGS OF THE DUNLIN.

number, either on the bare sand, just beyond the high-water mark, or, like the Dunlin, or Sea-Snipe, 
on the ground among long grass and heather; exposed as the eggs then are, both to weather and observation, the bird contrives to place them so as to take up the smallest possible space; and this she effects by making them all meet at their smaller ends, which also taper more than most other eggs.

The four little eggs, for they are much smaller than a Snipe's, huddled in so narrow a compass, require a keen and accustomed eye to see them, and, at the same time, are easily covered by the parentbird. Her affection for her young is not confined to them when unable to take care of themselves after hatching, but is manifested when they are still in the egg; for should a stranger disturb her, she will, instead of running or flying away in her usual manner, immediately affect lameness, or decoy him away from the nest by tumbling over and over, as if in the last stage of weakness or decrepitude. Or, if actually found upon her nest, she will sometimes nobly persevere in sacrificing herself, rather than desert it. In two instances, amongst many, they were found to sit so close, that they allowed themselves to be lifted off their nests rather than fly away. It is remarkable how much the same instinctive habits prevail in similar families of birds. Those who may not have had opportunities of witnessing these manœuvres by the Sandpipers, have probably often watched the similar proceedings of our common Lapwing, or Pewit, which decoys a dog or a stranger away, either by screaming close to his ear, as she flits by in a sort of tumbling flight, or by scrambling along the ground as if wounded, when 
the young brood are in danger. Indeed, these latter birds, above any others, have need of all the art and cunning they can muster, to save their eggs, which are eagerly sought after in the places where they are known to breed, for the purpose of selling them at a high price, as a luxurious article of food.

In the Orkney Islands, to the north of Scotland, they were, and possibly still are, allowed to breed unmolested; and their increase is consequently very great. Probably, they were once equally unmolested in every other part of North Britain, which may account for a curious Act of Parliament, said to have been passed many years ago in Scotland, for encouragement to destroy them as " ungrateful" birds ; "for that they came to Scotland to breed, and then returned to England with their young, to feed the enemy*". Their food consists chiefly of grubs and insects, easily procured in the low mossy grounds which they prefer. Earth-worms, too, form a large portion of their diet, but as their bills are neither so long or so strong as to pierce deep enough into the soil to get at them, they adopt the following clever mode of inducing them to show themselves above ground, when they are instantly seized by the watchful Lapwing. A friend of ours, one day finding a young Plover, carried it home and kept it in a confined place. In addition to its common food, a few square pieces of turf, six or seven inches in thickness, were introduced; upon these were thrown a number of garden-worms, which buried themselves in the sods as fast as they could. Care was taken to keep them moist by frequent

* Letters from the North of Scotland, vol, i. 



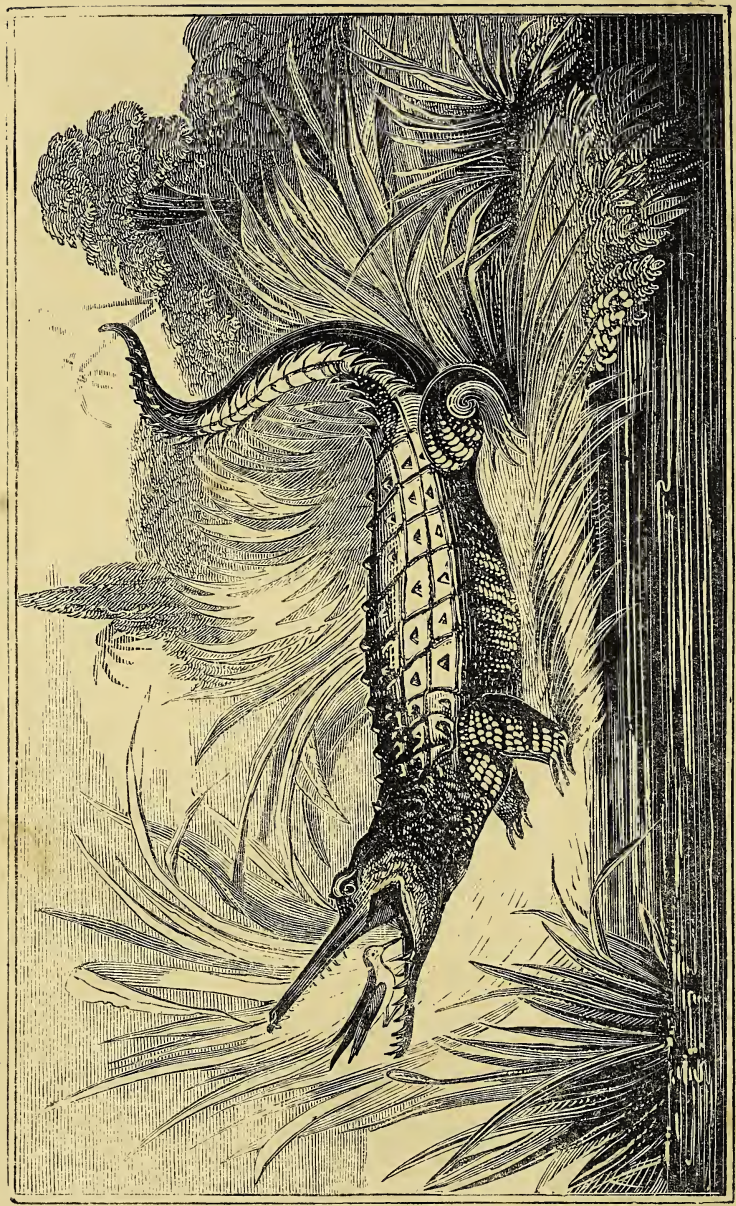


waterings. The Lapwing, when disposed to make her meal, mounted one of these sods, and, standing on one leg, kept regularly beating the turf with the other. Worms, as we have already shown, in speaking of the manner in which Starlings and Thrushes feed upon them, are very sensitive of danger,-and their great enemy being the mole, no sooner do they perceive a vibration, or shaking motion, in the earth, than they make the best of their way to the surface, and thus fall into a greater and more certain peril,for, as in the case of the Starling or Thrush, so in the present instance, no sooner did it make its appearance, than the Lapwing drew it out, and, having disposed of it, renewed his operations, till he had fully satisfied himself.

But we have another story to tell of a certain species of Plover's meals, far more extraordinary, and which we should feel great hesitation in relating had not the original observer of former days, been supported by eye-witnesses of later times. Herodotus, an old Grecian historian, asserted that there was a certain small bird, which, as often as the crocodiles came on shore from the river Nile, flew fearlessly within their jaws, and relieved them of a peculiar kind of leeches which infested their throats. This ancient historian added, that, although other birds invariably avoided the crocodile, it never did this bird any injury. So extraordinary a story was treated as fabulous by all naturalists. It is, notwithstanding, strictly true,M. Geoffry Saint Hilaire, an eminent and accurate French naturalist, confirms the fact beyond a doubt. The bird alluded to is the Egyptian Plover 
(Charadrius AEgyptiacus), which sometimes enters the mouth of the crocodile, attracted thither, not, according to his account, by leeches, but by a small insect like a gnat, which frequents the banks of the Nile in great quantities. When the crocodile comes on shore to repose, he is assailed by swarms of these gnats, which get into his mouth in such numbers, that his palate,-naturally of a bright yellow colour, appears covered with a blackish-brown crust. Then it is, that this little Plover, which lives on these insects, comes to the aid of the half-choked crocodile, and relieves him of his tormentors; and this without any risk: as the crocodile, before shutting his mouth, takes care, by a preparatory movement, to warn the bird to be off. This singular process is, moreover, not confined to the crocodiles of Egypt; it has been noticed in those of the West Indies, where, when attacked in a similar manner by small flies, called Maringouins, a little bird (Todus viridis), which lives chiefly on flies and insects, performs the same kind office.

In the above cases, the food of the bird is said to be flies, but there is good reason for believing that perfect reliance may be placed on the account of Herodotus, and that leeches and insects are the objects sought for; as a letter from a gentleman in Calcutta was read at a late meeting of the Linnæan Society, in London, describing certain leechcs which had been taken from the throat of a large alligator (which are also found to infest the throat of the Gigantic Crane, or Hurgila, already mentioned): these leeches were of various sizes, some exceedingly minute, of a florid red when alive, semi- 
transparent, and thus showing the blood they had swallowed.

In some parts of France, where Plovers fly in large flocks, they are decoyed into nets spread on the ground, by the playing of a looking-glass, which attracts their notice, - with the addition of some stuffed-birds, and here and there a live one intermixed. In another part, they are hunted at night with torches, the light of which attracts them.

Woodcocks and Snipes are too well known to require description, as far as their outward appearance is concerned. But, in their habits, and more particularly in the migrations of the former, there is much to excite our curiosity. With few exceptions, other birds manifest a fondness for each other's society, and even if they do not fly in flocks, may be found associating together, as if they disliked a lonely, solitary life. Not so the Woodcock and the Snipe; for they, except at the breeding-season, seem to shun, not only other birds, but even their own species. It may be said, that this is incorrect, because often in the same woods, or favourite marshy haunts, they may be occasionally put up in considerable numbers; but, in these cases, it should be remembered, that if many are found, the number depends, not upon any social feeling, but the attraction of their common food; a large proportion of their lives being passed alone in the solitude of a marsh, or the shaded retirement of a wood. If undisturbed, and in some cases, even although disturbed, there will the Woodcock or the Snipe remain, till called away by that instinctive faculty which impels them to visit regions far distant, and 
still more solitary; where, without fear of intrusion, they may rear their young broods. Every sportsman is well aware of the attachment evinced by these birds to some favoured spot. Upon the same patch of rushy, marshy ground, the same Jack-Snipe may be found, day after day, in spite of the annoyance to which it is often exposed from an indifferent marksman: up rises the little bird from its rushy covert, turning and winding swiftly through the air, and thus escaping charge after charge of shot, which only seems to add vigour to its wings; and after a wide whirl or two, down it darts again, often within a few yards of the seat of danger.

The difficulty of hitting this active little bird is, indeed, so proverbial, that we can readily believe a story told of a gentleman,-a very bad-shot,-who, having at length succeeded in killing a Jack-Snipe, deeply lamented the loss of a bird, which, as he was always sure of finding it in the same place, had afforded him constant amusement during a whole Winter. Of this attachment to a particular spot, and regular return to it, there can be no doubt; we have already alluded to it in the case of other birds, and Woodcocks and Snipes seem to form no exceptions to the practice. One instance amongst many, will be sufficient to prove the fact. A Woodcock was accidentally found by a keeper, entangled in a rabbit-net, and preserved alive; a brass ring was put on its left leg, and it was turned loose. This occurred in February. On finding itself at liberty, it rose to a very great height in the air, and directed its flight towards the sea, from whence it was distant about twenty miles. In 
December, this same bird was shot in the same wood, where it had been captured in the preceding February.

That Woodcocks, however, can and do breed in this country, is beyond a doubt; instances without end have occurred; one of which alone we shall notice, on account of a very.curious circumstance connected with it.

The communication first appeared in a Scotch newspaper, the Elgin Courier. In the month of April, near Dornaway Castle, the seat of the Earl of Moray, a Woodcock was flushed, which flew away as if wounded. On a person, who was present, remarking this to the game-keeper, the latter observed, that the bird was not wounded, but was carrying off a young one in her talons, and that no doubt the nest was close at hand: this was found to be the case, and two other young ones were discovered in it, which, on being disturbed, ran off, uttering a piping note. The keeper spoke very positively of its being customary with the old birds to fly off every morning and evening with the young ones, to the nearest springs, and when they were fed, they were conveyed back to the nest in a similar manner.

It may be reasonably questioned, whether the keeper's account is quite correct throughout. We should certainly doubt the latter part, but we know too little of the habits of Woodcocks, respecting their nests and management of their brood, to give a decided contradiction to the supposition of their being thus in the daily habit of moving their young ones. That a bird, in many respects allied to the 
Woodcock genus, is able to transport its young, in case of danger, we have already shown*; and future observers may possibly bear equally satisfactory testimonies to a similar power in the Woodcock.

It remains to make a few remarks on the migration of Woodcocks, which is attended with more mystery than that of most other birds. We shall endeavour briefly to state the chief points for consideration. First, we have every reason to believe that the greater proportion, on leaving this country in March, retire to the wild solitudes of Norway or Sweden. Secondly, that on re-appearing in England, in October, they are, for the most part, poor and weak. Thirdly, that instead of being first seen on the eastern coasts, they are, for the most part, known to land on the western shores of Ireland, and, almost in flocks, on the Scilly Islands, twenty miles to the westward of the Land's-End, Cornwall, quite exhausted.

Now, on the supposition that the major part are bred in Norway and Sweden, if we examine a map, it will be evident that they ought naturally to alight on the eastern shores, as the nearest points. Their weak, lean, and exhausted state, however, supposing it to arise from fatigue, implies a far longer, and more continued flight, than that from Norway, which, even supposing that they prefer, for some unknown cause, the western to the eastern shores of our island for their first appearance, is quite a trifling affair for most birds; the distance, in a straight line, from the nearest point of Norway to the Land's-End, being not more than a seven or eight hours' journey for a bird, whose rapidity of flight, when once fairly on * Page 152. 
the wing, is exceeded by few, if any, of the feathered race. It is obvious that so short a space of time is by no means sufficient to occasion fatigue, and, still less, to lower the bodily condition, so as to affect the health of the bird.

But some may be ready to say, how know we that their flight is short? if they land on the west coasts, may they not have crossed the wide Atlantic, and taken their departure from America? The answer is decisive of the contrary, the American Woodcock being entirely different from the British species. Having said thus much, we think some light may be thrown upon this obscure subject, by examining the above facts, and comparing them with some others, which are equally well-known, about Woodcocks.

In the first place, their lean, poor, and often scurfy condition, is not owing to exhaustion from length of flight; because, not only those which are found on the eastern coast, are usually very weak and reduced, but even those which are killed in Norway, before the migration has taken place, are found to be already in an emaciated state, and infested with vermin. In a short time, however, after frequenting their favourite haunts in our country, they become fat and plump, and then, as the season advances, they usually fall off, and the flesh of those that have been accidentally met with in the summer, is found to be hard and dry. That their fatigue may be the consequence of this previous debility, is therefore not improbable; but it is not the cause. We will next touch upon their first appearance on our western instead of our eastern shores. It is a generally

VOI, It. 
prevailing opinion, that the state of the moon has much to do with the arrival and departure of Woodcocks; but more experienced naturalists have remarked, that the wind, and not the moon, determines the time of their arrival, which is usually in misty weather, during northerly or easterly winds. Supposing, then, that about dusk, and we know that the migrations of Woodcocks usually, if not invariably, take place at night, a flight of them starts from Norway, with a sharp northerly or easterly wind helping them, in adding to the natural velocity of their own most rapid flight, which has been estimated at one hundred and fifty miles per hour,-high up in the air, as we moreover know, they fly,-the land below them, when they had crossed the Channel, would be invisible, and, borne upon the breeze, by the time they had continued their flight till early dawn, where would they be? Look to the map, and w shall find them, after their flight, at the rate of one hundred and twenty, or one hundred and fifty, miles per hour, far away to the westward of Ireland, hovering over the Atlantic, steering for America ; and that they are found at sea, we learn from the most respectable authority. A Cornish gentleman, sailing at a distance from land unusual for birds to be seen, discerned a bird high in the air, which, gradually descending, alighted on the deck, and proved to be a Woodcock. During a heavy gale, two others sought shelter on board a line-of-battle ship, cruizing in the Channel; and a naval officer informed us, that, after a stormy night, several leagues to the westward of the Land'sEnd, when shaking the reefs out of the topsails, early in the morning, several Woodcocks were discovered in 
the rigging. With these premises before us, we think the mystery is, if not entirely removed, at least much lessened, and a first landing on the western shores of Ireland, and the Scilly Islands, fairly and easily accounted for ; the birds naturally, as day approached, sinking downwards to the nearest land.

That their flight, too, is rapid to the last, is further proved by many instances having occurred, of their killing themselves by flying against the glass of the Eddystone Light-house. Of their speed, indeed, some estimation may be formed, by one which struck against the plate-glass of a light-house on the coast of Ireland, and broke a pane, cast for the place, of unusual strength, viz., from $\mathrm{A}$ to $\mathrm{B}$ (A $\quad B$ B $)$, being more than three-eighths of an inch thick; the blow was so violent, that, in addition to the glass being broken, the bird was found dead, with its breastbone, and both wings, also smashed. Again, no less than five Woodcocks have killed themselves, in a similar manner, against the plate-glasses of the South-Stack light-house, in Anglesey.

There was a time when Woodcocks might be almost said to be as plentiful as Wood-Pigeons are now ; at least they abounded to such a degree, that catching them was a regular trade; and so late as fifty years ago, they were sold at the moderate rate of from six to seven pence a couple; but, like Starlings, Wood-Pigeons, and several other birds, they have, of late years, diminished in numbers.

As far as concerns Woodcocks, this, indeed, may easily be accounted for. In the first place, the demand, not for the full-grown birds merely, but for the eggs, has greatly increased in Sweden, where 
they are as highly esteemed, and therefore as diligently sought for, as Plovers' eggs with us. Thus, not a twentieth part of the former abundant numbers, may now be reared, and, of course, our annual winter supply must proportionably decrease. But other causes have operated, in this country, still further to diminish the number of those which, under former circumstances, might be inclined to come over,-namely, the great decrease of our woodlands; the improvements in agriculture, by which their haunts have been drained or broken up; and, lastly, the increase of population, which, more than we are aware of, deters shy and solitary birds from remaining in neighbourhoods to which they formerly resorted. It was a favourite amusement, in former days, to catch Woodcocks, by dozens, of a night, in places where now not a dozen could be taken in a whole season. Large openings were left, or rather made, in woods, which, at night, were filled up with wide-spreading nets, fastened by pullies to tall branches; a man stood concealed, on one side, with a rope running through the pullies, who, the instant he felt a cock touch the net, let it go, and, the net falling over the bird, secured the prize. In the fine old beech-wood which we have already more than once alluded to, numbers were formerly taken, in a wide space, still known by the name of the Woodcock-glade, where many a winter's night might now be spent unprofitably, and possibly without meeting with a single bird. Another mode of catching them was by springes,-a sort of trap, formed of an elastic stick, to which was fastened a horse-hair noose, put through a hole in a peg, fastened 
into the ground, to which a trigger was annexed; and, in order to induce the Woodcock to walk towards the noose, a little fence was extended on each side, by small sticks, set up close enough to prevent the bird passing between: these all met at the trap; so that, by this funnel-shaped fence, the Woodcock, in feeding, is compelled to pass through the narrow passage, with every chance of being caught by the legs. The elastic stick, in flying up, of course draws the noose quite tight, and effectually secures the Woodcock; but common horse-hair nooses will often answer the purpose, particularly if the little avenue fence is placed, to lead the birds to the snare. We remember seeing, in the south of France, a tolerably large fallow-field actually sown with horse-hair nooses, placed in straight lines, for catching Larks and other small birds; so closely were they set, that it was almost impossible for any small bird to alight in the field, and run a few feet, without being caught. The guiding avenue consisted merely of two small twigs, curved outwardly on each side; this external curve acting as a sufficient check to the bird's free passage, excepting along the line of snares. The labour of the person, who had given himself the trouble of setting them, was, we understood, amply repaid by the numbers taken by this simple process. We shall conclude what we have to say on the Woodcock, or, as it is scientifically termed, the Scolopax genus, by a few remarks upon one species, which was formerly an object of adoration amongst the ancient Egyptians, during life ; and, after death, was honoured with funeral rites equal to those bestowed upon their kings and princes, being entombed in 
sacred monuments, and still found, as mummies, embalmed with precious ointments and divers kinds of spices. It was to this bird that St. Paul chiefly alludes, in Romans, i. 23, when he accuses the Gentiles of changing the glory of the uncorruptible God into an image made like to corruptible man and to birds; and it was this bird, again, which formed part of the idol abominations alluded to, in the vision of Ezekiel. It is called the Ibis religiosa, or Sacred Ibis; and is peculiar to Egypt, and the countries bordering on the river Nile,-coming down from Ethiopia on the increase of the river; and from this circumstance is named, by the Arabs, Abou-mengel, (Father of the Sickle,) in allusion to the fruits of harvest, which are derived from the inundations of the Nile. It feeds on the smaller reptiles, and, as the Arabs still say, on serpents, which has by many been supposed the sole cause of its being worshipped by the Egyptians; but this appears doubtful, and we are inclined, with some other high authorities, to attribute their respect for it to another cause,-namely, a fancied resemblance to the moon, whether from the curved and crescent shape of its beak, or from the contrasted colours of black and white, which, in the opinion of an ancient writer* on the subject, made it appear as if marked with a crescent. Now the moon, as well as the sun, was a known object of worship amongst many of the heathen nations, and more especially the Egyptians. Thus Job alludes to it, when he says, If I beheld the sun when it shined, or the moon walking in brightness, and my heart

* Plutarch de Iside et Osiride. 
hath been secretly enticed, or my mouth hath kissed my hand; this also were an iniquity to be punished. -Job xxxi. 26, \&c. The reason why the Egyptians more particularly venerated the moon, was, because they considered it, in its crescent form, as bearing some resemblance to the boat or ark, in which Noah was preserved in the Flood, and, in their language, accordingly, they used the same terms for the moon and the ark.

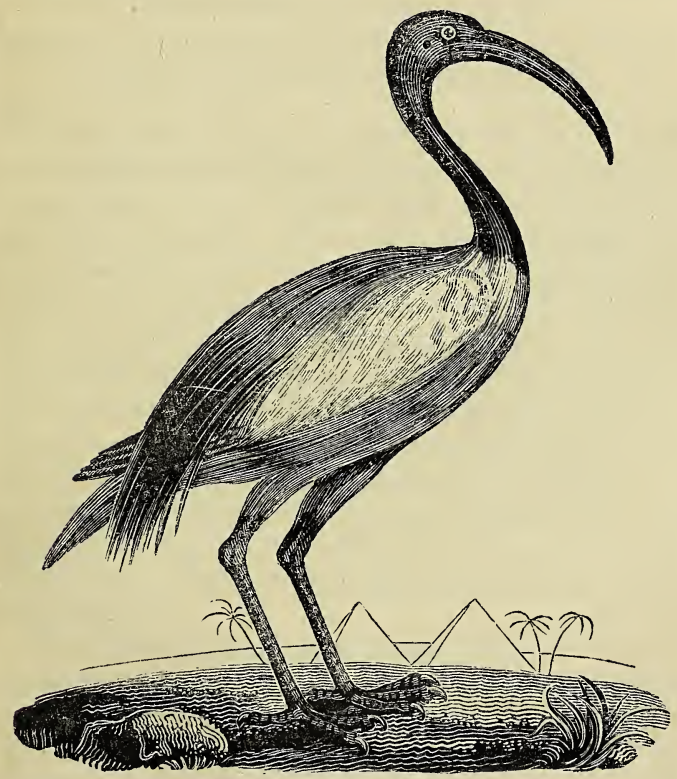

THE SACRED IBIS. 
Looking upon the Ibis, therefore, as a type or emblem of the moon, and again associating its appearance on the banks of the river Nile, at a season reminding them of the approach of those abundant crops produced by the inundations of their sacred river, we can easily see the reason why the priests of the country held it up to the ignorant people as a bird sent from heaven, and therefore to be worshipped in life and honoured in death. 
CHAPTER VII.

PALMIPEDES; WEB-FOOTED-SERRATED OR TOOTHBILLED. - GEESE ; FLOCKS OF-HOW MANAGED PLUCKING - SINGULAR ATTACHMENT - SAGACITT COURAGE OF.- TREE GEESE.- SWANS; MUSCULAR STRENGTH - COURAGE. - BLACK SWANS.-TRADE IN SWAN QUIXLS.

Table XXVI. (See vol. i., p. 22.)

Order 6. Paluipedes (Web-footed). Tribe 1. Serrirostres (or Tooth-billed). Table XXVII.

WE now come to the last order, consisting of those birds which are evidently calculated for swimming; having their toes connected with a web, extending nearly to the nails. There are, however, some few not classed here, although they are undoubtedly webfooted,-for instance, the Arosets and Flamingoes; but these, as has been already noticed, are not swimmers, their webs being of use only in supporting them, as they tread lightly over marshy grounds. The first genus is that of the Anas, comprising Geese and Ducks, whose beaks all, more or less, partake of the toothed or serrated character, represented in the plate of the Shoveller-Duck's Bill (vol. i., p. 34), for the obvious purpose of feeding in the manner there mentioned.

Notwithstanding certain points of resemblance, connecting Swans, Geese, and Ducks under one head, there are, nevertheless, some peculiarities in each, fully justifying the various subdivisions adopted by modern naturalists; by whom they have been, accord- 
ingly, separated into four sections,-Geese, Swans, and Ducks of two sorts, - one of which has the hindtoe furnished with a loose membrane; these latter chiefly frequent sea-shores or salt-marshes.

At the head of this list stands the Goose, and with reason, considering how valuable a bird it is, and how many benefits we derive from it in divers ways. Those who live in the fen countries of Lincolnshire look to the produce of their flocks, in the shape of quills and feathers, exclusive of the body considered - as an article of food, as a source of profit to them almost as great as the shepherd derives from his flocks and herds. These Geese are reared and protected with a care and attention of which those who have not witnessed it can form no conception.

It may, indeed, be doubted whether, under certain circumstances, Geese, in a profitable point of view, may not be considered as nearly equal to sheep. The latter, it is true, furnish a lucrative trade to weavers and manufacturers, as well as the farmer who feeds them; but the Goose affords no small item in the ledger of the upholsterer and the stationer, as well as the poulterer, in addition to thousands of acres of marsh land, which, but for this useful bird, would remain for ever worthless, or, at best, supply a scanty and precarious pittance. A slight sketch of the mode of managing a flock in Lincolnshire, may not be uninteresting. A single person will keep a thousand old Geese, each of which will rear seven; so that, at the end of the year, if fortunate in rearing, he will be possessed of seven thousand. During the breeding seasion, these birds are lodged in the same houses with their owners, and even in 
their bed-chambers; three rows of wicker pens are placed one above another in every apartment; each Goose having its separate lodge divided from the others, of which it keeps possession during the time of sitting. A person called a gozzard, attends the flock, and twice a day drives the whole to water, then brings them back to their habitations, helping those that live in the upper stories to their nests, without ever misplacing a single bird. They are, as we have observed in treating of Feathers (vol.i., p. 81), plucked frequently, we believe not less than five times a year; the first plucking being on Lady-day, for feathers and quills; the remaining pluckings, between that time and Michaelmas, being for feathers only. The old Geese submit with tolerable patience to this barbarous operation, but the young ones are noisy and unruly. Even goslings of six weeks' old are not spared; their tails being plucked, as it is said, to habituate them to future plucking.

When ready for the London market, flocks, from two to nine thousand in number, are sent off, travelling slowly from three in the morning until nine at night, during which time they will accomplish, on an average, about eight or ten miles.

Those who live near commons can turn the rearing of a few Geese to good account, and might reap still greater advantages if they paid due attention. If well kept, a Goose will lay not far short of one hundred eggs a-year. The French, who understand the management of poultry much better than we do, put their Goose-eggs under large hens of common fowls, in the proportion of from four to five eggs to each; and under Turkeys, to which they give nine or 
ten. When the Goslings are hatched, they are kept in a warm place for about four or five days, and fed on barley-meal, mixed, if possible, with milk, and then they will begin to graze.

Thus much for the attention due to the Goose for its pecuniary worth; but beyond this, it has qualities, we might almost say, of the mind, of a very singular character: we mean, the unaccountable constancy and affection which it has been known to show not only to its own species, and to other birds and animals, but more particularly to man. And it is not improbable, that these qualities, which, as we shall soon show, were known to the ancients, might have rendered it an object of high esteem, and even in some cases sacred, as, for instance, it was to Juno, the queen of their idol gods.

We shall briefly illustrate this part of our history by examples drawn from various sources, ancient as well as modern, corroborating them with a case which occurred in our own neighbourhood.

We have just mentioned, that this bird was held sacred to Juno, and we have good reason for supposing, that by the Gauls, an ancient and barbarous people, inhabiting the northern and western parts of Europe, it was held in almost equal estimation. How long this continued we do not know; but, at the time of the Crusades, that famous expedition undertaken by our ancestors in the reign of Henry the Second, about six hundred and fifty years ago, a Goose was carried as a standard at the head of one of those irregular bands proceeding from Europe to Asia, with the design of rescuing the city of Jerusalem from the hands of the Saracens. Of its 
attachment to the human race, Pliny, an ancient Roman writer, gives several instances; one only we select, as closely resembling that with which we shall conclude. A person named Lacydes, a philosopher, had a goose which took so strong a fancy to him, that it would never willingly leave him by night or day,--wherever he went, the Goose was his companion; if he went abroad and walked in the public streets, the bird followed him, and in his own house, always forced itself into his presence. The philosopher, struck with this constant and strange attachment, seems to have considered it as in some way or other connected with religious feelings, and, accordingly, when at last it died, he was at the expense of bestowing upon it a magnificent funeral.

Our next instance occurred in Scotland; a Goose, a year old, formed a similar attachment to a person in Elgin, and would follow him any distance, even through the crowd and bustle of the main street. One day, when going down this street, its master went into a hair-dresser's shop to be shaved, whereupon, the bird waited patiently till the operation was finished, and then accompanied him to the house of a friend, after which it proceeded home with him. Change of dress seemed to make no difference in the bird's powers of distinguishing its master, for in whatever dress he appeared, the Goose recognized him, and whenever he spoke, it responded by a cry expressive of satisfaction.

Another similar case is on record in Germany: an aged blind woman, who probably might have been in the habit of feeding it, used to be led every 
Sunday to church by a Gander, taking hold of her gown with its bill; when she had seated herself, it retired to graze in the church-yard till she came out again, when it led her home. One day, the clergy man called at her house, and, expressing his surprise to her daughter, that her mother should venture abroad, she replied,_- " $\mathrm{Oh}$, sir! we are not afraid of trusting her out of our sight, for the Gander is with her." We frankly own, that so strange and improbable do the above stories appear, that we should neither have inserted, nor paid them the slightest attention, had we not the following testimony to their credibility, for the accuracy of which we can vouch; and deeply do we regret, that a better fate did not await so extraordinary a bird, which, under more intelligent observers, might have afforded opportunities of ascertaining the extent of so unusual a development of affection.

A farmer in Cheshire possessed a flock of Geese, one of which, at the end of about three years, without any apparent cause, began to show a peculiar partiality for its master. It first appeared on the bird's quitting its companions in the barnyard or pond, and stalking after him. These symptoms became daily stronger, and in a short time, wherever the farmer went, whether to the mill or the blacksmith's-shop, or through the bustling streets of a neighbouring manufacturing town, the Goose was at his heels. So perseveringly did it follow his steps, that if he wished to go out alone, he was under the necessity of fastening up the bird.

The farmer was in the habit of holding his own plough, and on these occasions, the Goose as regu- 
larly passed the day in the ploughing field, walking sedately, not with the usual waddling pace of its fellow Geese, but with a firm step, head elevated, and neck erect, a short way before him, in the line of the furrows, frequently turning round and fixing its eyes intently upon him. When the length of one furrow was accomplished, and the plough turned, the Goose, without losing its step, adroitly wheeled about, and thus continued its attendance till the evening, and then followed its master home; and if permitted, would mount upon his lap as he sat by the fire after dark, showing the strongest signs of affection, and nestling its head in his bosom, or preening the hair of his head with its beak, as it was wont to do its own feathers. Sometimes the farmer would go out shooting, and no sooner had he shouldered his gun, than his companion was at its post, following him as before, in spite of every obstacle,- " "getting over," to use the man's own words, "the fences, as well as I could myself." All this, it should be observed, continued, not only without any encouragement on the part of the farmer, but even in spite of every discouragement on his part. How long it would have continued, or to what extent, we lament to add, he effectually precluded the world from knowing; for, with an unpardonable inattention to so truly a wonderful case, in addition to an equally unpardonable superstitious fear, he took it into his head, that this mysterious affection of the poor Goose foreboded some evil; and in a moment of alarm, he killed the faithful bird.

Thus much for the attachment of the Goose to 
man; and many equally striking instances might be adduced, of a similar attachment to animals. The two following anecdotes, show the mutual affection which may exist between this bird and the dog.

A species of the armed, or Cambrian Goose, a native of Africa, belonging to a person in Scotland, was observed for some time to pay particular attention to a dog which was chained up; and what was singular, this dog had invariably manifested a great dislike to poultry, never allowing them to come within reach of his chain. But in this case he laid aside all his former animosity, and received his new acquaintance with every mark of affection. The Goose finding she had nothing to fear from her canine friend, would enter his kennel,-in the centre of which, among the straw, she made her nest, and deposited her eggs, which was not known till one of the family mentioned that the Goose slept in the dog's bosom. The singularity of the circumstance led to an examination of the box (but not without the greatest reluctance on the part of the dog, who appeared determined to protect what was left to his care). On removing the straw, five eggs were discovered in a fine bed of down and feathers. The dog was in the habit of going into his box with the greatest care, for fear of injuring the eggs*.

A Canada Goose was also observed to associate itself, in a similar manner, with a house-dog; and would never quit the kennel, except for the purpose of feeding, when it would return again immediately. It always sat by the $\mathrm{dog}$, but never presumed to go into the kennel, except in rainy weather. Whenever 
the dog barked, the Goose would cackle, and run to the person at whom she supposed the dog was barking, trying to bite him by the heels. Sometimes she would attempt to feed with the $\operatorname{dog}$; but this was not allowed by the dog, who treated his faithful friend with as much indifference as the farmer above mentioned. The Goose would never go to roost at night with her natural companions, unless driven by main force; and, when in the morning she was turned into the field, she would never stir from the gate, but sit there the whole day in sight of her favourite. At last, orders were given that she should be no longer molested, but suffered to accompany the dog as she liked: being thus left to herself, she ran about the yard with him all the night; and whenever the dog went out of the yard, and ran into the village, the Goose as constantly accompanied him, contriving to keep up with the assistance of her wings; and thus, running and flying, would follow him to any distance. This extraordinary affection of the Goose towards the dog, which continued till his death, two years after it was first observed, is supposed to have originated from his having once accidentally saved her from a fox. While the dog was ill, the mourning bird never quitted him day or night, not even to feed; and it was apprehended she would have been starved to death, had not a pan of corn been placed every day close to the kennel. At this time she generally sat close by him, and would not suffer any one to approach, except the person who brought the dog's, or her own food. The end of the poor bird was very tragical; for when the dog died, she still kept posvoL. II. 
session of the kennel; and a new house-dog having been introduced, which in size and colour resembled that lately lost, the poor Goose was unhappily deceived; and going, as usual, within his reach, the new dog seized her by the throat, and killed her on the spot.

The Canada Geese appear to be peculiarly susceptible birds, and will, sometimes, make up by imagination or fancy what is deficient in reality. Thus, a Canada Gander in a nobleman's park, near Windsor, having no mate, has, for two Springs, regularly mounted guard opposite a drawbridge, in front of a thicket, where it is clear he imagines there is a nest, and defends the approaches very courageously, continuing this ideal defence till the first brood of ducklings appears from some other quarter, which he immediately takes under his protection; and last year he thus actually chaperoned twenty-five. It should be added, that there is no nest of any kind whatever within the precincts which he so strenuously guards.

But if, in this case, we may smile at the old Gander's fancy and credulity, in believing eggs to be hatching where none were laid, we can quote another, showing that a Goose is occasionally possessed of a keen sense, enabling her to detect imposition, and distinguish her own eggs from others closely resembling them. A Goose, belonging to a clergyman in Cheshire, was set (as it is termed,) on six or eight eggs. The dairy-maid thinking these too few, for so large a bird to cover, added an equal number of Duck eggs. The next morning she went as usual to see if all was right, when, to 
her great surprise, she found the Goose quiet on her nest, but every one of the Duck eggs picked out, and lying on the ground. Her mistress directed her to replace them, which was accordingly done; but the next morning, on going again to examine the nest, she found all the Duck eggis as before, moved off, and lying round about the nest; the Goose eggs remaining under the sitting bird in perfect order. How long she would have persevered in removing them is not known, as, for fear of driving the Goose from her nest, the experiment was not repeated.

When once attached to each other, they appear to be very constant; in proof of which, a person having marked five separate Ganders, and five separate Geese, with which they had paired, found that, for three successive years, when he attended to them, each regularly selected his companion of the former year, and continued faithful to her. Why the Goose has been so generally pointed out proverbially, as the most foolish of birds, it is difficult to say; for the above, as well as the following instances, would lead us to believe, that they are endowed with a larger, rather than a less, portion of sense, than other birds.

An old Goose, which had been for a fortnight hatching in a farmer's kitchen, was perceived on a sudden to be taken violently ill. She soon after left the nest, and repaired to an out-house, where there was a young Goose of the first year, which she brought with her into the kitchen. The young one immediately scrambled into the old one's nest, sat, hatched, and afterwards brought up the brood. The 
old Goose, as soon as the young one had taken her place, sat down by the side of the nest, and shortly after died. As the young Goose had never been in the habit of entering the kitchen before, the fact can only be accounted for by supposing, that the old one had some way of communicating her thoughts and anxieties, which the young one was perfectly able to understand. We give this anecdote on the authority of a Mr. Brew, who states it to have occurred at Finnis, in July, 1828.

So strong are the affections of these loving birds, that some who have exposed themselves to their rengeance, have occasionally found themselves fearfully worsted. A Game Cock, near Ashford, in Kent, priding himself, no doubt, on his prowess, happened, a short time ago, to take offence at a Goose, during the time of incubation, and, attacking her with great fury, pecked out one of her eyes, and destroyed several of her eggs. An old Gander, seeing the danger to which his mate was exposed, flew to her assistance, and many desperate battles took place. One day, in his absence, the Cock renewed his attack upon the Groose, when the Gander, hearing the bustle, hurried up, and seizing the Cock, dragged him into the pond, where he ducked him repeatedly, and finally drowned him.

Another somewhat similar instance occurred at Astbury, near Congleton, in Cheshire. Several Geese were feeding near a barn, where some men were threshing, and a Sparrow near them, when a Hawk suddenly pounced upon the latter, and would have inevitably carried it off, had not the Gander flown to its rescue, and, with his beak, struck the Hawk 
so violent a blow, that it was stunned, and taken up by one of the threshers. The Goose is, in truth, by no means a cowardly bird, and will often, when excited, defend himself very courageously; a quality of which the Russians seem well aware, as it is not an uncommon thing in that country, instead of training up Game Cocks for fighting, to have what are termed Goose-pits, where they are regularly trained for the sport. The birds are taught to peck at each other's shoulders, so as to draw blood; and welltrained Ganders have been known to sell as high as twenty pounds, and betting upon them runs very high. This cruel sport takes place in March*

Our domestic Geese are descended from the marsh or fen Goose (Anser palustris), whịch, though originally a wild species, is more easily tamed than some others, particularly if taken young. Not but that some of this race may be domesticated. In Ameriea, where vast flights pass to the northward to breed, the people shoot them in great numbers, and as many, owing to their wide spread of wing, are often merely pinioned, they are kept alive, and, in process of time, have been made so tame, that, having been let out in the morning; they returned in the evening. Several have been thus kept for many years; but although they constantly associated with the farm-yard Geese, they were never known to breed with them. Under particular circumstances, a wild Groose has indeed been known to throw itself under the protection of man. Thus, an officer settled on a farm near the Missouri, in North America, one day, when 
walking near the banks of the river, observed a large Eagle frequently darting towards the water, and then rising again. On a near approach, he perceived that its object was to take a wild Goose, which had alighted on the water, and which was diving to avoid so powerful an enemy. Its efforts, however, appeared to be vain, and, after diving again and again, and as often rising to get breath, it became nearly exhausted; when, suddenly turning, it made for the shore with all speed, towards the officer's house, where two men were at work; and as soon as it had landed, walked leisurely up to them, permitting itself to be taken, without attempting to escape. It was completely exhausted, but soon recovered, and, within three days, seemed quite contented and confident of protection.

Amongst other species of wild Geese, there is one called the Bernacle or Tree-Goose (Anas erythropus), which we shall mention on account of the extraordinary origin imputed to it, not only by ignorant, but even by some better informed people, in former days; and which may be adduced as one, amongst very many instances, of the advantages of knowledge, in separating truth from error.

It will scarcely be now-a-days believed, that this Bernacle, or Tree Goose, actually derived its name from a very general belief, that, instead of being hatched, like other birds, from an egg, it was produced from a shell which grew on trees and rotten wood; and the shell was, therefore, called, the goose-bearing shell (Lepas anatifera). For this foolish idea there was no other foundation than pieces of wood and decayed trees being often found 
in parts of the sea frequented by these Geese, all covered over with these shells, which seem to grow upon little stalks, and, as the feelers of the fish within it, are feathered, or fringed, they were supposed to be the downy covering of the young Goslings.

As a curious specimen of ignorant reasoning and credulity, we shall extract an account, written by the sage Gerard, as he was called, author of a wellknown book, called Gerard's Herbal, or History of Plants. This author was born at Nantwich, in Cheshire, and lived in the time of Queen Elizabeth. "There is," says he*, "a small island in Lancashire, called the Pile of Foulders, (on the west side of the entrance into Morecambe-bay, about fifteen miles south of Ulverston, ) wherein are found the broken pieces of old and bruised ships, and also the trunks and bodies, with the branches of old and rotten trees cast up there likewise; whereon is found a certain spume or froth, that, in time, breedeth unto certain shells, in shape like those of the muskle, but sharper pointed, and of a whitish colour, wherein is contained a thing in form like a lace of silke, finely woven as it were together; one end whereof is fastened unto the inside of the shell, even as the fish of oisters and muskles are; the other end is made fast unto the belly of a rude masse or lump, which in time cometh to the shape and form of a bird; when it is perfectly formed, the shell gapeth open, and the first thing that appeareth is the aforesaid lace or string; next come the legs of the bird hanging out, and, as it groweth greater, it openeth the shell by degrees, till at length

*Herbal, p. 1587. 
it is all come forth, and hangeth only by the bill; in short space after, it cometh to full maturitie, and falleth into the sea, where it gathereth feathers, and groweth to a fowl bigger than a Mallard, and lesser than a Goose, which the people in Lancashire call by no other name than a Tree-Goose; which place aforesaid, and all those parts adjoining, do so much abound therewith, that one of the best is bought for three-pence." So fully convinced was the sage Gerard of the "truth hereof," that he closes his account with an invitation to all who doubted the fact, to apply to him. "If any doubt, may it please them to repair unto me, and I shall satisfie them by the testimonie of good witnesses." These shells are represented in the annexed figure.

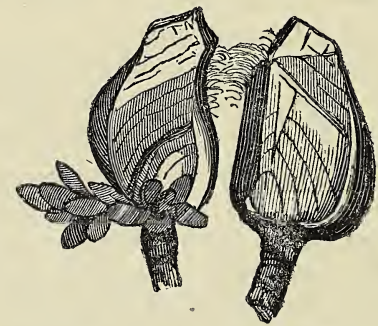

BERNACLE GOOSE-SHES.T. (Lepas anatifera.)

Of Swans we have three sorts : one our well-known tame species; the two others wild, called Hooper, Whooper, or Whistling Swans, from their loud, hoarse, and shrill cry, which has been expressed by whoogh, whoogh; but harsh as this cry is, it is far from disagreeable when heard at a distance, and 
moderated in the breeze. The Icelanders, whose year may be said to consist but of one long day of Summer months, when they enjoy the light of the sun, and one long night of Winter, when he never cheers them with his rays, compare this cry of the Wild Swan to the sound of a violin; and when heard at the end of their long and dreary Winter, announcing the approach of genial weather, it is associated and coupled in their minds with all that is cheerful and delightful. Any person who has seen a common Swan lash the water with its wings, as it flaps along the surface, or has witnessed the force with which it strikes a boat, when the rowers approach the female with her young cygnets, needs not to be reminded of the strength of its enormous pinions, and their consequent effect upon the air, enabling the bird to fly, according to the report of those who have watched the immense flocks passing to and from the lakes and rivers of the British settlements in Canada, at a rate of not less than one hundred miles an hour; a prodigious velocity, when we consider the size and weight of these noble birds. It is a prevailing opinion, amounting almost to a proverb, that a stroke of a Swan's wing will break a man's leg. How far this may be strictly true, we cannot say; but having once seen the pinion of an old Swan laid entirely bare to the very bone, and feathers and skin stripped off by an angry stroke on the gunwale of a boat, which it fiercely endeavoured to board, we think it not impossible. At all events, a blow of its wing can be inflicted to good and fatal effect, in case of necessity, as a crafty fox, wishing for a feast of Swan's eggs, found to his cost. The female was sit- 
ting on her nest at one side of a river, when she observed a fox swimming from the opposite shore: rightly judging that she could encounter the enemy with much better chance of success on water than on land, instead of retreating, she boldly advanced to meet him, and dashing forwards, so battered him with her wings, that he was soon killed, in the sight of several persons who saw the combat.

Besides the Swans above mentioned, there is another peculiar to Australia or New Holland, entirely black; but as they are tolerably hardy, it is not improbable that they may in the course of a few years be naturalized in England, and form an additional ornament to the rivers and lakes of our parks and pleasure-grounds. We have already noticed the peculiar manner adopted by young Coots for concealing themselves under water; and it has been ascertained, by those who have had opportunities of observing the habits of the Black Swan in its wild. and natural state, that although it cannot dive, it contrives to immerse itself so deep in the water as to render its body nearly invisible, and thus avoid detection.

We have already noticed the trade carried on in Goose quills; those of Swans being, of course, proportionably larger, and less common, are still in request, and preferred by some; consequently a considerable number find their way into the market, and fetch high prices. One of the principal sources of this trade is on the coast of the Black Sea, at its north-western extremity, in the neighbourhood of Kinbourn, a Russian fortress, nearly opposite to Oczakof, at the point of a tongue of land, deeply 
indented with creeks and bays and; as the country round is but thinly inhabited, wild birds abound. Amongst others, it is thronged with Swans, which select the long sandy headlands for the site of their nests. They assemble in numerous flights about these creeks, during the breeding-season. Aware of this, the people who collect their feathers, start in pursuit of them, the old birds being then busy hatching and breeding their young. The feathers are drifted on shore by the tide, and collected. The produce is sold to dealers, who come from the neighbouring towns of Oczakof and Cherson, and eagerly bid against each other. Sometimes the quills will fetch as much as three pounds per 1000, though the usual price does not exceed twenty-two shillings. They are also an article of trade amongst the people of the Crimea, who live near extensive morasses and marshes, as well as the peasants on the coasts of the Sea of Azof, in the direction of Marapot. 


\section{CHAPTER VIII.}

DVTK TRIBE-MANAGEMENT OF-CHINESE MODE.WILD-DUCKS BUILDING IN TREES-AFFECTION OF.EIDER DUCKS-HOW CAUGHT. - DUCK SHOOTERS.DANGER ATTENDING DECOYS.

IT would lead us far beyond our limits to notice all the Duck tribes, which are third on the generic list of this division; a few particulars must suffice. Much that has been said upon the treatment of Geese, applies equally to Ducks, which, under judicious management, might be made a source of great profit to the cottager; and we are assured, on the authority of a practical rural economist, that water is by no means indispenable; so far from it indeed, that instead of being absolutely necessary, it is often injurious to the young, and that, in fact, they should never be suffered to swim till more than a month old ; that, instead of allowing young Ducks to go out in the morning to eat slugs and worms, they should be kept up, since this food, notwithstanding their partiality for it, is injurious; and that grass, corn, white cabbages and lettuces, cut when half ripe, and flung down in the haulm or stalk, will make the finest Ducks for the market and the table. When young, they should be fed upon barley-meal, or curds, and kept in a warm place in the nighttime.

By attention and care, much more, we are persuaded, may be done in the general management, as well as improvement, of our domestic birds. We 
have been assured, for example, that the people in some parts of Buckinghamshire derive considerable profit from their peculiar skill in breeding and rearing Ducks. They contrive to reverse the order of nature, and, by a restriction of food, or other means, prevent them from laying till October or November. Some weeks before the time they wish them to lay, they feed them with stimulating food; and when the eggs are ready, they are put under a hen, who is obliged frequently to continue on the nest, till three successive broods have been hatched. When the young Ducks leave the shell, they are placed near a fire, and nursed with great care. By these means many Ducklings are sent at Christmas to London, where they meet with ready purchasers.

Of all people in the world, the Chinese are said to be the most skilled in the management of poultry, particularly of Ducks, many people at Canton earning their livelihood merely by bringing them up; some buy the eggs and trade with them, others hatch them in ovens, and others attend on the young ones. The following is their plan:They lay an iron-plate on a brick hearth; on this they place a box full of sand, half a foot high, in which the eggs are put in rows; the box they eover with a sieve, over which they hang a mat. To heat them, they make use of a particular sort of wood, which burns slowly and uniformly; at first, they give them but little warmth, increasing it gradually, and it becomes a strong heat by the time the eggs are hatched. If the heat is increased too much, the young Ducks are hatched too soon, and in that case they generally die in three or four days. The 
hatched young ones are sold to those who bring them up; and these try, in the following manner, whether they are hatched too soon or not. They take up the little Ducks by the bill, and let their bodies hang down; if they sprawl and extend their feet and wings, they are hatched in due time; but if they have had too much heat, they hang without struggling. The latter often live till they are put to the water, which is generally eight days after they are hatched,-this turns them giddy; they get cramped, throw themselves on their backs, and die in convulsions. They are carefully fed with boiled rice, mixed up with herbs and little fish, chopped small. When they are older, they are removed into a larger floating-pen, called a sampane, which has a broad bottom of bamboo, with a gallery round, above the river, and a bridge declining towards the water. An old and experienced step-mother is provided to lead them down, and attend them when feeding: these old birds are so well trained, that at the given signal in the evening, they return in the utmost haste with their young broods. This signal is a whistle, on the sound of which the whole flock sets itself in motion, waddling in regular order towards their boat. The first Duck that enters is rewarded with some favourite food; the last is whipped as an idler: so that it is a comical sight to see the last birds, as if knowing what will happen to the last of all, making efforts to fly over the backs of others, and get on board the boat in time to escape punishment.

We should be surprised to see our domestic Ducks perch amongst the branches of trees, adjacent to their roosting-places, and there pass the night; but 
though this seems impracticable for our species, there are, nevertheless, many others of the wild sort, that not only roost perching, but rear their young in trees. Captain Cook was surprised to find the Whistling-Ducks doing so, near Endeavour River in New Holland; and in various parts of the world, similar nests are found in these unexpected situations.

In America, the Anas sponsa, or Summer-Duck, builds in the hollows of trees, at a considerable height from the ground, from which the young ones, soon after they are hatched, descend and make the best of their way to the water. The Wood-Ducks, also an American species, are continually to be seen, during the breeding-season, flying between the upper parts of the Mississippi and the woods where they build. Our common Wild-Duck, in a similar manner (though according to the general habit of those birds whose young leave the nest as soon as hatched, she generally deposits her eggs upon the ground), at times departs from this practice, and follows the example of the above foreign species.

In Sussex, a nest was found in an oak tree, fiveand-twenty feet from the ground; the old bird was sitting upon nine eggs, supported by some small twigs, laid crossways.

In Derbyshire, a gentleman's game-keeper observed a Wild-Duck fly out of a large oak, in which the year preceding had been a Hawk's nest. On examination, she was found to have laid two eggs in the old nest, completely repaired.

Another instance occurred at Madeley, in Staffordshire. In this case, the Wild-Duck took possession 
of a Rook's nest at the top of an oak tree. The Drake was also seen to perch on a bough near her, and occasionally in her absence sat on the nest.

In the preserves of the Zoological Gardens, in the Regent's-park, London, we saw the nest of a Wild-Duck on the roof of a thatched cottage by the water side. The keeper was ordered to keep a good look-out, in order to see how the young ones would contrive to reach the ground; but they eluded his watchfulness by disappearing one morning, when he and his family were absent at church. It is, indeed, difficult to account for the exceptions to the accustomed habits of Wild-Ducks : we should suppose, that naturally they would prefer a convenient spot close to the water, and in such places their nests are usually built. Once, indeed, to our surprise, a nest was found in a patch of high grass, within a few feet of the spot where a boat was drawn up; and either so closely had the Duck sat, or so cleverly had she timed her visits to and fro, that it was not till after some time discovered by a carpenter who had been for three or four days on the spot, repairing the boat. But, from several other circumstances coming under our observation, we have reason to believe that they often build at considerable distances from the waters intended to be the permanent nursery for their brood. About a mile above this very sheet of water on which the boat was repairing, there is a hill covered with heather, fern, and plantations ; and more than once at early dawn, about four o'clock, in June, broods of little dark Wild-Ducklings, just hatched, have been seen trotting down the road, leading from the hill to 
the water; and once we were surprised, on a Summer's morning, at seeing about a dozen of these active little nestlings running before our door; so rapid were their motions, that, notwithstanding every exertion, they contrived to elude observation, till they were tracked in the grass to a small pit about two hundred yards off, in a meadow.

They no doubt had been making for the mere, or larger sheet of water, from the spot above mentioned, but had lost their way. There is one species, however, which in preference to trees or flat ground, selects a very unaccountable accommodation, namely, a rabbit-hole. This is the Sheldrake,-a bird by no means uncommon on many parts of our coasts. She selects, if possible, a burrow near the water, in which are laid sometimes sixteen eggs, which she carefully covers with the down of her body. The eggs may also be easily reared under hens, and the young ones may be kept in ponds. We have known several thus domesticated; but although many other species of Wild-Duck, under similar confinement, bred regularly, the Sheldrake never was observed to take any steps in preparing a nest.

In a nobleman's menagerie, we have heard, however, that they were induced to do so by simply burrowing holes about three or four feet deep, like rabbit-holes, in the bank, a foot or two above the water. The bird thus found her accustomed accommodation, and lost no time in availing herself of it. Ducks, too, like Geese, have a strong sense of affection: we cannot, indeed, produce instances so striking or so interesting as those related of the latter,

YOL. II. 
but the two following instances show a similar tendency towards animals as well as human beings.

A clergyman had a very fierce and noisy house$\mathrm{dog}$, within the length of whose chain it would have been dangerous for a stranger to have ventured; but, notwithstanding his apparently savage disposition, a brood of Ducklings, reared in the yard in which he was kept, soon became so fond of him, that whenever, from his barking, they apprehended danger, they would rush towards him for protection, and seek shelter in his kennel.

A farmer's wife had a young Duck, which by some accident was deprived of its companions, and from that moment seemed to concentrate all its affections on her. Wherever she moved, it followed her so closely, that she was in constant fear of treading upon and crushing it to death. As it grew older, its affection seemed to strengthen rather than diminish; it laid itself by the fire and basked on the hearth, and when noticed, seemed delighted: this continued till some other Ducks were procured, when, being constantly driven out of the house, it gradually associated itself with its more natural companions.

Another case was that of a pair of Muscory Ducks, which were landed at Holyhead, from a Liverpool vessel returning from the coast of Africa. The male was conveyed to a gentleman's house in the neighbourhood, and introduced to a flock of Ducks; but to them he manifested the greatest indifference, and was evidently pining at the loss of his mate, when one day, she too was brought up and turned loose; for a short time, being engaged at a distance, 
he did not see her; but, when, on turning his head accidentally, he caught a glimpse of his well-known companion, he rushed towards her with an earnestness and affection which quite touched those who witnessed the meeting. Nothing from that moment would induce him to quit her, and he manifested his joy at the unexpected reunion, by twining his neck on hers, - nestling it under her wing, and gazing at her with eyes expressive of extreme delight and satisfaction.

There is another Wild-Duck, deserving of mention from the value of the down upon its breast, which is carefully collected by those who rear these birds, and dispose of their produce at a very high price. The bird we speak of is the EiderDuck. And well may it have a warmer underclothing than most other Ducks,-born and bred, as it is, amidst the most dreary and desolate region of the Frozen Seas, and abiding either solitary, or in pairs near the ice, as far as possible from land, but assembling, at the breeding-season, in vast numbers, on most of the islands in the north. As Iceland is one of their favourite haunts, we cannot do better than collect our particulars from a spot where they are probably better known than anywhere else. There, as they are rarely hurt or disturbed, they become surprisingly tame, and allow persons to walk amongst their nests. On approaching them, the Drakes, indeed, often take alarm, and plunge with great precipitancy into the water; but the Ducks generally remain sitting on their nests, or merely fly to the distance of a yard or two, and on an attempt to 
touch their eggs, return in a rage. Many of them suffer themselves to be handled, and can only be removed by actual force from their nests. In some parts of the island, where they are more particularly attended to, they build their nests on the roofs of the houses, and become quite familiar with the inhabitants. The nests are constructed of sea-weed, and lined with the finest down, plucked from their breasts.

As soon as it is observed that the first eggs are laid, they are removed, and the nests at the same time robbed of the down; and this is repeated a second or a third time; but it is generally found, that if they are robbed more than twice, they begin to desert the place, and if pillaged oftener, they quit it entirely.

A few days after the young Ducks leave the egg, they proceed to the water, under the guidance of their dam, who swims with them on her back to some distance, when, making a sudden dive, she abandons them to themselves, and re-appearing, tempts them to come towards her; so that, on the first trial, they commonly become expert swimmers. When the breeding-season is over, they generally stand out to sea; yet numbers are seen frequenting the bays and creeks about the coast.

The eggs furnish excellent food to the inhabitants, and the down is bought on the spot at about thirteen or fourteen shillings a pound, by merchants, who send it to different parts of the world. It is used chiefly for making bed coverings, on account of its exceeding lightness as well as warmth; a large bedquilt, sometimes weighing only five pounds three 
ounces; of which the linen covering weighs two pounds and a half,-leaving two pounds eleven ounces for the Eider down.

Shy and difficult of approach as Wild-Ducks are, and withal so valuable when obtained, we ought not to be surprised that a good deal of human ingenuity has been exerted in inventing the most efficacious modes of catching them; and, it is curious to perceive how people in very different parts of the world may hit upon the same expedient. Thus, the Indians, who live in villages built on the shallows, in the midst of the waters of the great lake of Maracaibo, on the north coast of South America, opening into the Caribbean Sea, practise the same mode as the Chinese. They take care that a number of empty calabashes, a sort of large shell, or rind of a fruit, resembling an empty gourd, are continually floating up and down the lake; to these the Ducks get accustomed, and allow them to drift down amongst their flocks without expressing any fear. The Duck-catcher, particularly when from the state of the wind or situation of the birds, he observes the calabashes floating near a flock, goes into the lake, with a calabash over his head, having holes in it for seeing and breathing. Nothing is seen above the water except the calabash, the Indian taking care to keep the whole of his body immersed. He now steals slowly and quietly towards the unsuspecting birds, and when within arm's length, catches one of them by the leg, and twitches it suddenly under water, before it has time to alarm the rest, by crying or fluttering its wings: He then moves towards another, which he treats in 
the same way, and so on, till he has collected as many as he can conveniently carry, attached to a belt round his middle, and then he slowly retires, leaving the floating calabashes amongst the Ducks. On another part of the coast the same expedient is practised, excepting that, instead of a calabash, they use a sort of cap made of rushes, similar caps being left to float amongst the flocks of Ducks, to which they soon get as much accustomed as those we first mentioned do to the calabashes.

The Sheldrakes, which, as we have seen, build in rabbit-burrows, are caught by snares placed before the hole, into which the birds are traced by the marks of their feet on the sand. In this country, our markets are supplied either by those who are in the habit of shooting them, as a livelihood during the winter season, or from decoys, in which by far the greater number are taken. In shooting, the great difficulty is to get within gun-shot, the Duck not only being very watchful and timid, but possessed of so fine a sense of smelling, that but for the precaution of approaching them to leeward, or of holding a piece of smoking turf in the hand, it is no easy matter to get within reasonable distance. The guns, also, which are employed for this purpose, are much longer than those in common use, and will kill at a much greater distance. A Duckshooter's life is often exposed to great hazard; the sport, if so it may be called, being carried on usually in Winter, late in the evening, or early in the morning, and most frequently in wet and marshy places, or on the shores of wild and solitary estuaries, opening through the lowlands near the sea. On these occa- 
sions, some of them prefer going without even a dog, the cold being often so severe, that no animal could bear it.

Many of the favourite feeding places consist of those vast muddy flats, covered with green seaweed, over which the fowler must slip and slide in the best way he can, or (were it not for his mudpattens, flat square pieces of board tied to the feet,) through which he might sink up to the middle waist.

On one of these expeditions, a Duck-shooter, in Hampshire, met with a perilous adventure. Mounted on his mud-pattens, he was traversing one of these oozy plains, and being intent only on his game, suddenly found the water rising with the tide. Aware of his danger, he looked round, but his retreat was already cut off; he was already surrounded with the flowing sea, and death stared him in the face. But in this desperate situation his presence of mind remained, and an idea struck him, which might yet be the means of his preservation. He gazed round to see if any part of this mud desert was higher than the rest; and observing a small portion still a foot or two above the water, he hastened towards it; and when there, striking the barrel of his long gun deep into the ooze, he resolved to hold fast by it, as a prop to secure himself against the buffetings of the waves, which were breaking angrily around him, and had now reached his feet; and at the same time, as an anchor, to which he might cling, and not be carried away by the current of the flowing or ebbing tide; or, at all events, that if it was to be his sad fate to perish, 
his body might be found by those friends who might venture out to search for him. Well acquainted with the usual rise of the tide, he had every reason to suppose that it would not reach above his middle, and that if he could endure the cold of six hours' immersion, he might be saved. Unfortunately, however, he had not taken into account the state of the wind, or some other causes, which had not only brought the waters up more rapidly than usual, but would also add to their height. Accordingly, having first felt the chill and deadly sensation of ripple after ripple, now covering his feet, then bathing him knee deep, and then advancing beyond his waist, he was horrorstruck at finding, that instead of receding, it still crept upwards, and had reached his shoulders; the spray burst over his head: upon another minute's rise or fall of tide, his life depended; but still, though he gave himself up for lost, he firmly grasped his gun-barrel. The main land was too far distant to admit of his shouts being heard, and it was equally vain to hope, that any looker-out could descry such a speck upon the waves as the head of a human being. In this awful moment of suspense, on looking downwards, he thought he saw the uppermost button of his waistcoat beginning to appear. Intensely he watched it, but for some time without any well-founded assurance that he was right. At length, however, hope increased to certainty, as he saw button after button rising slowly into view, an infallible sign that the height of the tide was over, and that it was now upon the ebb. Though chilled with cold, and almost fainting, this 
welcome prospect raised his spirits, and, acting like a cordial, enabled him to endure the remaining hours of his fearful imprisonment. This man escaped; but we well remember a case very similar, in which the poor sufferer had to endure an equal horror, though not spared to tell the tale.

Off the north-west point of the hundred of Wirral, in Cheshire, extends a wide tract of sand, forming a dangerous shoal, called Hoylebank, which has proved the grave of many a shipwrecked mariner. To this bank, always dry at low water, the fishermen of the neighbourhood are in the frequent habit of going to collect muscles. One evening, a party having ventured as usual, before separating, agreed upon a particular point where they were to meet again when the tide began to come in. Dusk came on, and those who first returned to the boat rowed to the appointed rendezvous, there to await the arrival of their comrades; but hour after hour passed, and some were yet missing. The boat-keepers began to fear the worst ; the absentees had either lost their way on the wide desert of sand, and were now wandering about hopelessly in darkness, or they had perished in one of the many quicksands which abounded on the shoal. Still they hung upon their anchor, and waited till at its appointed hour the tide had covered the whole bank, and not a doubt could remain as to the fate of their friends. They then returned to reveal the sad tidings to their relatives on shore, and at early dawn repaired once more to the bank, now dry as when they first landed. One body alone was found, and he, like the Duck-shooter, had resorted to the 
same last and forlorn hope. He had firmly fixed a boat-hook on the highest ridge of sand, and having lashed himself to it with his handkerchief, had determined there to await the rising of the last tide he was ever destined to behold. The bodies of his companions were never seen again, and had probably found a resting-place in the deep channels of the surrounding sea.

Not far from the scene of this sad story, on the Cheshire side of the mouth of the river Dee, runs a ridge of three small rocky islands, called Great Helbree, Little Helbree, and at the southern extremity, at a somewhat greater distance, forming the termination of the ridge, the Little Eye. At low water, the passage between these rocks and the main land is entirely dry. At this time, therefore, those who were inclined to take the chance of one single shot, for a second loading was out of the question, bent their way to the Little Eye, and took possession of a sort of excavated hovel, where, under cover of a few rough stones piled together, they were prepared to remain till high water; when, if they were fortunate (but this was by no means to be calculated upon with anything like certainty), a floating flock of Ducks and other sea-fowl would drift within reach, and a well-directed fire might do prodigious execution.

We have heard of we know not how many dozens of birds killed or disabled by this solitary broadside: whether the birds have retired from this part of the river, or the patience of the Duck-shooters has been exhausted, we cannot say; but of late years the sport seems to have been discontinued. 
In the south of England, this mode is howerer still practised. On the coast of Hampshire, the marksman conceals himself till night, and then, listening with attention, directs his course towards the spot on which a flight of sea-fowl has descended to feed: when he judges himself sufficiently near, he directs his piece and fires at a venture, and instantly catching up another gun, discharges it where he supposes the flock to be rising on the wing; he then hastens to the spot with his mud-pattens, and gathers up the profits of his toil.

We suspect, indeed, that the birds have seceded from the whole line of the river Dee; for the flights now seen are not to be compared with those which are spoken of as frequent a few years ago, when a couple of experienced Duck-shooters, we believe from the fens of Lincolnshire, spent some weeks on the coast, and realized a considerable sum by supplying the Chester and Liverpool markets. Their plan was this:-One of them had a small flat-built boat, without any keel, about sixteen feet long, and three feet broad, drawing about three and a half inches water. It was managed by a pole twelve feet long, made about six inches broad at each end, which the man held in the centre, and dipping each end in, propelled his boat along; and when he got near his prey, used two small paddles, only three feet in length, by which he guided his skiff. His gun, which was fixed on a rest, consisted of two immense barrels, about nine feet long, an inch and a quarter in diameter, requiring three quarters of a pound of powder and two pounds of shot to load both barrels, which were fired together. His success in one week 
was a hundred and three Ducks, and eleven Geese, besides smaller birds. At one shot he had been known to kill two hundred and one Sea-Purres. He earned about ten pounds per week, and his companion rather more by a similar plan.

But the exploits of our British fowlers are insignificant when compared with the grand scale on which this warfare is carried on in Mexico, where a great Tiro de Patos, or Duck-shooting, is, we are assured $\%$, one of the most curious scenes that it is possible to witness. The Indians, by whom it is principally conducted, prepare a battery composed of seventy or eighty musket-barrels, arranged in two rows, one of which sweeps the water, while the other is a little elevated so as to take the Ducks as they rise upon the wing. The barrels are connected with each other, and fired by a train; but the whole apparatus, as well as the man who has charge of it, are concealed in the rushes, until the moment, when, after many hours of cautious labour, one of the dense columns of Ducks, which blacken at times the surface of the lake, is driven by the distant canoes of his associates sufficiently near to the fatal spot. The double tier of guns is immediately fired, and the water remains strewed with the bodies of the killed and wounded, whose escape is cut off by the circle of canoes beyond. Twelve hundred Ducks are often brought in as the result of a single attack; and during the whole season they form the ordinary food of the lower classes in the town of Mexico, where they are sold for a trifling sum.

We have alluded to decoys as the great source of 
profit and supply with respect to wild-fowl; and with an account of them we shall conclude the history of Ducks. A decoy is generally situated in a marsh, so as to be surrounded with wood or reeds, and if possible, with both, to keep the water quiet, and that the repose of the wild-fowl may not be interrupted. A certain number of Decoy-Ducks is then provided, consisting of wild ones, which are bred for the purpose, and which, although they fly abroad, regularly return for food to the decoy-waters, and of tame ones, which never quit the water, and are regularly trained to act their part. Their food consists of hemp-seed, oats, and buck-wheat. In what is called working the decoy, the hemp-seed is thrown in small quantities over screens, made of reeds, to allure the birds forwards towards the pipes, or wicker channels, of which there are several, leading up a narrow ditch, closing at last with a funnel-net. Over these pipes, which grow narrower from the first entrance, is a continued arch of netting suspended on hoops; it is necessary to have a pipe for almost every wind that can blow, as upon this circumstance it depends which pipe the Ducks will take to; and the decoy-man always keeps to leeward of the flock, taking the additional precaution of keeping a piece of turf burning to prevent their scenting him.

Along each pipe, at certain intervals, are placed the reed screens, which hide the decoy-man, until the moment when it is necessary for him to show himself, namely, when the birds have passed up the pipe to which they are led by the trained birds, who know the whistle of the decoy-man, or are enticed by the 
hempseed. A dog, which is generally preferred of a reddish colour, is also trained to play backwards and forwards between the screens; and by suddenly appearing, and running round a screen, the birds are attracted towards him. When a sufficient number of Ducks have thus fairly passed up the pipe, the decoy-man comes forward from behind the screens, upon which the whole flock, unable to fly upwards on account of the hoop net above, rush onwards to a funnel-net which opens on the land, where they are caught without difficulty; the trained birds are of course immediately turned loose again. If well managed, a good decoy has heen known to produce several hundred pounds a-year. 


\section{CHAPTER IX.}

PINNIPEDES; SWIMMING FEET.-PELICAN - FABLE OF DRAWING ITS BLOOD EXPLAINED-MODE OF FISHING.-SEA-BIRDS FEEDING ON FISH THROWN UP BY WHALES. - CORMORANTS-VORACITY OF - MAY BE TAMED - FIERCENESS OF.-FRIGATE BIRD.-SOLAN GOOSE-LIGHTNESS AND BUOYANCY OF-NESTS.AUHINGAS OR DARTERS.

TABle XXVIII. (See vol.i., p. 23.)

Order 6. Palmipedes. Tribe 2. Pinnipenes (Swimming-feet).

The birds of this 'Table are, like the preceding, webfooted, but they differ from them in having the back-toe so united with the others as to form one continuous web, having, in some instances, a toothed claw on the second toe; and what is very

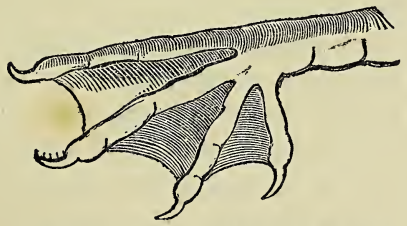

TOOTHED CLAW OF CORMORANT'S FOOT.

singular, notwithstanding this peculiarity, which, it might be supposed, while it rendered them more fit for swimming, would entirely prevent their clinging 
to a branch, almost all of them can and do frequently, perch on trees.

The Pelican stands at the head of this list, easily distinguished from all others by his capacious pouch, formed of a naked skin, stretched, or rather suspended from the two bony branches of his lower mandible. We have already given his picture, in speaking of the pouches peculiar to some birds.

Few birds have had more marvellous stories told of them than the Pelican, and most of them founded upon some peculiarity, exaggerated by the ignorant. Thus, the old tradition of its drawing blood from its breast to feed its young ones, or as some ancient authors gravely asserted, to bring them to life again, after serpents had squirted venom into the nest and destroyed them*, originated in the bird's habit of pressing its beak to its breast, in order more easily to disgorge the food it had prepared for them. They have again, by others, been considered as purveyors of water to the camels, who instinctively seek in the desert for nests of these birds, which form reservoirs of water, conveyed thither in their pouches, to quench the thirst of their young. True it is, that the pouch of the Pelican is capable of carrying about two gallons, but it is for the conveyance of fish rather than water, that it is serviceable to the bird; and were it ten times more capacious, the dry and parched sand of the burning desert would soon suck up a supply so insignificant for an animal which, at one draught, would take up the water imported by a flight of Pelicans.

But without going into fabulous history, this bird has true wonders enough to excite our admiration and

* Eusebius on Psalm cii. 
astonishment. Looking at his vast dimensions, six feet from the point of the bill to end of the tail, we should suppose that there would be a corresponding weight to be borne upwards by its vast, spreading wings, twelve feet from tip to tip, and yet its entire skeleton does not weigh much more than thirty ounces, its bones being so light as to be nearly transparent. It possesses also in a high degree the capacity for containing air, already spoken of*, when we treated of the lightness of some birds; its bones and feathers, as well as the space between the skin and the flesh, being all reservoirs of air. Thus furnished, the Pelicans will frequently, like the other air-supplied birds, rise to an immense height. In one respect, indeed, this lightness operates against its procuring fish; for so large a surface, of so light a weight, cannot easily be forced under water.

The Pelicans, aware of their inability to catch their prey under water, in consequence of this buoyancy, adopt an equally certain mode of supplying themselves; for, assembling in flocks, they unite their forces, and surrounding a shoal of fish, strike the water with their wings; and with the noisy splashing, frighten and drive them into a narrower compass, so that the shoal at length becomes much compressed: the upper part is thus raised by the lower, when, at a certain signal, all the Pelicans strike the water again, and in the general confusion fill their pouches, and devour the contents at their leisure.

The Russians, who have ample means of observing their habits, owing to the immense flights arriving annually from the Black Sea and the Sea of Azof,

$$
\text { * Vol. i., p. } 63 .
$$

VOL. II. 
and alighting at the mouth of the river Don, assert that the Pelicans take the Cormorants into partnership on these occasions; the Pelican extending its wings and flapping the water, while the Cormorant, diving below, drives the fish to the surface; and when, by their joint exertions, the shoal is driven into the shallows, and easily taken by the Pelicans, the Cormorant helps himself out of his companion's wide pouch. The very respectable writer*, on whose authority we state this latter part, gives some further account of the concealment of their eggs, which, however extraordinary at first sight, is so well borne out by the instinctive habits of some other birds, that there is no reason for doubting its truth. He says, that if disturbed while sitting, they will hide their eggs in the water, taking them out with their bills when they believe the danger to be over.

We can vouch for the fact of sea-birds feeding on fish, forced above the surface by the lower part of the shoal, having witnessed a singular scene off the Hebrides during the herring season. A whale of the smaller species (Delphinus deductor + ) was observed pursuing a shoal of herrings about half a mile off. The fish were evidently in a state of alarm, and it was equally evident that a prodigious flight of Gulls, Gannets, and all the host of seabirds, were aware of what might happen, as they hovered over the spot screaming, and now and then

* Dr. E. D. Clarke's Travels.

+ The northern coasts were much frequented by this whale about that time; at Kirkwall Bay in Orkney, we saw the remains of no less than ninety-two, which had been recently driven on shore in a heavy gale. 
darting irregularly downwards to within a yard or two of the surface. As the whale closed upon the shoal, agitation seemed to increase, judging by the increased excitement of the birds above. His long black back slowly rose, and disappeared as the huge animal rolled onwards, seldom descending so far below as to bury his back-fin, which rippled along the surface : at length he was in the midst of them, and the confusion was complete. At one moment he disappeared altogether; but though unseen by us, it was very clear, by a momentary elevation of an actual mass of herrings above the water, that the poor frightened creatures had closed within the smallest compass, and by the upheaving struggles of the lower stratum of the shoal, were thus unwillingly exposed to greater dangers in another element; for, availing themselves of this eventful moment, down came the birds with one simultaneous pounce upon the dense mass. Shortly after, the dark fin would again appear, and a bright jet of glistening foam, rising like a fountain, announced that the animal was under the necessity of breathing or blowing after his labours. Then again he would descend headlong, with a sort of recruited spring, exhibiting nearly his whole body, and giving the water a tremendous lash with his tail as it disappeared. The sound produced by this crash upon the waves was astounding enough in itself, but the effect of the blow was far more so; for, whether by a sort of sculling motion, it scooped and threw a mass of herrings upwards with a jerk, or whether they were fairly driven from the water with the cloud of foam which 
followed the blow, the air for some feet above the water was spangled with bright specks of herrings, on which the united host of birds again pounced, forming one mingled mass of herrings, sea-fowl, and foam.

In the West Indies, it appears that some of the species of Pelicans are able to immerse their bodies; and, after diving and bringing up their pouches full of fish, will good-naturedly allow the parasite Gulls (so called from being in the habit of living on the labour of others,) to settle on their heads, and partake of the spoil*; a fact, in great degree corroborating the Russian account of the Cormorants, just mentioned. If the Pelicans of the West Indies permit themselves to be made into resting-places for other birds, those of the Eastern world consider themselves equally privileged to make restingplaces for themselves on the bodies of animals. On the banks of the river Tigris in Asia, the favourite resort of a species of Pelican (Pelicanus fuscus), they may be seen in great numbers, spreading their silvery wings, quietly settled on the backs of the buffaloes, which are plunging into the water, and patiently accommodating themselves to this incumbrance*. We know that cows will allow of Magpies sitting on their backs, and pecking holes in their hides,-for which they ought to be grateful, as the Magpie is doing the poor beast an essential service, by ridding it of the grub of the Gad-fly (cestrus bovis), the sound of even one of which will send a herd off at full gallop, with their tails in the air;

\footnotetext{
* Transatlantic Sketches.

+ Mignan's Travels.
} 



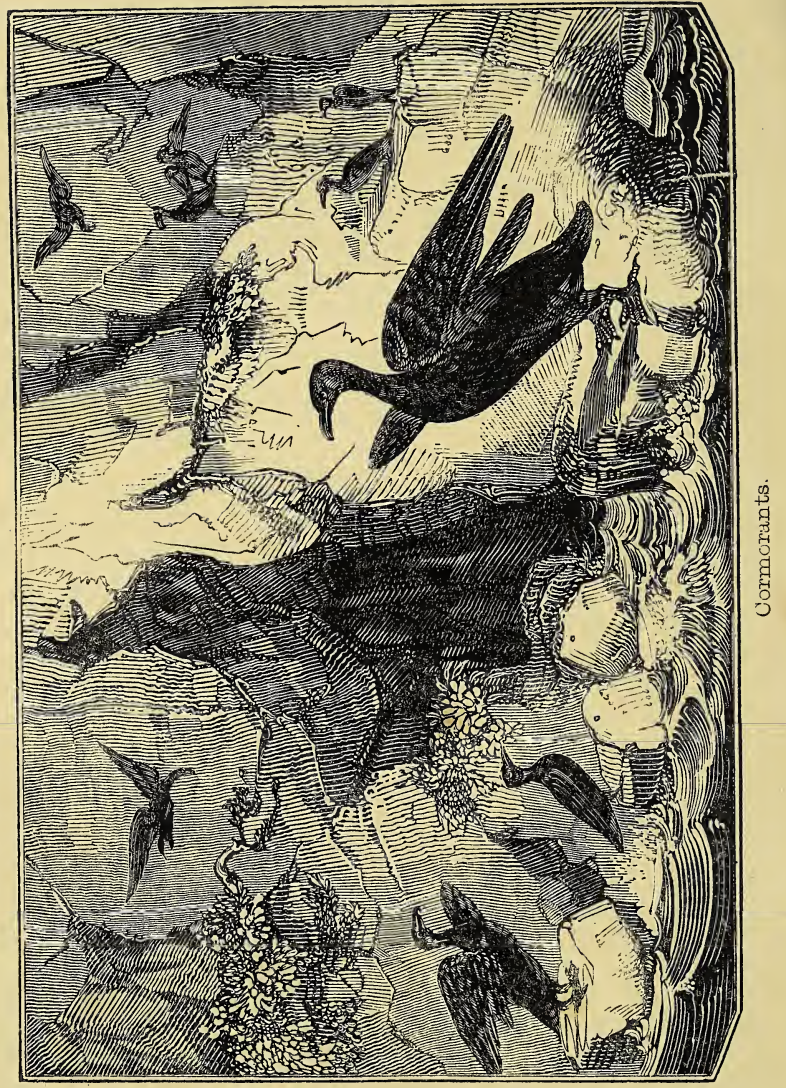


but as the Pelican's beak is by no means fitted for boring into the tough coat of a buffalo, we cannot account for the apparent satisfaction expressed by the animal on its making this settlement.

Of the voracity and capacious stomach of the Pelican, as well as of his pouch, we have spoken before (vol. i., p. 52.) Of this the Chinese take advantage, and train a species of Pelican or Cormorant, called by them, Loo-fou, as fishing birds. The fisherman fastens an iron ring round the bird's neck, so that it cannot swallow. Thus prepared, he sits quietly in his boat, till he sees a fish, when the bird is immediately tossed into the water. Its quick eye instantly perceives the game, and as instantly does the bird dart after it. On rising, the boatman opens the pouch, and taking out the fish, waits for the appearance of another.

To the Pelican succeeds the Cormorant; so closely, indeed, are they allied, that many naturalists have classed them together, and given them the same scientific name; for instance, our common Cormorant is called Pelicanus carbo. The Cormorant, however, may be distinguished by the claw of the middle toe being indented like a saw*, probably to help him in retaining the slippery bodies of small fish, as the toothed claw of the Herons serves for a similar purpose. Possibly. it may further serve so awkwardly-shaped a bird, by enabling it to cling to branches; for, although they usually frequent rocks and precipices, they can, and very often do, perch on trees. The poet, Milton, seems to have been aware of this, when he describes Satan taking the

* See figure, inserted in vol. ii., p. 131. 
form of this ill-favoured bird, when he first entered Paradise, devising the ruin of our first parents :- Up he flew, and on the tree of life Sat like a Cormorant-devising death To them that lived.

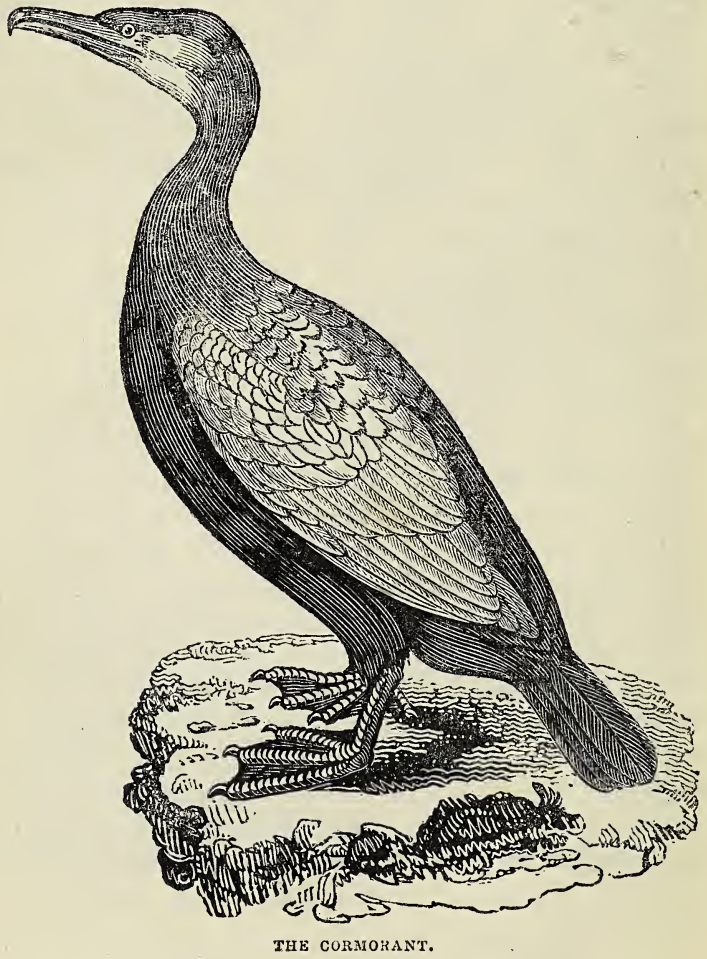


The poet could not, indeed, easily have selected a fitter frame for the foul fiend than that of a Cormorant: there is something so unearthly about him, as he is seen reposing on a rock when gorged with food; his slouching form, his wet and vapid wings dangling from his sides to catch the breeze, while his weird, haggard, wildly-staring emerald-green eyes scowl about in all directions.

The quantities of fish one of these birds will devour is astonishing - three or four pounds a day, or about half their weight, - a Cormorant weighing from six to seven pounds. What should we say of a man's eating seventy or eighty pounds of beef or mutton at his daily meals? which he would do were his appetite as great in proportion as that of the Cormorant's. The fact is, that, like most birds living on fish, its digestion is extremely rapid, and it therefore requires a proportionably larger supply of food, of which if it is deprived, it soon dies, as is often known to be the case. Thus, on the western coast of the Hebrides, these poor birds suffer severely, when, during and after a continued gale, the Atlantic rolls in its enormous billows, dashing them against the headlands, and scouring with their fury the sounds and creeks. As far as the eye can reach, the ocean boils and heaves, presenting one boundless field of foam, the spray from the summits of the wares sweeping along the waste like drifted snow: no sign of life is to be seen, save when a Gull, labouring hard to bear itself up against the blast, hovers over head, or darts by like a meteor. If, at such a season, the haunts of the Cormorants are visited, they will be found huddled 
together in their caves and crevices, perishing with hunger, and their numbers daily thinning by death. If, indeed, they could venture out, and bear the buffeting of the storm, they would still fail in procuring food; for, as in fishing, these birds always carry their heads under water, in order that, with their keen, clear, and beautiful eye, they may discover their prey at a greater distance, it is obvious that in such commotions of the air and water, they would need even a quicker glance than they possess. The use they make of their bill in feeding shows remarkable ingenuity, as well as agility: if the fish happens to be a flat one, a flounder for instance, they will turn it, so as to place it in the most commodious position for slipping down the throat; if, on the contrary, it happens to be an eel, which has been seized in an unfavourable position for gorging, they will throw it up, as a cook does a pancake, and catch it in the fall.

Wild and desolate as are the habitations of these birds, and little as they seem to have in common with man, yet, judging from one which was caught young, and reared, they are not only docile, but grateful and affectionate. This bird *, though it had fasted twenty-four hours, during its journey by coach to the place where it was sent as a present, refused every sort of food. It was, therefore crammed with raw flesh, as no fish could be procured. It submitted patiently to this forced meat, and was left by the gentleman, who retired to his library after seeing it fed, but who was not a little surprised, in a few minutes, to see the bird walking boldly into the room, and, when before the fire, beginning

* See Montagu's Ornithol. Dict. 
to plume its feathers, as much at ease as if seated on its native rocks. It was removed to a menagerie, and supplied with water, into which it immediately plunged, and manifested much restlessness, as if disappointed in not finding fish. After this it gradually became more docile, and fed upon whatever was offered; and, if let out, never attempted to ramble, but walking direct to the house, would enter the first open door, without caring either for men or dogs; and, in short, at last becoming troublesomely tame.

This is fully corroborated by another account of a couple of these birds, which were brought up from the nest, and kept for nearly two years. The owner found them pleasant pets enough, unless when pressed by hunger, when they became quite outrageous, and screamed violently. But woe to the man or animals that ventured to approach them when hungry. One day a gentleman's servant went in to look at them, wearing, unfortunately for himself, a pair of red plush breeches, which immediately caught their attention, mistaking them, probably, for raw flesh, as they had been accustomed to be fed on raw liver and lights, resembling the plush, in some degree, in colour: the consequence was, they made such a furious charge, that the owner was obliged to come to his assistance with a stick, and even then could not keep them off without much difficulty. Their attack on dogs, cats, and poultry, if unprotected, was always fatal. They fought at once with their bills, wings, and claws, screaming frightfully all the time. They were on this account at last parted with, having killed a favourite pointer. The poor dog had 
incautiously strayed into the place where they were kept, when they immediately flew at him, and attacked him in front and rear: his loud howlings brought his master to his aid, but too late; they had got him down, and inflicted fatal wounds.

The chief difference between Cormorants and the Frigate-birds, so called from their keeping a sharp look-out on other birds, and robbing them of their fish, consists in the latter having forked tails like our Swallows ; their spread of wing is also proportionably much larger, and they are altogether of a lighter and more elegant appearance. We know but little of them; indeed, our knowledge is limited to one species only, the Tachypetes Aquila, of which we have already spoken (see vol. i., p. 95, when considering the buoyancy of birds and their power of floating in the air. We shall, therefore, proceed to the next genus, Gannets, or Boobies, as some of them are called by sailors, owing to the stupidity with which they suffer themselves to be attacked and robbed by men and birds.

The common Gannet (Solan Goose) is the species to which we shall confine our remarks: well known as it must be to those who have sailed on either side of the Scottish coast, as well as several other shores of our island, it will be more familiar to many, under the name of the Solan Goose. Like most of the other birds of this tribe, it is profusely supplied with air-cells; and we refer our readers to the account already given (vol.i., p. 63,) of these peculiarities in its formation, merely adding, that from the facility of procuring specimens, a close examination of this species is recommended to those 
naturalists who wish to acquire more information on the internal economy of air-inflated birds.

In our account of the dismal tempests that so often prove fatal to the starving Cormorants, we might have added, that in the way of the Gannet they throw no impediment; buoyant as a bladder, no sea can overwhelm him; there he floats, if so it pleases him, lighter than a cork, on the summit of the most angry waves, without let or hinderance. On their airy, spreading pinions, too, they can, in case of disappointment in one place, transport themselves in an incredibly short time, to another. The inhabitants of St. Kilda assert, that they occasionally go a hundred miles or more for the purpose of fishing; a fact, they say, proved by finding in their nests hooks of English manufacture, sticking in fish-bones*.

Their nests are usually placed on the ledges of apparently inaccessible rocks, in which two eggs only are, for the most part, laid; but, breeding as they do, on so many of the desolate rocks of the northern shores, the number produced is incredible, and in many parts becomes a source of considerable profit to those who catch them. Thus, Mr. Landt, in his account of some islands near the Ferroes, says, "The old ones are caught in the middle of April, when they have built their nests, but before they have laid their eggs. The peasants steal upon them in the night-time, or when it is dark, in the places where they sit and sleep, and seize them by griping them in a peculiar manner, which prevents them from emitting any cry; for if they are suffered to make a noise, all the rest would awaken and take

* Martin's Kilda. 
themselves to flight. In the course of a season, those who are successful will catch, of old and young ones, about four hundred brace."

As we shall have occasion to speak of the Gannet again, in giving a general account of the modes of catching the various sea-birds that are found upon our shores, we shall, for the present, take our leave of it, as well as of the two last divisions of this Table, the Phaetons (see vol. i., p. 95, ) or TropicBirds, and Anhingas, or Darters, both comparatively

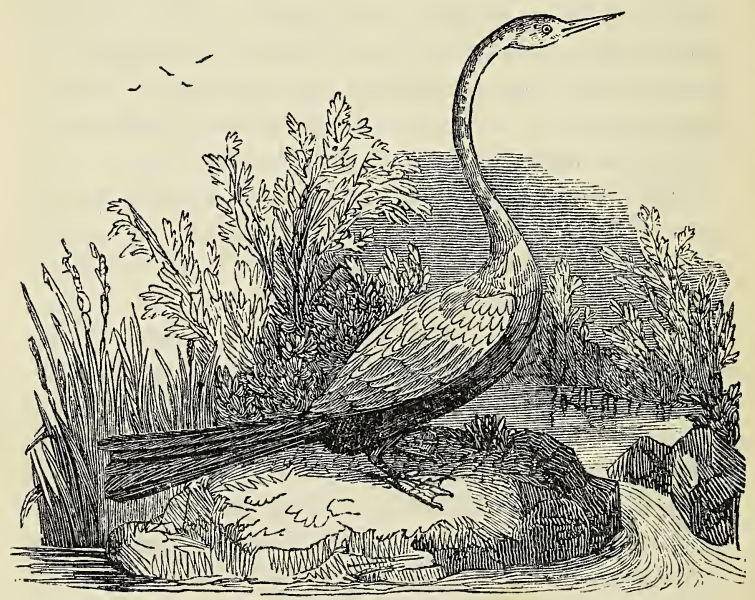

ANHINGA, OR DARTER.

little known, and inhabitants of remote regions: the former, from its name, being found almost invariably within the tropics, and generally at great distances 
from land; the Anhinga being confined to the savannahs, marshes, and rivers of the hottest parts of the African and American continents.

The long thin neck and beak, the slim body, and large webbed feet of the Anhinga, bespeak at once its real character as an excellent diver, which it certainly is,-for on the slightest appearance of danger, it will disappear in an instant, rising again at the distance of many hundred yards, and then only showing its narrow head just above the surface of the water. It is said, that when several are surprised perching, according to their practice, on a branch stretching over a river, they will all drop down together as if dead, and then dive away beyond pursuit. 


\section{CHAPTER X.}

LONGIPENNES; LONG-WINGED.-SKIMMERS-SINGULAR BILL. - TERNS, OR SEA-SWALLOWS-ANECDOTE OF.GULLS-CAPACITY FOR ENDURING COLD-VORACIOUS FEEDERS - BREEDING PLACES. - SOUTH STACK DESCRIBED.-ALBATROSS-ROAMING HABITS.-TRISTAN D'ACUNHA: RESORT FOR BREEDING-VORACITY. PETRELS-NESTS-FEED AT NIGHT-SUPERSTITION OF SAILORS RESPECTING.-BREVIPENNES; SHORTWINGED. - DIVERS. - CRESTED GREBE-GREAT DESTROYERS OF FISH.-GUILLEMOTS.-RAZOR-BILLS.PUFFINS AND AUKS.

Table XXIX. (See vol. i., p. 24.)

Order 6. Palmipedes. Tribe 3. Longipennes. (Long-winged).

This tribe comprises:-1. Rhynchops or Skimmers; 2. Sterna, Terns ; 3. Larus, Gulls ; 4. Diomedœa, Albatross ; 5. Procellaria, Petrels.

All these are long-winged birds, proper to the main ocean, and, by means of their powers of flight, are spread widely over the world. They may be known by either having no back-toe at all, or by that toe being free-that is, not united with the others by a membrane, forming one large web, as in the preceding tribe; and by their bill, without indentations, but bent at the end, as in the Procellaria or Petrels, the extremity of which seems to consist of a piece fastened on, or pointed, as in all the rest.

The Skimmer (Rhynchops) derives its name from 
the way in which it feeds, flying generally so close to the water, that the under mandible just skims below the surface, while the upper is kept wide open, so that on its meeting with any floating substance, it closes immediately upon it. It is a bird with little feet, long wings, and a forked tail; but its bill is so extraordinary that there is no mistaking it for the Sea-Swallow's, which in other respects "it closely resembles: the lower mandible is the shortest, and the other shuts upon it like the two blades of a pair of scissors.

Terns, or Sea-Swallows, have very long and very pointed wings, with forked tails and short feet, in which they resemble Swallows; but their mode of flight is very different; not having that darting rapid course, but a sort of graceful gliding motion,sometimes high in the air, then falling, as if they had lost their balance. Though perfectly web-footed, they never swim, but take their food, consisting of small fishes or insects, by descending to the water, and gently touching the surface with their beaks.

We have four species in this country, either residents, or occasional visiters. Those which breed here, generally lay three or four eggs, without any nest, preferring a low shingly shore, on which, we believe, the bird sits in the usual manner; but as it has been ascertained that an American species deposits her eggs in a similar situation, and leaves them to be hatched principally by the heat of the sun,the parent-bird only sitting upon them during the night,-it would be worth an observer's while to look after our Terns, and see how far they resemble their American connexions. 
They are very tame; and we have approached one of our British species (Sterna hirundo), as it rested on a patch of mud, a boat's-buoy, or a piece of floating wood, till we might have almost knocked it down with a stick. They appear, indeed, to have little or no sense of danger: if three or four are in company, and one is shot, the others will usually, instead of hurrying away, come fluttering down to the dead body, uttering their soft, mournful, or, as in this case it might be termed, reproachful cry. Their whole appearance is in truth so beautiful and attractive, that we can readily enter into the feeling with which one of these birds was regarded by a forlorn, starving boat's-crew, whose vessel, striking on an iceisland on her passage from Halifax, in North America, to England, foundered, and left her miserable inmates on the wide ocean, hourly expecting to be swallowed up by the heavy seas, which were constantly breaking over the crowded boats. It was on the evening of the sixth day after quitting the wreck*, just before night set in, that a beautiful white bird, "web-footed, and not unlike a Dove in size and plumage, hovered over the mast-head of the cutter; and, notwithstanding the pitching of the boat, frequently attempted to perch on it, and continued fluttering there till dark. Trifling as this circumstance may appear," continues the writer of the narrative, "it was considered by us all as a propitious omen. The impressive manner in which it left us, and returned to gladden us with its presence, awakened in us a superstition, to which sailors are at all times said to be prone. We

* Narrative of the loss of the Lady Hobart Packet. 
indulged ourselves, on this occasion, with the most consolatory assurances, that the same Hand which had provided this solace to our distresses, would extricate us from the dangers that surrounded us."

We come next to the numerous class of Gulls, a class which the sailor is sure to find wherever he goes, whether under the burning sun of the tropical regions, or the frozen icebergs of the Arctic circle, and always bearing the same restless, noisy character.

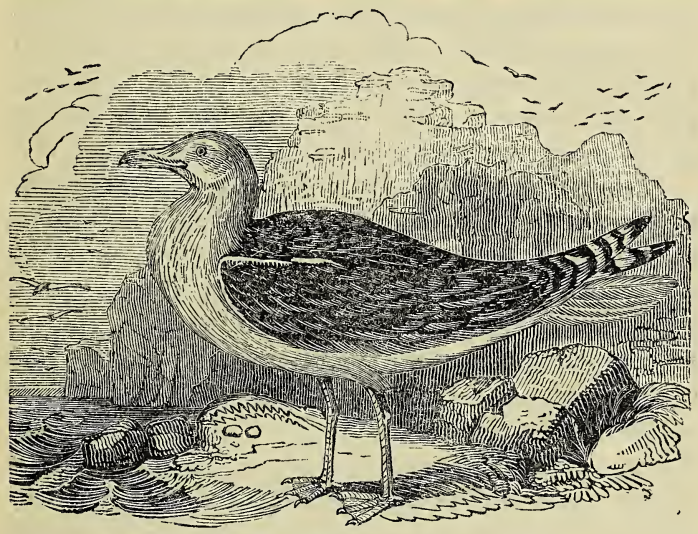

THE BLACK-BACKFD GUI.I.

They have been named, and justly so, the scavengers of the sea, for nothing comes amiss to their voracious appetite: loathsome as may be the putrefying carrion left on the beach, to the Gull it is just as acceptable as a meal on the finest and freshest fish. On either they will gorge almost to suffocation; and in that state may be taken up torpid and insensible. vol. Ir. 
Some years ago, in riding with a friend on the seashore, we espied a Gull lying motionless on the sand, apparently dead; but as its eyes were open, life was clearly not extinct. Suspecting it to be a wounded bird, we alighted to examine the extent and nature of the injuries it had received; but not a drop of blood was to be seen, neither was a feather ruffled. After having, therefore, handled it for several minutes, without its evincing the slightest symptoms of vitality, beyond the opening and shutting of its eyes, we threw it into the air, when, to our inconceivable surprise, the apparently dead bird expanded its wings, and, tucking up its legs, flew off with the utmost composure and steadiness.

Nature has amply provided them with means for their wandering lives. While the Cormorant is pent up in his cavern, and most of the other sea-birds are driven to their rocks and crags, during heavy gales, it matters as little to the Gull as to the Gannet, that the weather be fair or foul. Cold has no effect upon him, provided as he is with a thick coat of the softest down: light too as he is, he tops and rides over the waves without an effort; and his wide wings insure him a safe conveyance from every peril, save that of the gun, to which he may be exposed.

They are a very numerous tribe, differing a good deal in their habits, if not in their external features. The king of them all seems to be the Burgomaster (Larus glaucus), a name given by the Dutch, being the title of their chief magistrate, to which, by his conduct, he has a fair claim, for no other Gull dares dispute his authority when he 
chooses to exert it. A constant attendant on the whale-fisher, whenever they are busied in cutting up a whale, he hovers over the carcass, and having fixed his eye on a choice morsel of blubber or flesh, which some other of the Gull tribe has secured for itself, down he comes, and, forcing it to abandon the prize, carries it off as his own; or, if pressed by hunger, he will sometimes even fall upon one of the smaller sea-birds, and devour it whole. Thus, one of them was shot in the Polar expedition under Sir Edward Parry, which immediately disgorged an Auk, or Greenland Dove; and on opening him, another was found undigested in his stomach. But this Burgomaster, tyrant as he is, has a rival quite his equal in tyranny, and, though his inferior in size, surpassing him in courage and activity. The Arctic Gull, or Dung-Hunter (Lestris parasiticus), fears no bird, nor even hesitates to attack any animal, of whatever size, that comes too near its nest. Where they breed in considerable numbers, neither Hawks, nor even Eagles, are allowed to approach; for if, either by accident or design, any of these birds of prey are seen, the whole assembly attack, and compel them to retire. Hence, in some places where they abound, they become the guardians of the young lambs, which the people consider perfectly safe during summer; and, in return for this protection, the Gull is never molested, being held in no less esteem than the Stork in Holland, or the Ibis in Egypt. The unfortunate birds most exposed to the attacks of these robbers are their brethren, the Herring-Gulls, and Kittiwakes, probably because, being the most diligent pursuers of fish, they are 
sure to find from their exertions a never-failing supply.

Herrings form the chief provision for the immense flocks of these birds, which in the season are always found near the shoals. It has been remarked that they seem to have an instinctive knowledge of the habits of these fish, and act accordingly. In the Shetland Islands, at a particular time of tide, the herrings descend from the surface; and during the intervals of their absence, the Gulls, as if fishing was out of the question for the time, generally repair inland, and rest among the heaths. As soon, however, as the tide changes, and the herrings again rise, they quit their retreats, and by loud and discordant screams, seem to express to each other their joy at the approaching feast; when they take wing, it is a sure sign that the period for fishing is at hand. It is astonishing to see with what precision and regularity the flocks, far removed from the sea, rouse themselves from a state of quiet and repose, and suddenly, full of bustle and activity, betake themselves to the herringgrounds.

The Gulls hitherto mentioned are, more or less, strangers to this country, or may, at all events, be considered as mere casual frequenters of our coasts, preferring solitudes still more wild and lonely than our own. We have, however, several species which breed, and remain with us all the year. They build on several parts of our rocky shores; and few scenes present more attractions, to an observer of nature, than a view of one of these wild spots in that season. We shall describe one, that we have often visited, and 
give, at the same time, some particulars relative to the habits of the birds of which we are now speaking.

The spot we allude to, is at the back of a mountain near Holyhead, which terminates abruptly in a series of precipices. At the foot of one of these is a small island, called the South Stack, on which a lighthouse has been erected within the last few years, well known to those who navigate the Irish Channel. Upon this rock, which, before the erection of the light-house, was almost inaccessible, myriads of seafowl used to build; but when the works were commenced in 1808, the unusual appearance of persons on the island, with their noisy operation of blasting, so disturbed the proceedings of the birds recently arrived, that, with the exception of a solitary pair of Gulls, the whole body, including Guillemots and Razor-bills, took to flight, leaving the workmen in full possession of a spot which the birds, from time unknown, had occupied by a sort of prescriptive right. This solitary pair had taken post on an inaccessible ledge of bare rock, in the face of a precipice, and seemed to be aware, that nothing but shot or stones could dislodge them. Their determined confidence in the security of their stronghold met with its due reward, orders being issued that none should molest them. The consequence was, that in a short time they became quite familiarized to the noise and bustle, and remained until their young were reared, and in a condition to shift for themselves.

In the ensuing Spring, the same pair, as was supposed, retook possession of their old post-and strict orders, as before, were given, on no account to disturb them; and, as a further protection, no fire-arms 
were allowed to be used; nor were strangers who disregarded these rules to be admitted again on the island. In consequence of a rigid attention to these humane regulations, the same pair continued, for five successive years, to visit this ledge, rearing their young, consisting generally of two, and never exceeding three in number. But although only this single pair were observed to breed on the island, a considerable number, at times, as if aware of their security, sought the shelter denied them on the main-land; where, notwithstanding the bare and perpendicular character of the precipices, there was scarcely a spot among the clefts and hollows to which the young men and boys of the neighbourhood did not find their way, in search of eggs, for which they found a ready demand.

The main body of Gulls at length finding that these wonted haunts no longer afforded security, either taught by the experience of the above pair, or by their own observation, in the Spring of the sixth year took refuge on the island, chiefly at the south side, on an inclined plane of rock, where they have remained during the breedingseason ever since; and on this spot, in particular, their artless nests are spread in such numbers, that it is difficult at times to avoid treading upon them. It is remarkable, however, that only two pair of the Black-backed Gulls returned, and these, according to their usual habits, not only build apart, but never herd with the rest. Neither have the Razor-bills and Guillemots re-established themselves in the same abundance, or with the same apparent confidence,-which may, in some degree, be 
accounted for, by the parts of the rock most suited to their habits having been more or less used as landing-places. But although these poor birds have, contrary to the general rule, found a protector in man, they are not entirely without their troubles and annoyances. Certain Crows (the light-keepers say, a pair only of one particular species, probably the red-legged, Corvus graculus, ) come at the same time, and build their nest just opposite the Stack, as if for the express purpose of harassing and stealing their eggs. For no sooner do the Gulls begin to lay, than these two Crows are perpetually on the lookout, frequently hovering over, and watching for an opportunity to carry off a prize.

The moment the thieves appear, the whole Gull colony is in a state of commotion and consternation: those on the nests cowering over their new-laid treasures, while the others, by their screams and menacing attitudes, do their best to frighten and drive the marauders away. But the cunning Crows usually gain their point: watching an opportunity, down they pounce, pierce an egg with their sharp beak, and fly off with it in a trice.

A curious circumstance fell under the observation of the light-keeper. A pair of these Crows had, for some years, frequented the same spot, when, in one season, the female was shot, and the male almost immediately disappeared, remaining absent for the space of three or four days, when he returned with another partner, and the business of nidification was carried on as before.

The Gulls, at the breeding season, so numerous on the island and adjacent coast, disperse them- 
selves for the rest of the year; and are never seen congregated in great numbers, except when attracted by shoals of herrings, or some similar cause; but it is positively asserted by the lightkeepers, as a very extraordinary fact, that they all instinctively return to the South Stack during the same night, on or about the 10th of February; and retire, with the exception of those that, having been robbed on the main, had resorted to the island to renew the labours of incubation, about the night of the 12th of August. The keepers state that, in the middle of the former night, they are warned of their arrival by a great noise, as it were a mutual greeting and cheering; adding, that they look to their return as that of so many old acquaintances, after a long absence, announcing the Winter to be over, and Spring approaching. For a time they appear to congregate together without any order whatever; but in the course of a month begin to pair, and, getting their nests in readiness, proceed to lay their eggs. As if confident of protection, they become quite familiar; at least this is the case with the Larus canus, or common Gull.

In one part, a point of rock projects considerably; its extremity commanding a full view of the various ledges, as well as declivities, on which the Gulls have established themselves; and there have we sat, and could have remained for hours, watching these sea-birds, and listening to their wild cry, mingling with the hoarse roar of the waves lashing the rocks below. When resting there, some would fly so near, that the fanning of their wings could almost be felt, while others, would delight within a 
few yards, and conning us over with a vacant simple stare, kept repeating their plaintive, melancholy, imploring sort of note. While, on the other hand, a pair or two of the large Black-backed Gulls (Larus marinus) from time to time sailed by, and then dropping on their inaccessible ledge, reconnoitred us with a scrutinizing look, from their keen, suspicious, penetrating eye. The former, barely opening their comparatively slender beaks enough to give vent to a gentle cry, seemed to say, "We are poor harmless creatures; do not hurt us." The latter, on the other hand, the moment they had alighted, opening their's as wide as possible, uttered a loud hearty scream, as much as to say, "This is our territory ; you have no business here." Not far from the resting-place of this pair of Black-backed Gulls, a couple of the common sort had, when we last visited this interesting spot, established themselves on a bit of a plateau, that made one giddy to look at, and quite tremble for the fate of their sole offspring, a little grey downy-covered nestling, with about half an inch between its toes and destruction, for a breath might have blown it over: but there stood the little tottering bird, quite at its ease, so well tutored, apparently, that when the old ones successively returned with food, it betrayed none of those emotions common to young birds, which would certainly have thrown it off its balance; no tremulous movement of its flappers, no impatient stretchings of its neck, no gapings of its mouth. There it stood, motionless, as if conscious of the dangers attendant on even the slightest bustling display of satisfaction. It was impossible not to feel 
something like pity, for the dull life it was doomed to lead in such a cradle; it being evident that, from the moment of its quitting its egg-shell, to that hour, the choice of standing on its right or left leg, or a cautious putting forth of one foot before the other, to the extent of a few inches, was the only source of amusement or variety within its reach. It was curious to observe the proceedings of many of the older birds. The din was incessant, and some seemed quite exhausted with screaming, or hearing others scream; for they might be seen flying off from the main body to a retired crag or niche, as if to rest a while in perfect silence.

Now and then, indeed, as if by mutual consent, the uproar entirely ceased, and the whole body settled themselves on a rocky inclined plane, interspersed with grass, just below the light-keepers' dwellings, which formed their grand nursery establishment; for there, in every stage of growth, hundreds of young ones were moving about. No doubt each parent had a perfect knowledge of its own offspring, though, generally speaking, there were no signs of recognition; for, to all appearance, old and young seemed to mingle, without much reference to relationship; and a stranger might have supposed there was a common property in the nestlings. The only sign of parental attachment was, that an old bird would now and then fix its eye in a more pointed manner upon some one of these living grey puff-balls of downy feathers, and then, suddenly opening its mouth, deposit at the feet of the fledgling, a crawful of half-digested shrimps or softened crabs. 
We come next to the largest sea-bird that flies, the Wandering Albatross (Diomedea exulans), of which we have already partially spoken; but large as they are to the eye, they are not so in reality, for so abundantly covered are they with feathers, that, when plucked, they appear not above half their original size, and, when cleaned, their weight is comparatively trifling. With this light body, and an immense spread of wing, our surprise is lessened at their being able to venture so far from land; Captain King* having met with them almost a thousand miles from the nearest shore.

It is a pleasing relief to the eye, when sailing over the landless oceans frequented by the Albatross, and where, except now and then a passing sea-bird, nothing meets the sight but a tract of boundless water, to observe this superb bird sailing in the air, in graceful and elegant movements, seemingly under the influence of an invisible power; for, when once elevated in the air, there is scarcely any visible movement of its wide wings. Rising as if some concealed power guided its various motions, without any muscular exertion of its own, and then descending, it sweeps the air close to the stern of the vessel, with an independence of manner, as if it were monarch of all it surveyed.

It has been remarked by an observer, who has given the best account of these birdst, that they could lower themselves even to the water's edge, and then again rise without any apparent impulse. Whether with or against the wind, seems to be a

* King's Australia, vol. ii.

+ Bennet's Wanderings in New South Wales. 
matter of indifference to them. No tempest troubles the Albatross, for he may be seen, with equal vigour, sportively wheeling in the blast and carousing in the hurricane. Of this noble bird it may indeed be literally said,

His march is o'er the mountain wave,

His home is on the deep.

In the gale he will sweep, occasionally, the rising billows, and seem to delight in the spray bursting over him. Tired, in truth, they rarely are; but should they be, though never seen to swim, they can, in consequence of their feet being webbed and remarkably large, walk on the surface of the water, when it is smooth, with hardly any assistance from their wings; and the noise of their tread may be heard at a great distance*.

They are most voracious birds, and easily caught by baiting a hook with offal, and letting it trail after the vessel by a long line: on seizing and swallowing the bait, it will sometimes rise into the air, from whence, by hauling on the line, as a boy does a kite, it is brought on board. Sometimes, however, they break the line and escape, which has afforded a proof of the distance and length of time they will follow a vessel. Thus, when hauling in one of large size, the line slipped, and the bird, consequently, swallowed the hook, and a portion of the line, the remainder of which hung pendent from the beak. From being thus marked, it was ascertained that it followed the ship two days, and might have been doing so for days before; and in these forty-eight

* Weddell. 
hours, as she sailed at the rate of two hundred miles per day, from the irregular flight of the bird, the space it went over could not have been less than three or four times that distance. Their reason for preferring rough weather to smooth may easily be accounted for, the agitation of the waves no doubt bringing to the surface those marine animals which serve them for food; they will glide down on them with unerring aim and fearful force, transfixing whatever they have aimed at with their large, strong, and trenchant bill.

A poor fellow who fell overboard from a man-ofwar, off the island of St. Paul's, in the Southern Indian Ocean, was immediately perceived by two or three Albatrosses; the boat was lowered with all speed, but nothing was found excepting his hat, pierced through and through with the violent stroke of their beaks, the first of which had, most probably, penetrated the skull and caused instant death.

These birds are found round the whole circle of the globe in the Southern Seas, retiring to breed in the most desolate and dreary situations. Captain Weddell, who has penetrated further into these inhospitable southern regions than any other navigator, met with them, in great numbers, amidst the icy rocks of the New South Shetlands, associating, as we shall hereafter see, with the Penguins ; though, in the dreary island of Tristan d'Acunha, another traveller, Mr. Earle, describes them as the sole occupants, without any interloper, whether friend or enemy. In the higher regions, amidst the barren and cindery peaks of black rocks composing that dismal island, he found the young ones on the ground, 
completely uncovered, and the old ones stalking around them. Each bird lays but one egg, and, after the young one is hatched, it has to remain a year before it can fly.

Their style of courtship, and of selecting their mates, is described as very ludicrous. The couple approach one another with great apparent ceremony, bringing their beaks repeatedly together, swinging their heads, and contemplating each other with very deliberate attention. Sometimes this will continue for two hours together, like a courtship in a pantomime. They have great power in their beaks, and, when on the nest, they will defend themselves for half an hour against an active dog.

Their eggs are inferior to those of Geese, and they have less yolk, and more white, in proportion to their size, weighing generally about one pound and three quarters. All birds, of the Albatross and Gull kind, on these islands, lay their eggs in October; and, when new laid, they are a great source of refreshment. Voyagers mention another large bird, called the Nelly-bird, also a species of Albatross, (Diomedea spadicea,) of an unpleasing appearance, and extremely voracious. Their fondness for blübber often induces them to eat so much, that, like the gorged Gull we have described, they are unable to fly. A flock, of perhaps five or six hundred, have been known to devour twenty tons of sea elephant fat in six or eight hours ; that is, upwards of seventy pounds for each. The Albatross will, at one gulp, swallow a salmon of four or five pounds weight, but if more be taken, and the whole will not go into the stomach, the bird is often seen with the 
last hanging partly out of the mouth. We have noticed (vol.ii., p.215, the proportion of food consumed by a Cormorant, compared with the weight of its body, but its voracity is as nothing in comparison with that of the Nelly-bird, which appears, in the course of twenty-four hours, to dispose of nearly three times its own weight of food.

The last genus of this tribe is that of the Petrels, two only of which are well known to us, as frequenters of our shores: the Fulmar, which is nearly as large as a Gull, and the Stormy Petrel, better known to sailors by the name of Mother Carey's Chickens, about the size, and in appearance not unlike the Swift, or largest Swallow. Their whole bodies seem to be filled and impregnated with oil, to such a degree, that in some of the most remote islands of the Hebrides, the inhabitants actually form them into candles, by merely passing a rush through the body and out at the beak, which is found to burn as well as if dipped in tallow or any other grease. So full are they of this oil, that the Fulmar uses it as a weapon of defence, and, when taken, will squirt over the person who handles it, a strong jet of pure oily liquid. When shot, if it falls into the sea, a partial calm is created by the quantity ejected from its mouth.

With their quantity of down, which supplies the islanders with warm bedding, - and fat, which is considered an efficacious remedy for wounds; as is their oil, which is preserved in large bunches of long bladders, made of the gorge or stomach of the Solan Geese,-these birds become more valuable to the inhabitants than the poultry tribe to us. The poor 
people of St. Kilda, in a word, prize them so highly, that it is proverbial with them to say, "Deprive us of the Petrel and Fulmar, and St. Kilda is no more."

They build, like most other sea-birds, in holes and chinks of rocks, or on the ledges of precipices; though upon Norfolk island, in Australia, a species has been discovered which burrows in sand like rabbits, lying hid in the holes by day, and sallying forth in the evening in quest of food. Their reason for concealing themselves appears to be well founded; for no doubt this is the same species met with in the other remote islands of the Southern Indian Seas, spoken of * as living in perpetual dread of another of its own genus, the great Black Petrel (Procellaria equinoctialis); and well it may, for its sable enemies are incessantly looking out for its heart and liver, on which alone they feed, leaving the rest of the body untouched.

At night therefore only, they venture forth, but not with much safety, for then a new danger awaits them, in the shape of the seal-catchers, who attract them by torches, and kill them in multitudes, for the sake of their oil. They probably, however, prefer the darkness of night for other reasons ; for our common Stormy Petrels, whose hearts and livers are in no danger from enemies by day, are observed by the people employed in the cod-fisheries of the north, to come forth like the Bat at dusk, when they see them skimming over the water, catching a glimpse of them only by the. white spots on their rumps, and the side feathers of their tails. But, though apparently so wild and solitary, if caught and taken home, they will

* Macartney's Voyage, vol.i. 
become so tame as to suffer themselves, without the least fear, to be touched and handled. One kept in a cage for some time, was supported by means of smearing the feathers of the breast with train oil, which the bird afterwards sucked with its bill. When the oil was placed in a saucer in the cage, it would dip its feathers therein, and then suck the oil from them.

Sailors have a superstitious dislike to the Stormy Petrels, or, as they are commonly called, Mother Carey's Chickens, believing that their appearance forebodes storms, with which they are in some way or other connected. That storms do frequently occur when, or soon after, these birds are seen, is certainly true; but the cause probably is, that, instinctively feeling the approach of a gale, they are disquieted, and are anxiously awaiting its arrival, and, therefore, hover round the ship, which they imagine may shelter them from its fury: for, unlike the Albatross, or Gull, they seem to dislike the war of elements; and to this dislike may probably be attributed the otherwise unaccountable circumstance of their being so often found even many miles inland. The fact might be doubted, but for numberless recorded instances; for there is scarcely a county in England in which they have not been seen.

In 1832, upwards of twenty instances occurred, and many of them in the midst of crowded towns: thus, after a series of tempestuous weather, one was captured, which had been seen flying up and down the streets of a populous town, about seven or eight feet above the ground, apparently much exhausted; while others, after severe storms, were seen flying about the iron-furnaces at Low Moor, near

VOL. II. 
Bradford, in the West Riding of Yorkshire, probably attracted by the blaze of their immense fires.

They do not, however, always follow ships merely for shelter; we suspect that the scraps of food or grease, which occasionally fall over-board, frequently attract them. We have heard of one which accompanied a ship from the Channel to the very shores of America, picking up or examining every thing that fell over-board. It was observed to be more clamorous during the night than the day. It appeared, moreover, to those who watched it, to dive, and remain under water for half an hour or more; and we have heard this power of immersion attributed to it by others; but we are inclined, nevertheless, to doubt even its power of diving at all; its form, lightness, thick coating of feathers, all being against its remaining under water for any length of time; added to which, such a power would be unnecessary, its food being prepared for it on the surface of the waters, and not below.

\section{Table XXX. (See vol. i., p. 24.)}

Order 6. Palmipedes. Tribe 4. Brevipennes (Short winged).

The characteristic feature of this, the last tribe of the last order of birds, is the extreme shortness of the wing, which, in many of them, prevents their flying to any distance, and, in some, partakes more of a fin than a feathered wing. Their legs are, moreover, placed far behind; their plumage is close and glossy, so as to resist water; all which peculiarities fit 
them for a more exclusively water life. It is divided into four genera:-1. Grebes, or Divers; 2. Guillemots; 3. Auks, or Puffins; 4. Penguins.

The Grebes, which take precedence in this list of the short-winged tribe, are the only birds whose habits lead them to pass comparatively peaceful lives, on the less agitated surfaces of our inland lakes and meres; the others being all, more or less, sea-birds, whose dwelling-place, when on land, is on wild rocks, exposed to storm and tempest, of which they take no heed, defended as they are by a rich coat of glossy plumage, whose smooth and oily surface is impenetrable to water.

The Grebes, though classed amongst the palmated or web-footed families, nevertheless, in some species at least, differ from them in one respect,-having only partial webs; the toes being flattened and furnished with what is called lobes or membranes, like those of the Coot. They are unsocial solitary birds, seldom more than a pair being seen together; and withal, so shy, that it requires all the address and skill of a keen sportsman to get within shot; though the inexperienced may think it an easy matter so to do, when he sees one of them apparently dozing within a few yards of the rushy confines of a pool of water. But the Grebe is neither sleeping nor off his guard; as the gunner would know, were he near enough to watch the motions of the wary bird. He would then see its clear penetrating eye glancing in every direction, alive to the approach of friend or foe, and, if suspicious of danger, its body gradually sinking, until the upper part of it only remained visible, and its sharp lance-shaped head thrown back on its slender neck, 
prepared to plunge at a moment's notice. So rapid, indeed, are their movements, that, on seeing the flash of a gun, they can dive into security, below the water, before the shot can reach them, as the following account will show.

"As I was out shooting," writes an eye-witness, "I saw one of these birds swimming towards a point of land, where I could easily conceal myself: so I repaired thither for that purpose. He came onwards with a wild anxious gait, constantly turning his head from side to side, as if to be upon his guard, against an enemy. I had arrived at the place, and the bird was approaching. Now and then, as he came on, he stretched his long neck, for several seconds, under the water, looking for small fish ; and when he had nothing better to do, he turned his head round, in order to tickle his tail with his bill. Watching the moment when he was so engaged, I fired, at the distance of thirty yards. My gun went quick as lightning, but the Grebe went quicker, and scrambling over, out of sight, came up again in a few seconds, perfectly unhurt."

The skins of these birds, from their beautifully soft and silky texture, make valuable tippets for ladies; and form an article of trade from North America, and other countries where they abound. They are chiefly taken by the Indians, who contrive to kill them at great distances, using a large quantity of powder and very little shot; and they have also a way of enticing them by a particular call, and a red rag at the end of a stick-methods which they practise with great success.

One of the most common in our country, and, at 
the same time, one of the most beautiful, is the Crested Grebe (Colymbus cristatus), of whose head we have given a figure (see vol. i., p. 86). The bird has the power of moving the sort of shawl, or tippet, round its neck, as well as the two tufts or crests on its head, which, when erected, appear like two horns. This species, as well as some others, such as the Sea-Lark, already mentioned*, when alarmed, carries off its young under the wing. We once saw an old one, basking in the middle of a large sheet of water, with one or two young ones, apparently not long hatched, swimming round her. By the assistance of a telescope, the little downy divers might be seen, enjoying their new existence; at one moment darting along the surface, and then scrambling on the mother's back, who floated motionless, and continued to plume herself while the brood gambolled about her. One of the largest of this genus, the Great Northern Diver (Colymbus glacialis), may also be called a British bird, though but a rare visitant, preferring the more remote shores of the north, where it passes its existence as far as possible beyond the reach of men: not, however, that it can escape the snare of the hunter,-numbers being taken by the persevering efforts of those who know the value of their skins, which, when tanned and dressed, make excellent caps and jackets. But although the poor birds cannot avoid falling a prey to their pursuers, they contrive so effectually to seclude themselves from observation, during the breeding season, that, in the Orkneys, and other northern islands which they frequent, the inhabitants

* Vol. ii., p. 152. 
really believe that they make no nests at all, but, never leaving the sea, hatch their eggs under water, in a hole beneath the wing, prepared by nature for that purpose,-a belief, no doubt, encouraged by their being seen, like our Crested Grebes, taking their young upon their backs, or under their wings, for protection.

Rare as these birds are, they sometimes, either by choice or stress of weather, wander from their dreary northern abodes, and have been met with, very unexpectedly, not far from the habitations of men. For instance, a few years ago one was shot on Styperson Pool in Adlington, near Macclesfield: either from the close and glossy texture of its feathers, or its agility in diving, it was fired at nine times before it could be secured, and at length received its death-wound from a shot in the head. In the throat, which presented the appearance of a bag appended to the gullet, were found fourteen large perch, quite whole and fresh. Its voracity was such, that even after it was evidently wounded, it continued to bring up fish when diving, remaining at each immersion several minutes under water, and making its way beneath the surface from one end of the pool to the other. Another of these birds was observed for a considerable length of time on a large piece of water at Westwood-park, near Worcester. The situation of this lake was very retired, no boat was upon it, and scarcely any person allowed to approach. This rare visitant seemed to excite as much alarm amongst the other wild fowl on the lake, as surprise amongst those who had the opportunity of seeing it ; for, whenever the stranger approached, they has- 
tened out of the way, and at all times kept as far off as possible. No attempt was made to capture it, as the owner of the water would not allow it to be molested. Their extreme shyness and timidity, though on the whole contributing to their preservation, is, in some instances, the cause of their being taken. Thus, the Red-throated Diver, another species near akin to the above, when met with by the natives of the northern islands, flying, as they often do, from one of the small inland lakes to another, are so terrified by loud shouts, that they will frequently fall down; and if they drop on the grass or heather are easily caught by hand, as from the awkward position of their legs, which, though well suited for water, are by no means adapted for land, they can neither walk nor take wing again.

The Guillemots constitute a family of sea-birds in many respects resembling the Divers, but with wings still shorter: the chief distinction, however, is their having no hind-toe or thumb; they live on fish and crabs, and when on land frequent ledges of rocks, where they build their nests. The species best known to us is that called the Foolish Guillemot (Colymbus troile), a name probably acquired by its apparent stupidity, in not only allowing a very near approach, but even frequently remaining within shot, although its companions may have been killed close to it. These are the birds which so often attract the attention of passengers in steam-boats, by remaining quietly tossing on the waves, without seeming to notice the noise and splashing of the paddles; seldom, if ever, taking flight, but usually diving and rising again at short distances. The bird, however, 
by no means merits its character for stupidity, as those who have the most experienced fowlers find it a very difficult matter to catch them, except by means of snares laid near their nests.

Closely allied with these, and by many naturalists more or less associated with them, are the Alca tribes, comprising, amongst other birds, our Razorbills and Puffins, which, although not generally scattered over our shores, are found in prodigious numbers on certain favourite spots, which they have from time immemorial selected for themselves. One of the most frequented spots for the latter is Puffin Island, near Beaumaris; though further towards the north, they are still more widely spread, and may be found, during the breeding season, in still greater abundance. They are often called Sea-Parrots, from the peculiar form of a beak, capable of inflicting very severe wounds, and of which they make great use, sometimes to their own disadvantage, as the following singular mode of taking them, which does not seem confined to our own country, will fully prove.

"In Iceland," says Dr. Henderson, in his missionary travels to that island, "they are caught by means of a hook fastened to the end of a stick; and what is singular, when one is dragged out, his companions take hold of him, and endeavour to retain him; by which means they are often caught to the number of three or four at a time."

"In Norway," says Colonel Brooke, "Puffins breed in great numbers on the rocks; and the mode of catching them is precisely the same as that adopted in the northern parts of Great Britain, with the ex- 
ception, that a dog is trained to the sport. The Puffins sitting together in prodigious numbers in the deep holes and clefts of the highest rocks, one of these little dogs is sent in, which seizes the first by the wing. This, to prevent being carried away, lays hold with its strong beak of the bird next to it, which, in like manner, seizes its neighbour, and the dog continuing to draw them out, an extraordinary string of these birds falls into the hands of the fowler. They are in Norway taken for their feathers, which are valuable."

Sociable as they appear, and attentive to their young, there yet seems to be a curious exception occasionally occurring towards the close of the breeding season, when, on their departure, the broods of the latter hatches are left a prey for the Peregrine Falcon, who watches at the mouth of the holes, and seizes the poor starving nestlings, when compelled through hunger to quit their inner chambers, thus escaping the lingering pains of famine by a more violent and immediate death.

With respect to the Razor-bills and Guillemots, we shall again refer our readers to the same rockscenery of the South Stack, already noticed in our observations on Gulls, where, as on a stage of Nature's theatre, we have often watched their motions from the verge of a projecting little promontory, or arm of rock, immediately facing a precipice beyond the reach of human intrusion, intersected by innumerable fissures, crevices, ledges, and shelves, admirably adapted for tenants requiring such accommodations, and where, accordingly, an army of Razorbills and Guillemots have taken up their position, 
almost, though not entirely, to the exclusion of the Gulls; and therein, as if conscious of their safety, (it being an inviolable rule never to disturb them,) they carry on their usual occupations with the most perfect unconcern, permitting an observer to enter fully into their domestic arrangements.

At our last visit, closely jammed, in a lateral niche just opposite, sat seventy-two Guillemots, all bowing their heads at each other, with a gravity and solemnity quite unaccountable. On they went for above a quarter of an hour, without intermission; each nodding slowly to its neighbour, who, with equal composure nodded as slowly in return. Now and then, on another ledge, one or two would come in from a short excursion, and jostling the whole line, send a dozen or two backwards over the dizzy height, croaking disapprobation at the intruders, who took the vacant places, utterly disregarding the confusion they had caused. It was impossible, at first sight, to divest oneself of an involuntary shudder, as they tumbled backward, headlong, into the abyss, where the sea was roaring and lashing the rocks below them, their squat plump bodies supported only by such comparatively disproportioned wings. One felt at every moment a sort of rising exclamation, "Ah, poor bird, nothing can save it; it must be killed!"-when, flapping its little pinions, away it went, cleaving the air, making its circuit of a mile or so, skimming now and then over the sea, but never touching the waves, and then rejoining its friends on the ledge, and in its turn jostling the line, and causing a similar ejectment of half a dozen others. In these solitary flights, however, they now 
and then meet with unpleasant adventures, as certain Hawks inhabiting the mainland occasionally make a dash at them. One day, the light-keepers were witnesses of one of these curious rencontres.

The Hawk was seen in full chase of a Razor-bill, but aware, probably, of the toughness of its skin, instead of assaulting his prey with the usual death pounce from the beak, he seized the unfortunate bird by the head with both his claws, and made towards the land, his prisoner croaking, screaming, and struggling lustily; and, being a heavy bird, so far incommoded or over-balanced its aggressor, that both descended fast towards the sea; when, just as they touched the water, the Hawk let go his hold, and ascended,-the Razor-bill as instantaneously diving below.

Amidst the myriads of old ones, we looked in vain for anything like a corresponding number of young, but scarcely a single individual was to be seen. It is true, that the females produce only one egg; but still that could not account for the small number visible: we could only, therefore, suspect, from certain friendly croakings uttered by the old ones, when turning their heads towards little chinks, the extremities of which were invisible, that the infant birds were kept in the back ground; and well they were so, for otherwise, in the constant disturbances, and tumblings, incessantly taking place, the whole rising generation must inevitably have broken their necks in the confusion, by falling over, before they were able to fly. But a greater surprise was excited, by perceiving, in the midst of the bustle, a solitary egg here and there lying on the bare rock, 
within a few inches of the edge. By what care or instinct was it preserved from falling? It has been said that, if they are removed by a human hand, it is impossible, or at least extremely difficult, to replace them in their former situation; whence it has been inferred, that they are glued by some secret cement to the rock. Some of our ablest naturalists, however, doubt this; but if it is not so, the mystery is rather increased than lessened-for they are in a most hazardous position; but they are preserved, though by what means we have yet to learn.

The Razor-bills were by no means so numerous as the Guillemots, and, generally speaking, did not mix with them; seeming to hold themselves apart, as the better bird of the two, peering at one another, and pluming their coats with a sort of dandy satisfaction at their superior brilliancy and glossiness.

Besides these more common species, there are others, rarely found in Britain, being chiefly confined to the colder and more inhospitable regions of the northern or southern divisions of the globe, where they exist in numbers almost surpassing our powers of computation. One species, in particular, the little Auk, or Greenland Dove (Alca alle), Sir Edward Parry met with by millions, when the ships got amongst the ice in particular spots, and they were killed for sea provisions. But in the southern hemispheres they appear to be even still more abundant. Adjacent to the islands of Australia*, the Sooty Petrels (Procellaria pacifica,) congregate in incredible masses, of from fifty to eighty yards in depth,

* Flinder's A ustralia. 
and of three hundred yards or more in breadth, not scattered, but flying as compactly, and as close, as the free movement of their wings will allow, and passing, for a full hour or more, with a swiftness little inferior to that of a pigeon. On these data, it has been calculated that the number in such a flight would amount to one hundred and fifty-one million, five hundred thousand birds! about one-fifth of the, whole population of the globe. These birds live and breed in burrows, and the number of burrows required to lodge such a flock would not be far short of seventy-six millions; and allowing a square yard for each burrow, the space covered would be something more than twenty-four and a half square miles, or nearly fifteen thousand six hundred and eighty acres of ground!

And though in such cheerless solitudes, man would soon perish for want of sustenance, living food seems to be placed there by Providence to a greater extent than in any other known parts of the habitable globe. Countless as are the myriads of these birds, still more countless, by millions and millions of figures, are the lesser marine beings on which they feed. Some idea may be formed of their abundance, by calculating the length of time that would be requisite for a certain number of persons to count the quantity contained in one square mile of sea-water. Allowing that one person could count a million in seven days, which is barely possible, it has been calculated that no less than eighty thousand persons should have started at the creation of the world, nearly six thousand years ago, to complete the calculation to the present time! And, if passing 
beyond the consideration of the actual numbers, we reflect that each of these minute beings has not only life, but a body wonderfully made, with instincts and senses peculiar to each,-how infinitely beyond the power of our imagination to conceive, is that great and overruling Power, who hath measured the waters in the hollow of his hand, and meted out the heavens with a span. 


\section{CHAPTER XI.}

PENGUINS - FIN-WINGED. - KING PENGUIN OF THE SOUTHERN REGIONS DESCRIBED-BREEDING PI.ACES -VALUABLE FOR OIL.-SEAFOWLER'S PERILOUS OCCUPATION-DESCRIPTION OF, IN SHETLAND, ST. KILDA, ETC.-SINGULAR ESCAPES-FATAL ACCIDENTS.

Hitherto we have considered birds as more or less inhabitants of the air, gifted with wings for that purpose: it remains for us to speak of two families, possessing indeed wings, but too small to assist them in flight, and used, therefore, only as fish use their fins, for giving them additional powers on, or beneath, the surface of the water, where they pass the greater part of their existence. They are the Penguins, properly so called, and the Aptenodytes, a word compounded from the Greek, signifying wingless divers; for although the wings of the former scarcely deserve the name, they are nevertheless covered to a certain degree with feathers, whereas those of the latter are only furnished with vestiges of feathers, at first sight much resembling fish-scales.

The Penguins are chiefly confined to the coldest regions of the northern or southern hemispheres. The rapidity with which these birds fly, if it may be so termed, under water, after fish, is quite astonishing. One which was caught in the Orkney islands, at first refused all food, and became so weak, that it was expected to die: at length, however, it was tempted to eat, and being plentifully supplied with fish, soon resumed its strength and activity. 
With a cord tied round its leg, to prevent its escape, it was permitted to sport in the water; but even with this restraint, which must have very much impeded its motions, it performed the motions of diving and swimming with a speed that set all pursuit from a boat at defiance, affording the most convincing proof that, had it been at full liberty, no fish could have escaped.

The Aptenodytes, which may be called southern Penguins, as they never come beyond the limits of the Southern Ocean, are very numerous on the lonely isles scattered over the dreary wilderness of those seas. The largest of these, the King Penguin, exceeds a Groose in size. As their legs project from their bodies in the same direction with their tails, they walk upright; and when a flock of them are seen moving in file, or arranged along the ledges of the rocks, they appear like a company of soldiers; for they hold their heads very high, with stretched necks, while their little flappers project like two arms. As the feathers on their breasts are beautifully white, with a line of black running across the crop, they have been by others compared to a row of children, with white aprons tied round their waists with black strings.

The great Albatross, as we have seen, spends the chief part of his life on the wing; the King Penguin, on the other hand, rarely quits the water, with the exception of the breeding season, when, in some places, though not always, as we shall see in our account of the Albatross, in Tristan d'Acunha, both unite in vast flocks, and people the rugged rocks for a time. When a sufficient 


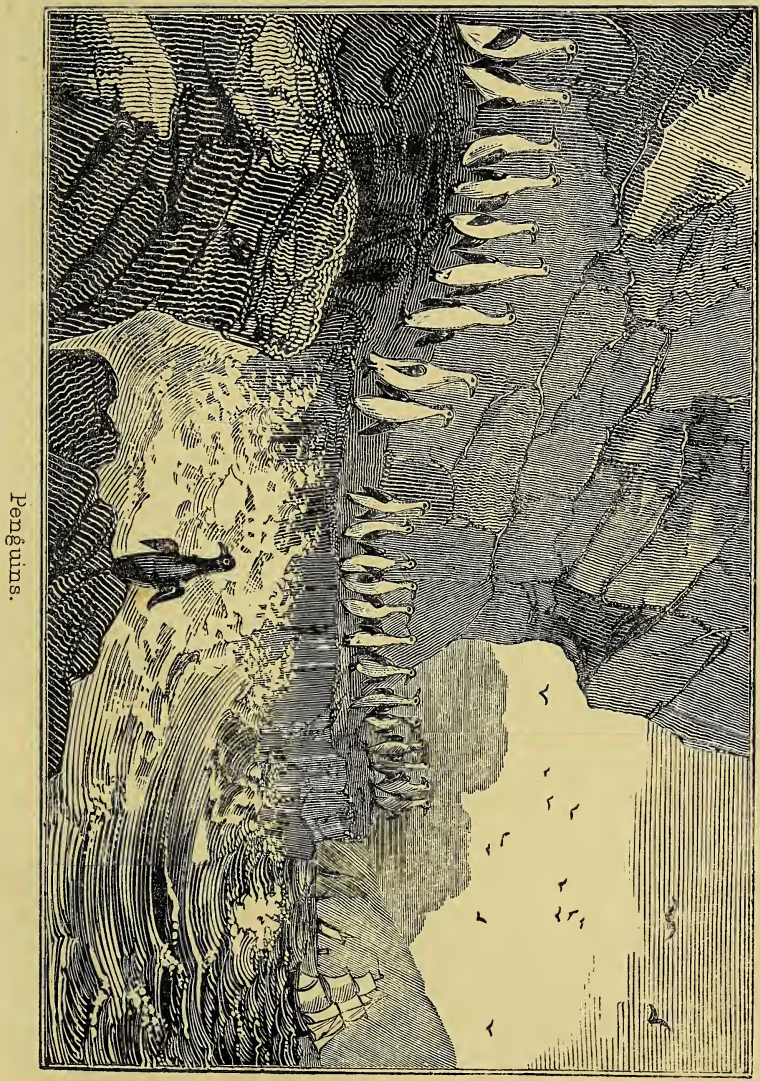



number of these birds are assembled on the shore, they appear, like the Herons, Storks, and some other species, we have mentioned in the preceding pages, to pass a day or two in deliberation ; on concluding the consultation, they proceed to the execution of the grand purpose for which they are then and there assembled. In the first place, they select* as level a piece of ground as they can find, often comprising four or five acres, and as near the water as possible,-always preferring that which is least encumbered with stones, and other hard substances, which might endanger their eggs. As soon as they are satisfied on this point, they proceed to lay out the plan of their intended encampment; which task they commence by tracing a well-defined oblong, large enough to accommodate the whole united parties. One side of this square runs parallel with the water's edge, and is always left open for coming in and going out; the other three sides are differently arranged.

The next step is to clear all the ground within the space from obstruction of every kind, picking up the stones in their bills, and carefully conveying them outside the lines, until they sometimes raise quite a little wall on three sides of their space. Within the range of stones and rubbish they form a pathway, six or seven feet in width, quite smooth. On this path they all walk by day, and on it the sentinels patrol by night. Having thus finished what may be called their outworks, they next lay out the whole area in little squares of equal size, formed by narrower paths, which cross each other at right angles, and which are also made very smooth. At each

\section{* See Morrit's Voyages.}

VOL. II. 
intersection of these paths, an Albatross constructs her nest, while in the centre of each little square is a Penguin's nest.

In this regular manner is the whole space taken up by Penguins and Albatrosses, with the addition of a few other sea-birds, which find places in unoccupied spots. But although these Penguins and Albatrosses are on such intimate terms, and appear to go on so well together, they not only form very different nests, but the Penguin, when she can, will rob her neighbour's. She merely makes a slight hollow in the earth, just deep enough to prevent her single egg rolling out; whereas the Albatross throws up a little mound of earth, grass, and shells, eight or ten inches high, about the size of a small water-bucket, on the top of which she sits. None of their nests are ever left unoccupied for a single moment, until the eggs are hatched, and the young ones old enough to take care of themselves. The male goes to sea till he has satisfied his hunger, and then returning, takes the place of his mate, when she flies off for the same purpose; the egg being conveyed to him by the hen placing her toes * together, and rolling it towards the male, the beak being used to place it properly.

During this season, the Penguins may be seen marching round, or up and down the pathways of this marine rookery, as it may be termed, while the air is darkened by thousands of Albatrosses, hovering like a cloud,--some continually alighting and meeting their companions, while others are as constantly rising and shaping their course towards the sea.

* Weddell's Voyage to the South Pole. 
Many of the birds of the two latter tribes, either from their feathers, skins, oil, or eggs, are considered, as it were, the standard harvest of the poor people, who, like them, are destined to abide amidst the wild and lonely islands of the ocean: it is, therefore, natural to suppose that no means are neglected, no ingenuity left untried in providing, whether for rent, clothing, food, or the lamp-light of their long and dreary Winter's nights, by laying in a store of each of these important articles, for which they are indebted to their companions, the sea-birds. And as the risks and difficulties which they encounter and overcome, form leading features in their lives, we shall close our account with a few of the hazardous and interesting details connected with the reaping of this their fearful harvest.

It is chiefly on the most rugged shores of Scotland, or on the more rugged rocks of the several adjacent islands, or still further to the north, in the Shetland or Ferroe Islands, that this " dreadful trade" is carried on in the perfection of its horrors; though in some parts of Wales, as, for instance, near the South Stack above-mentioned, and the Needle Rocks in the Isle of Wight, adventurous climbers will occasionally exhibit feats of perilous achievement, quite sufficient to satisfy most beholders. In some parts of the coast, immense mounds or fragments of rocks have been cut off from the main land by terrible convulsions of nature, or the incessant wearing of waves through fissures and narrow channels for successive ages. On a few of these spots, sea-birds, for a time, rested securely, till some bold adventurers 
devised the means of invading their territories, crossing the space by means of cradles, suspended on ropes thrown across.

At Carrick-a-Reade, near the Giant's Causeway in Ireland, and in the Shetland Islands, two of these airy conveyances are still in use, and, until a suspension-bridge was erected a few years ago, a third, and tolerably commodious and safe one, existed, connecting the South Stack rock with Holyhead mountain, in lieu of an original and far more primitive machine, which was, for a time, of necessity resorted to by those who wished to inspect the works on the island. It consisted of a small box, suspended on two strong ropes swung across a chasm of about an hundred and fifty feet, commencing its journey from a projecting point, about half way down the precipice of the main land, from which the passenger was vaulted over the gulf, by a rope leading to the island: a journey which, together with the scrambling down the unprotected face of the precipice, was sufficiently disagreeable and alarming, to convey a correct idea of the far more terrific communications adopted in less frequented places; such as that in Shetland, between the headland of Bressa, a sort of column rising out of the sea to the height of three or four hundred feet above its level, and not more than four yards in diameter on its summit. It is said that this cradle, by which the inhabitants pass easily and readily, and, from habit, without any fear of danger, was erected by a bold man in the neighbourhood, who mounted the hitherto supposed inaccessible sides of the rock. A great number of people were assembled, expecting to see him lose his footing, and 
fall headlong: however, he succeeded, and when at the top, waved his hat and cheered his friends; and then having, with their assistance on the opposite side, arranged the ropes and cradle, might have been the first to cross safely and successfully over his own bridge,-but being fool-hardy, and determined to descend by the way he had got up, before he had accomplished a third of the distance, his foot slipped, and he was dashed to pieces.

But though here and there, accommodations like this, or others, for facilitating the visits of the birdcatchers to their particular haunts, may be at hand, by far the greater number are taken by enterprising individuals, who have only their own steadiness of head, strength of muscle, and dauntless spirit, to insure success. We will describe the means and proceedings of those in St. Kilda, a small speck of of an island, the most westward and distant, (save a still smaller needle-pointed uninhabited spot, called Rockall,) in the midst of the Atlantic Ocean, containing a few people, who, from infancy accustomed to precipices, drop from crag to crag, as fearlessly as the birds themselves. Their great dependence is upon ropes of two sorts; one made of hides,-the other of hair of cows' tails, all of the same thickness. The former are the most ancient, and still continue in the greatest esteem, as being stronger, and less liable to wear away, or be cut by rubbing against the sharp edges of rocks. These ropes are of various lengths, from ninety to a hundred and twenty, and nearly two hundred feet in length, and about three inches in circumference. Those of hide are made of cows' and sheep's hides mixed together. The hide of 
the sheep, after being cut into narrow slips, is plated over with a broader slip of cow's hide. Two of these are then twisted together; so that the rope, when untwisted, is found to consist of two parts, and each of these contains a length of sheep-skin, covered with cow's hide. For the best, they will ask about thirteen pence a fathom, at which price they sell them to each other.

So valuable are these ropes, that one of them forms the marriage portion of a St. Kilda girl ; and, to this secluded people, to whom monied wealth is little known, an article on which, often life itself, and all its comforts, more or less depends, is far beyond gold and jewels.

The favourite resort for sea-fowl, particularly the oily Fulmars, is a tremendous precipice, about thirteen hundred feet high, formed by the abrupt termination of Conachan, the most elevated hill in the island, and supposed to be the loftiest precipitous face of rock in Britain.

And dizzy 'tis, to cast one's eyes so low!

The Crows and Choughs, that wing the midway air,

Show scarce so gross as beetles; half way down

Hangs one that gathers samphire; dreadful trade!

Methinks he seems no bigger than his head:

The fishermen that walk upon the beach

Appear like mice; and yon tall anchoring bark,

Diminished to her cock; her cock, a buoy,

Almost too small for sight: the murmuring surge,

That on the unnumbered idle pebbles chafes,

Cannot be heard so high. I'll look no more;

Lest my brain turn, and the deficient sight

Topple down headlong. 
Such is the beautiful description of Dover Cliff, by Shakspeare; but what would he have said, could he have looked down from this precipice in St. Kilda, which is nearly three times higher, and so tremendous, that one who was accustomed to regard such sights with indifference, dared not venture to the edge of it alone? But, held by two of the islanders, he looked over into what might be termed a world of rolling mists and contending clouds. As these occasionally broke and dispersed, the ocean was disclosed below, but at so great a depth, that even the roaring of its surf, dashing with fury against the rocks, and rushing, with a noise like thunder, into the caverns it had formed, was unheard at this stupendous height. The brink was wet and slippery, - the rocks perpendicular from their summit to their base; and yet, upon this treacherous surface, the St. Kilda people approached, and sat upon the extremest verge; the youngest of them even creeping down a little way from the top, after eggs or birds, building in the higher range, which they take in great numbers, by means of a slender pole like a fishing-rod, at the end of which was fixed a noose of cow-hair, stiffened at one end with the feather of a Solan Goose.

But these pranks of the young are nothing when compared to the fearful feats of the older and more experienced practitioners. Several ropes of hide and hair are first tied together to increase the depth of his descent. One extremity of these ropes, so connected, is of hide, and the end is fastened, like a girdle, round his waist. The other extremity is then let down the precipice, to a considerable depth, 
by the adventurer himself, standing at the edge: when, giving the middle of the rope to a single man, he descends, always holding by one part of the rope, as he lets himself down by the other, and supported from falling only by the man above, who has no part of the rope fastened to him, but holds it merely in his hands, and sometimes supports his comrade by one hand alone, looking at the same time over the precipice, without any stay for his feet, and conversing with the other, as he descends to a depth of nearly four hundred feet. A bird-catcher, on finding himself amongst the Fulmar's nests, took four, and with two in each hand, contrived, nevertheless, to hold the rope as he ascended; and, striking his foot against the rock, threw himself out from the face of the precipice, and returning with a bound, would again fly out, capering and shouting, and playing all sorts of tricks. Frightful as such a display must be to those unaccustomed to it, accidents are extremely rare; and the St. Kildians seem to think the possibility of a fatal termination to these exploits almost out of the question.

It is, indeed, astonishing to what a degree habit and practice, with steady nerves, may remove danger. From the island of the South Stack above mentioned, boys may be seen frequently scrambling by themselves, or held on by an urchin or two of their own age, letting themselves down the picturesque precipice opposite the island, by a piece of rope so slender, and apparently rotten, that the wonder is why it does not snap at the first strain. Yet, without a particle of fear, heedless of consequences, they will swing themselves to a ledge barely wide enough to 
admit the foot of a goat, and thence pick their way with or without the rope, to pillage the nest of a Gull, which, if aware of its own powers, might flap them headlong to the bottom.

Here too, as in St. Kilda, accidents are said to be of rare occurrence, though, of course, they do occasionally happen; but escapes, sufficiently appalling to make the blood run cold to hear of, are common enough.

The first we shall mention happened about two miles from the South Stack, on the rocky coast of Rhoscolin. A lady, living near the spot, sent a boy in search of samphire, with a trusty servant to hold the rope at the top. While the boy was' dangling midway between sky and water, the servant, who was unused to his situation, whether owing to a sudden dizziness from looking downward on the boy's motions, or misgivings as to his own powers of holding him up, felt a cold, sickly shivering, creep over him, accompanied with a certainty that he was about to faint; the inevitable consequence of which, he had sense enough left to know, would be the certain death of the boy, and, in all probability, of himself, as in the act of fainting, it was most likely he would fall forward, and follow the rope and boy down the precipice. In this dilemma, he uttered a loud despairing scream, which was fortunately heard by a woman working in an adjoining field, who, running up, was just in time to catch the rope, as the fainting man fell senseless at her feet.

We shall add two more, equally hazardous, and one fatal. Many bird-catchers go on these expe- 
ditions without any companion to hold the rope or assist them. It was on such a solitary excursion, that a man, having fastened his rope to a stake on the top, let himself down far below; and, in his ardour for collecting birds and eggs, followed the course of a ledge, beneath a mass of overhanging rock: unfortunately he had omitted to take the usual precaution of tying the rope round his body, but held it carelessly in his hand; when, in a luckless moment, as he was busily engaged in pillaging a nest, it slipped from his grasp, and, after swinging backwards and forwards three or four times, without coming within reach, at last became stationary over the ledge of the projecting rock, leaving the birdcatcher apparently without a chance of escape,-for to ascend the precipice without a rope was impossible, and none were near to hear his cries, or afford him help. What was to be done? Death stared him in the face. After a few minutes' pause, he made up his mind. By a desperate leap he might regain the rope, but if he failed, and, at the distance at which it hung, the chances were against him, his fate was certain, amidst the pointed crags ready to receive him, over which the waves were dashing far, far, below. Collecting, therefore, all his strength, with outstretched arms, he sprang from the rock, and lived to tell the tale,-for the rope was caught!

The next occurred at St. Kilda; where, amongst other modes of catching the sea-fowl, that of setting gins or nooses is adopted. They are fixed in various places frequented by the birds. In one of these, set upon a ledge, a hundred and twenty feet above the sea, a bird-catcher entangled his foot, and not being 



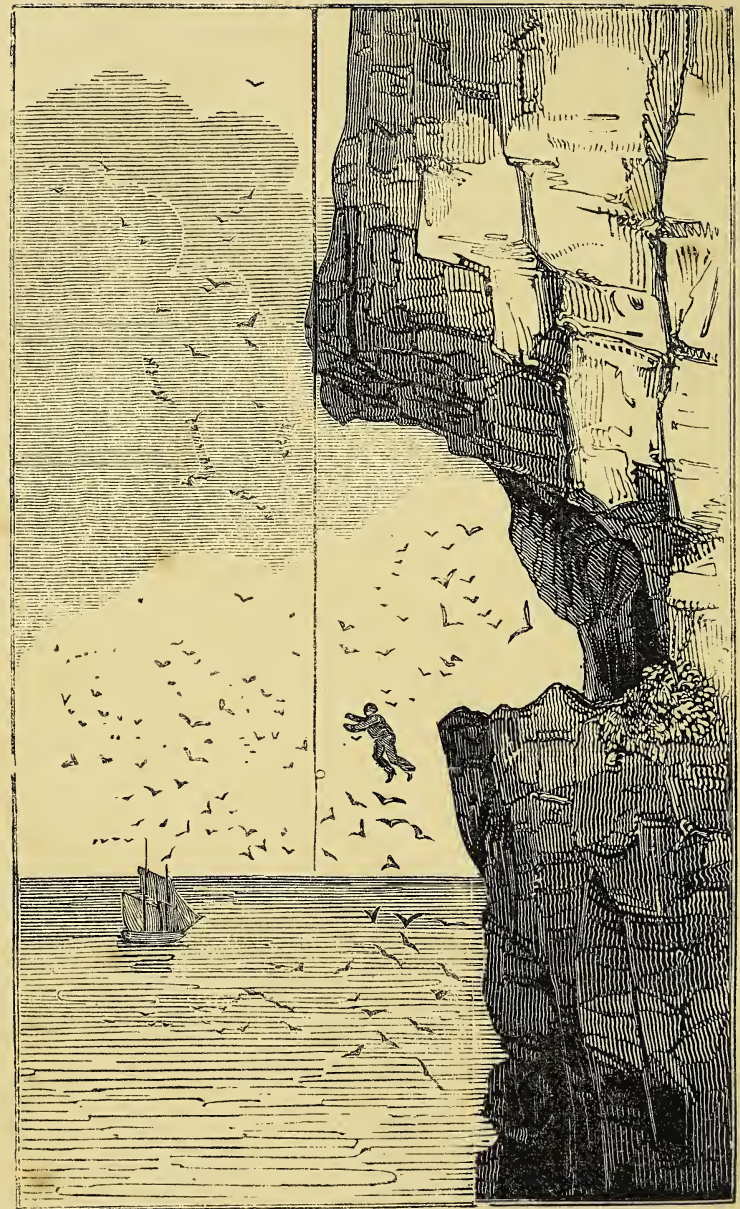

Perilous Leap of a Bird-Catcher. 
at the moment aware of it, was, on moving onwards, tripped up, and"precipitated over the rock, where he hung suspended. He, too, as in the preceding case, had no companion; and, to add to his misfortune, darkness was at hand, leaving little prospect of his being discovered before morning. In vain he exerted himself to bend upwards, so as to reach the noose or grapple the rock. After a few fruitless efforts, his strength was exhausted, and in this dreadful situation, expecting, moreover, that the noose might give way every instant, did he pass a long night. At early dawn, by good fortune, his shouts were heard by a neighbour, who rescued him from his perilous suspension*.

The last we shall relate, terminated in a more awful manner. A father and two sons were out together, and, having firmly attached their rope at the summit of a precipice, descended, on their usual occupation. Having collected as many birds and eggs as they could carry, they were all three ascending by the rope,- - the eldest of the sons first,- - his brother, a fathom or two below him; and the father following last. They had made considerable progress, when the elder son looking upwards, perceived the strands of the rope grinding against a sharp edge of rock, and gradually giving way. He immediately reported the alarming fact. "Will it hold together till we can gain the summit?" asked the father. "It will not hold another minute," was the reply; "our triple weight is loosening it rapidly!" "Will it hold one?" said the father. "It is as much as it can do," replied the son,-"even that is but

* Buchanan's Hebrides. 
doubtful." "There is then a chance, at least, of one of us being saved; draw your knife, and cut away below!" was the cool and intrepid order of the parent ;-" Exert yourself,-you may yet escape, and live to comfort your mother!" There was no time for discussion or further hesitation. The son looked up once more, but the edge of rock was cutting its way, and the rope had nearly severed. The knife was drawn,- the rope was divided,-and his father and brother were launched into eternity! 


\section{N D E X.}

Affectionate disposition of the Ostrich; ii. 113.

Stork and Crane; ii. 137.

Age of Goldfinches; ii. 14.

Air Cells in birds, use of ; i. 41, 63, 66 .

Albatross lives almost always on the wing; i. 95.

wandering, habits of the; ii. 235.

American, South, Goat-Sucker described; ii. 65.

Anastomus or open-beak; ii. 144.

Anis; ii. 75.

Annual return of birds to the South Stack; ii. 232.

Assemblage of Crows and other birds; i. 234.

Anhinga or Darter; ii. 220.

Avoset, beak of the; ii. 150.

Barn-Owl, habits of the; i. 179; i. 183.

Bell-Bird; i. 71.

Benefits derived from Rooks; i. 242.

and Injuries by small birds; ii. 25.

Bird-catchers employ Owls; i. 186.

Birds, their situation in the natural division of the animal kingdom; i. 6.

Bittern, light in breast of; ii. 133.

Blackbird crowing like a Cock; i. 69.

Bones of birds; i. 40.

Box, feeding, for Pheasants; ii. 98.

Breathing; i. 62.

Breast-bone; i. 44.

light in that of an American Bittern; ii. 133.

Breeding-Pheasant with poultry; ii. 95.

Bullfinches how taught to pipe; ii. 16.

Burrowing Owl described; i. 187.

Bustards taken by Hawks; i. 145. courage of the; ii. $94,111$.

Butcher-Bird, habits of the; i. 189. 
Canaries, history of, and trade in; ii. 15.

Cancroma, or Boat-bill; ii. 144.

Caprimulgus, Goat-Sucker; ii. 62.

Carrier-Pigeon, its rapid flight, and how used; i. 91 ; ii. 88.

Cassowary; ii. 116.

Catching Wood-Pigeons, mode of ; ii. 89.

Cat and Pigeon, anecdote of; ii. 92.

Caverns filled with Swallows' eatable nests; ii. 56.

Certhia, or Tree-Creeper; ii. 68.

Chavana Fidelis, capacity for filling itself with air; i. 65.

Children, instances of, carried off by Eagles; i. 116.

Chough, or red-legged Crow; i. 247.

Cinereous Crow, depredations of the; i. 249.

Classification, Tables of; i. 8.

Claw of the Goat-Sucker, why toothed; ii. 64 .

- serrated, of the Heron; ii. 131.

Cock, barn-door, courage of; ii. 92.

Condor, contest with a man; i. 138.

Constancy of Magpies and other birds; ii. 139.

Consumption of food by small birds; ii. 26.

Coots, nest of ; ii. 124.

Cormorant, habits of; ii. 215.

- weight of; ii. 215.

where differing from a Frigate-Bird; ii. 218.

Corn-Crake; ii. 129.

found dormant; ii. 43.

Cotinga ; i. 210.

Courage of Swallows; ii. 52.

Cranes; ii. 131.

anecdote of a lame; ii. 148.

Crocodile, birds feed in mouth of; ii. 155.

Cross-Bill, beak described; i. 32.

peculiarities of the; i. 54 .

Crows; i. 231.

- harassing the Gulls at the South Stack; ii. 232.

Cuckoos; ii. 74. 
Cuckos reu ny a Thrush; i. 207.

Cultrirostral, cutting-billed birds; ii. 131.

Cuneirostral, wedge-billed birds; ii. 74.

Dangerous instinct of Herons and Bitterns in darting at the eye; ii. 143.

Dardanelles, incessant flight of a species of Petrel, on the; i. 98.

Dates of the arrival and departure of certain birds; i. 111.

Desertion of young, instances of; i. 221.

Desperate leap of a Bird-catcher; ii. 266.

Digestive organs; i. 50.

Dodo; ii. 118.

Dormancy of birds considered; ii. 40.

Duck's bill described; i. 33.

- occasional long flights of; i. 92.

Chinese, management of; ii. 189.

affection of; ii. 194.

- nest of Wild; ii. 191.

- Eider, how to obtain the down; ii. 195.

- Indian mode of catching; ii. 197.

Shooters, adventures of ; ii. 199.

\section{Mexican; ii. 204.}

decoy; ii. 205.

Eagles, various particulars respecting them; i. 112.

- carrying off Children; i. 116.

Egg of the Cuckoo, why laid in small birds' nests; ii. 78.

Emu; ii. 116.

Eye, insect flying in the; ii. 49.

- Herons and Bitterns, dangerous to the; ii. 143.

Falcon, Iceland, valuable; i. 146.

Falconry; i. 150.

Familiarity of Crows, anecdote of ; i. 233.

Fasting powers of birds; i. 62.

Fatal event to a family of Sea-fowlers; ii. 267.

Feathers of Eagles prized; i. 134.

- rapid growth of; ii. 20.

Feats of Bird-catchers; ii. 264.

Feeding, mode of, Thrushes; i. 205. 
Feeding-box for Pheasants; ii. 98.

Finches, family of; ii. 9.

Flamingo, or Phœnicopterus; ii. 145.

singularity of its bill; ii. 146 .

numerous on the Coast of Africa; ii. 149.

Flight, difficulties connected with; i. 3.

- of birds; i. 84, 92.

Fly-catchers; i. 208.

Food consumed by small birds; ii. 26 .

Fowl, singular contents of the stomach of a; i. 60 .

Frigate-Bird lives almost on wing; i. 96.

Frost favourable to insects; i. 243.

Frozen, birds occasionally; i. 164.

Gallinaceous, Poultry; ii. 84.

Gallinula, Water-Hen; ii. 119.

Gannet, use of its horny mask; i. 64.

- nests; ii. 219.

Gastric juice; i. 55.

Geese, rearing of, profitable; ii. 170.

- management of them in Lincolnshire; ii. 171. - sacred among the ancients; ii. 172.

instances of attachment in; ii. 173.

various anecdotes of; ii. 178.

Barnacle, or Tree; ii. 182.

Gigantic Crane, or Hurgila; ii. 140.

Gizzard, functions of the; i. 58, 60.

Goat-Sucker, bill of the; i. 36.

Goldfinches, anecdote of; ii. 10.

- sagacity of; ii. 11.

sociability of; ii. 13.

Grackles; i. 212.

Grebe, crested; ii. 245.

shot at Adlington, Cheshire; ii. 246.

Guillemots; ii. 247.

Gulls feeding on herrings; ii. 227.

- anecdote of a pair; ii. 229.

Gullet; i. 54. 
Hare and Hawk, contest between; i. 162.

Hawk tribe; i. 112, 143.

Hawking; i. 150.

Hawks rearing Chickens; i. 170.

- why respected by Turks; i. 171.

Hen kills mice; ii. 95.

- swimming; ii. 95 .

Herons taken by Hawking; i. 155.

- legs allure fish; ii. 132.

- feathers; ii. 133.

- voracity of; ii. 133.

Honey-Buzzard feeds on wasps; i. 168.

Hoopoe; ii. 67, 69 .

Hornbills, bills of; i. 38.

general character; i. 211.

Homed Screamer, Palamadea cornuta; ii. 129.

Hospital for Cranes and Storks; ii. 136.

Humming-Birds; ii. 67, 71.

Hurgila, or Gigantic Crane; ii. 140.

Ibis, Sacred; ii. 166.

Imitative power of birds; i. 68.

Injuries from Crows and Rooks; i. 239.

- and benefits of small birds; ii. 25.

Insects, quantity devoured by Swallows; ii. 48.

Jabiru; ii. 142.

Jacamars; ii. 75.

Jacana walks on water-plants; ii. 127.

Jackdaws; i. 247.

Jays, partial migration of; i. 101.

- killed by Hawks; i. 163.

- general character; i. 250.

Kingfisher; ii. 70.

Language of birds; i. 73.

Lapwing, food of the; ii. 154.

Larks; ii. 28.

Latirostres-flat beaked; ii. 144.

VOL. II. 
Leg-bones; i. 45.

Legs of Herons allure fish; ii. 132.

Levirostral-light-billed; ii. 83.

Light on American Bittern's breast; ii. 133.

Linnets' affection for their young; ii, 24.

Magpies; i. 250.

$$
\text { nurse young Ravens; i. } 264 .
$$

Manikins; ii. 28.

Mate, birds choose new ones when the old ones die; ii. 54, 220.

Meetings of Crows and other birds; i. 234.

Mice killed by a Hen; ii. 95.

Migration of Cuckoos; ii. 75, 77.

- Storks and Cranes; ii. 134.

Swallows; ii. 45.

Mocking-Bird; i. 69.

Muscular power of the wing of a bird; i. 85 .

Music attracts Nightingales; ii. 38.

Narrow-beaked, Pressirostral; ;ii. 119.

Nest, Blackbiri's, by a rabbit's seat; i. 206.

- Eagles; i. 125.

_ curious one of African Finches; ii. 12.

- eatable; ii. 55 .

- rapidity of building; ii. 12 .

- of Titmouse, singular place for one; ii. 29.

- Sparrows and Redbreast; ii. 19, 32.

- curious, of a Thrush; i. 203.

- Swallow, in a bell; ii. 51 .

- not always of mud; ii. $\mathbf{5 5}$.

- Pigeons; ii. 91.

— Ostrich; ii. 113.

Water-Hen; ii. 123, 125.

Nightingales, migration of; ii. 36 .

Night, birds sing during; ii. 38.

Nuthatch, Sitta Europea; ii. 67.

Oil on feathers, use of; i. 80.

Oriole, Golden; ii. 1. 
Ostrich, substance found in the stomach of one; i. 53.

- affectionate disposition of the; ii. 114.

Owls, particulars respecting; i. 173.

Oyster-Catchers; i. 225; ii. 130;

Palamedea Cornuta, or Horned Screamer; ii. 129.

Palmipedes, web-footed; ii. 169.

Park, Mungo, anecdote of; i. 2.

Parrots; ii. 83.

\section{- beak described; i. 31.}

Partridge and Turkey associate; ii. 103.

- tame; ii. 105.

how taken in the East; ii. 108.

Passerine order; ii. 1.

Peacocks formerly prized as dainties; ii. $\mathbf{9 9 .}$

Pelican's beak; i. 38.

traditions of ; ii. 208.

Penguin's selection for breeding-place; ii. 257.

trade in the Shetland Islands; ii. 259.

Petrel, used as a candle; ii. 239.

- Stormy, sailor's superstition of ; ii. 241.

—_ found inland; ii. 241.

Pheasant attacks a lady; ii. 93.

directions for rearing them; ii. 97.

Pigeons, living peaceably with a Hawk; i. 169.

- Passenger; ii. 85.

Wood; ii. 89.

's nest by a litter of kittens; ii. 92.

Platypus, Duck-billed; i. 35.

Philoris Paradiseus, plumage of ; i. 77.

Plover, Stilted; i. 48.

- Egyptian, anecdote of an; ii. 155.

Plumage of birds considered; i. 77, 81, 82.

Pouch of the Hurgila, use of; ii. 140.

Bustard; ii. 112.

Poultry tribe; ii. 84.

Pressirostral, or Narrow-beaked; ii, 119. 
Puff-backed Shrike; i. 201.

Puffin and Raven; i. 225.

— or Sea-Parrot; ii. 248.

- how caught; ii. 248.

Quails; ii. 109.

Rails; ii. 129.

Rain, why Swallows fly low during; ii. 50.

Rapacious birds; i. 112.

Rapidity of flight; i. 88, 90.

Raven, notices of the; i. 220, 226.

- and Puffin; i. 225.

Razor-bill chased by a Hawk; ii. 251.

Rearing Pheasants; ii. 97.

Redbreast builds in a dining-room curtain ; ii. 32 . in a school-house; ii. 33. in a church; ii. 34.

Red-legged Crow; i. 247.

Redpole and Goldfinch; ii. 10.

Redstart's nest in the hinge of a door; ii. 30 .

Ring-Dotterel; ii. 152.

Rooks; i. 231.

Rookeries; i. 245.

Ropes of hide used in St. Kilda; ii. 261.

Sacred Ibis; ii. 166.

Sandpipers on the sea-shore; ii. 151.

Screamer, Horned, Palamadea; ii. 128.

Sea-birds feeding on fish; ii. 211. found far out at sea; i. 94.

Swallow, or Tern; ii. 223.

Sitta Europea, Nuthatch ; ii. 68.

Sheldrake builds in rabbit-holes; ii. 193.

Shoveller Duck's bill; i. 34.

of New Holland; i. 35.

Shrike, or Butcher-bird; i. 189.

used for hawking; i. 199.

Skeleton of a bird; i. 29, 42 . 
Skimmer (Rhynchops); ii. 222.

Snake-eater, Vultur serpentarius; i. 141.

Snipe's attachment to place; ii. 158.

- mode of feeding; i. 33.

Snowy Owl, habits of the; i. 178, 182.

Song in birds pleasurable; i. 75.

South Stack, punctual return of sea-birds to the; i. 109.

Spider, height to which they ascend in the air; ii. 50.

Sparrow, boldness of ; ii. 18.

- sociability of ; ii. 21.

- affection for their young; ii. 22.

- singular death of a; ii. 23.

- nest in a church; ii. 35.

Hawk, mode of catching; i. 161.

Spoon-bill shot at Holyhead; ii. 145.

's beak; i. 39.

Stanley Crest explained; i. 119.

Starlings, habits of ; ii. 2.

Stomach, Heron's; ii. 132.

Stork; ii. 131.

- kills its faithless mate; ii. 139.

Strength of the Condor; i. 138.

birds and bones; i. 40.

Swallow's bill; i. 36 .

- singular nest; i. 108.

occasionally detained; i. 110.

different species; ii. 40.

if ever found dormant; ii. 41, 45.

quantity of insects eat by; ii. 48.

- nest in a bell,-in a lamp; ii. 51 .

courage; ii. 52.

- suit their nests to circumstances; ii. 55.

- nests eatable; ii. $\mathbf{5 5}$.

scarcity of them in late years; ii. 61 .

Swan, strength of; ii. 185.

Swiftness of Ostriches; ii. 114. 
Swiftness of flight, how calculated; i. 88.

Swimming Hen; ii. 95.

Tables of Classification; i. 8.

- utility of them; i. 25.

Tame Partridge; ii. 105.

Woodpecker; ii. 81.

Hawks; i. 168.

Tanagers; i. 210.

Tantalus Ibis; ii. 144.

Tenuirostral tribes, of Passerine order; ii. 67.

Teneurostres, or Slender-billed, of order of Waders; ii. 149.

Tern, habits of the; ii. 224.

Thrush tribe; i. 202.

Titmouse found at sea; i. 94 .

Todus viridis; ii. 67 .

Tongue of the Wryneck; ii. 81.

Toucan-bill; i. 37.

- mode of killing small birds; i. 37.

- singular position while asleep; i. 43. ; ii. 83.

Tracheas, or windpipes, of Duck tribe; i. 68.

Traps for Eagles; i. 132.

Kestrels; i. 160.

Traps for Sparrow-Hawks; i. 161.

Tropic Bird lives almost always on wing; i. 95.

Turkey, Wild, anecdote of the; ii. 102.

__ and Partridge associate; ii. 103.

__ Cock rearing young ones; ii. 104.

Turks, veneration for Storks; ii. 137.

Turtles, migration of; i. 103.

Voice of birds; i. $67,76$.

Voracity of some birds; i. 52.

Vulture floating on a corpse; i. 124.

voracity; i. 137.

- particulars of ; i. 135.

Wagtail's nest in a boat; ii. 30 . in a brass foundry; ii. 30 . 
Warblers; ii. 28.

Warmth of birds; i. 66.

Water-Crow walking under water; i. 87.

Hen, account of ; ii. 124.

Washington, bird of ; i. 128.

Wedge-billed birds, or Cuneirostral; ii. 74.

Weight, comparative, of birds; i. 86.

Windows, how to prevent Swallows building near; ii. 60 .

Wing-bones described; i. 45.

Winter, hard, favourable to insects; i. 243.

Wire-worms destroyed by Rooks; i. 242.

Woodcocks breed in Scotland; ii. 159. migration of ; ii. 160.

rapid flight proved; ii. 163.

- method of catching them; ii. 163.

- supposed to remove their young; ii. 159.

Wood-Pigeon; ii. 89.

Woodpecker; ii. 74.

\section{tame; ii. 80.}

Wryneck, tongue of the; ii. 74, 81 .

THE END. 

[LIST No. 2.]

\section{INSTRUCTIVE AND ENTERTAINING WORKS, \\ FOR YOUNG PERSONS;}

PUBLISHED BY

JOHN W. PARKER, WEST STRAND, LONDON.

Those to which a * is prefixed, are published under the Direction of the Committee of General Literature and Education, and are upon the Second Supplemental List of the Society for Promoting Christian Knowledge.

Speedily will be published, Volume I., (to be completed in Three Volumes,) of

THE FAMILY HISTORY of ENGLAND; accompanied by upwards of One Hundred ENGravings of Costumes, Architecture, Manners and Customs, Arms, Implements, Coins, \&c., drawn from the best Authorities, and forming the most complete Pictorial Accompaniment to English History ever published.

THE main purpose of the FAMrLY HrsTORY of ENGLAND has been to unite objects which in such undertakings are not always found to coincide; namely, to render the study of English History not merely instructive, but interesting and amusing. For this purpose, the greatest care has been taken to seize upon all those striking features in the detail of events, which not only convey to the mind of the reader a vivid picture of scenes past, but induce him to argue from effects to their causes. While the philosophy of history, therefore, is sedulously taught, it is tanght in a manner calculated to gratify both young and old, by affording to the one class ample scope for reflection; to the other, matter that stirs and excites, while it conveys sound moral instruc. tion.
In perfect agreement with this plan for the work itself, is that by which the selection of the ILLUSTRATIONS has been regulated. Neither expense nor labour has been spared in collecting, from every authentic source, the most correct delineations of the Dresses, Architecture, Manners and Customs, Implements, \&c., of the successive periods of English History; and as those appended to each chapter will be found to bear upon the facts referred to in the text, the reader, and especially the young reader, will derive from them the greatest assistance.

The Family History of England is addressed to readers of all ranks and ages. It is eminently adapted for the use of Schools, and will be found not unworthy of perusal by persons more advanced in historical information. 


\section{TALES AND STORIES FROM HISTORY. By AGNES STRICKLAND. Two Volumes, with many Engravings.}

THE object of these Tales is to impart at once instruction and amusement to the youthful mind. Each of these stories is either founded upon, or con nected with, some important event in History, and furnishes useful and entertaining information as to the Manners and Customs of the peculiar era to which it relates. This is conveyed in language sufficiently simple to be adapted to the comprehension of children at a very early age; but, at the same time, it is hoped that the Tales will be found interesting to readers at a much more advancerd period of life.

These Tales are by no means intended to supply the place of History. They are, on the contrary, calculated to create a taste for that style of reading, by indulging the juvenile reader with an attractive portion of its choicest flowers, arranged in the tempting form of Stories. In addition to this, every Tale is rendered the vehicle for introducing some moral lesson, calculated to improve the heart, and to impress the tender mind of Childhood with a love of virtue.

Such heing the object of these Tales, it is to be hoped that they will be found not only essentially useful, but sufficiently attractive, to the young, as to supersede the use of many of the silly and pernicious fictions which have hitherto, unfortunately, constituted too large a proportion of the books provided for the use of young people.

* A FAMILIAR HISTORY of BIRDS: their Nature, Habits, and Instincts. By the Rev. EDWARD STANLEY, M.A., F. L. S., Rector of Alderley, Cheshire. Two Volumes, with many Engravings.

THIs work is intended for a class of readers to whom mere scientific details would be unacceptable, if not unintelligible. Such therefore have been, as much as possible, avoided, and only alluded to as inducements to those who are interested in the subject, to make further progress in so attractive a department of Natural History.

There are few individuals who have it not in their power, occasionally, to remark the instincts and habits of

Birds; and the many anecdotes collected from the Author's own observa. tion, the information of friends, or various respectable sources, will, it is hoped, excite others to register any facts within their reach, which may illustrate the mysterious economy whereby this beautiful portion of God's creation is enabled, in so many instances, to surpass the highest efforts of man's ingenuity, foresight, or philosophy.

\section{WILD ANIMALS. By MARY ROBERTS. Printed} Uniformly with " Domesticated Animals, considered with reference to Civilization and the Arts." By the same Writer.

\section{* DOMESTICATED ANIMALS considered with reference}

to Civilization and the Arts. 3s. $6 d$.

Thrs work will comprise a general sur- are rendered habitable only by the subvey of Domestic Quadrupeds, and the jugation and appropriation of certain purposes they subserve in the great species, are generally described, with economy of nature: their connexion, too, with the progress of civilization and the arts, with the history of nations, and the peculiarities of soil and climate, are also specified; those countries which the manners and habits of the natires, as far as they are associated with the history of Domestic Animals.-Introduction. 


\section{FABLES, EMBLEMS, and MORAL MAXIMS, in PROSE and VERSE. Selected by ANNE PARKER. In a small Volume, with One Hundred Wood-Cuts.}

Wirhour insisting upon the value of Fables as a medium of instruction, the fascination of them to young people cannot be denied. It does, however, singularly happen, that, of the numerous collections of Fables which have, from time to time, been published, a large majority, and more particularly those which are known as the School Edition of AEsop's and of GAY'S FabLES, abound in subjects and expressions, not only repulsive from their coarseness, but more gravely objectionable from their anti-social, and, frequently, im. moral tendency.

These objections will not be found applicable to the Collection now offered to the public; for it is hoped and trusted, that not a line has been admitted which the most scrupulous parent would desire to withhold. The best Collections have been consulted, and most of the favourite old Fables are retained; but, in accordance with the plan of the work, the liberty of altering objectionable passages has been freely exercised. Many pieces have been introduced from sources not usually accessible, and several original compositions and translations have also been given. In addition to these, a copious selection of Emblems and Moral Maxims has been made from a translation of KRAMAGHER's beautiful little Volume of Parables, and from the "Economy of Human Life."

\section{* CONVERSATIONS of a FATHER with his CHIL- DREN. Two volumes, $5 s .6 d$.}

THEsE Conversations were first written with a view to the gratification and improvement of the Author's children. They are now published with the sincere desire that the perusal of them may afford to others also somewhat of pleasure and advantage. The prineiples liere inculcated are those of the Religion of the Gospel. The little work is intended to promote cheerful and fervent piety, a contented, obedient, and grateful frame of mind, feelings of affec- tion and kindness towards our friends, and of active benevolence towards all. The habit, too, of deriving instruction and delight from contemplating the varied scenes of nature, and the ordinary occurrences of life, it is hoped may, at the same time, be instilled and cherished; whilst the maxim, the spirit of which the Author trusts will be found to breathe through the whole, is BE GOOD AND BE HAPPY.

\section{* SISTER MARY'S TALES in NATURAL HISTORY. $2 s .6 d$.}

IN drawing up these tales for children at an early age, the writer has, aimed rather at correctness than at variety of information, or originality of matter. She has endeavoured to interest her young readers, yet she has been very careful not to mislead them by exaggerated statements, and has thought it best to leave for after-years, and for graver works, much that is undoubtedly

curious, and deserving of their inquiry : satisfied if she has in any degree succeeded in awakening the spirit of that inquiry, and, still more, if she has directed the infant mind to seek for those proofs of Divine wisdom, power, and goodness, in the formation and habits of these various beings, which at a mature age will assuredly reward the study of the naturalist. 


\section{INSTRUCTIVE AND ENTERTAINING WORKS.}

\section{* SCENES and SKETCHES from ENGLISH HISTORY. With ENGRAVINGs. 3s. $6 d$.}

IT is our purpose to narrate the prin. for a considerable period on that of cipal and most interesting events in the annals of England; not to reject any topic connected with them which is likely to entertain and instruct: Religion, Literature, Customs, and Manners; to avail ourselves of authentic private memoirs and anecdotes of celebrated personages; sometimes to com. prise the history of many years in a brief passing notice; at others, to dwell

a few weeks, or even of a single day: Rejecting, in short, all the trammels of the regular historian, and rejoicing in the liberty of our own far humbler literary station, we do not intend to impose any restraints upon our wanderings, save those of strict chronological arrangement, and an undeviating adherence to guides of acknowledged autho. rity.-Introduction.

\section{CONVERSATIONS on GARDENING and NATURAL HISTORY. By the AUTHOR of the ELEMENTS of BO- TANY. 2s. 6d.}

To render that most rational and innocent of occupations attractive to young persons, by divesting it of its technical details, and its practical difficulties, is the object of this publication. The form af Conversations is assumed, as more agreeable than didactic precepts; and incidental observations on Natural His. tory are interspersed, to vary the sub. ject, and to lead the young reader to habits of observation and reflection on the Wonders of Creation.

\section{* READINGS in BIOGRAPHY. A Selection of the Lives of the most Eminent Men of all Nations. 4s. $6 d$.}

TuE design of this work is to give an the lives have been compiled from account of the lives of the leaders in original sources; those of the Oriental the most important revolutions which history records, from the age of Sesos. tris to that of Napoleon. Care has been taken to select those personages, eoncerning whom information is most required by the historical student. All

Sovereigns, especially, are taken from Oriental writers; and 11 the life of Saint Louis are some curious particulars of the Egyptian Crusade from contem. porary A rabic Historians.

\section{* READINGS in ENGLISH PROSE LITERATURE;} containing choice Specimens of the Works of the best English Writers, from LoRD BAcon to the present time. With an INTronuctory Essay on the Progress of English Literature. $4 s .6 d$.

Trrs volume is intended to furnish the general reader with some valuable specimens of English prose composition. They are taken from the works of those writers who have chiefly determined the style of our prose literature, and not. only in themselves instructive and entertaining, but are also of sufficient variety, and of ample length, to render the reader familiar with the beauties and the peculiarities of the various writers. Biographical sketches of the authors, and notices of the times wherein they flourished, are also introduced, and upon the whole, it is hoped, that the volume will be found a useful introduction to the systematic study of our na. tional literature. 
* LIVES of SACRED POETS. Containing Introductory Sketch of Sacred Poetry. George Wither, Francis Quarles, Giles Fletcher, George Herbert, Richard Crashaw. By R. A. WILLMOTT, Esq., Trinity College Cambridge. 4s. $6 d$.

THE writer of these Lives has endeavoured to presint as ample a view as the limits of a volume would permit, of the state of Sacred Poetry in the reigns of Elizabeth, James the First, and Charles the First. Among the poets and distinguished individuals, of whom Biographical and Critical Sketches are given, may be enumerated R. Southwell; $\mathbf{H}$. Constable; B. Barnes; Francis Davison, the author of some exquisite Versions from the Psalms ; Donne; W. Browne, the sweetest disciple of Spenser's Pas- toral School ; Sir John Denham ; Heywood, the author of the Hierarchie of the Blessed Angels; G. Sandys; Lord Bacon, the friend of Herbert; Hobbes, the philosopher, and Ben Jonson, his associate in the translation of the $A d$ vancement of Learning; the celebrated Lord Herbert, of Cherbury; the accomplished and learned Selden; Archbishops Williams and Laud; Lord Pem. broke, the lover and loved of poets; Cowley, the affectionate friend of Crashaw, \&c.

\section{* LIVES of EMINENT CHRISTIANS. By the Rev.} R. B. HONE, M.A., Curate of Portsmouth. Two vols. 9s.

Tue paths of good men are commonly so full of peace, and the sorrows which befall them, so mercifully softened and blessed by a sacred influence, that few more pleasing or successful ways of re. commending the fear and love of God have been found, than the publication of religious biography.

Contents: The Lives of Bishop Wilson; Archishop Usmer ; Dr. Hammond; John Evelyn; Bernard Gilpin; Philip de Mornay; Bishop Bedell; and Dr. Horneck.

\section{LIGHT IN DARKNESS; or, the RECORDS of a VII- LAGE RECTORY. 3s. $6 d$.}

Happy the man that sees a God employed

In all the good and ill that chequer life.-Cowper.

Contents. Introductory Chapter; The Village.-The Retired Tradesman.-The Good Aunt.-The Family at the Hall.- The Village Schoolmaster.-The Village Apothecary.-The Deserted Wife.

\section{* READINGS in POETRY. A Selection from the Works of the best English Poets, from Spenser to the present times; and Specimens of the American Poets. With Literary Notices of the Writers, and brief explanatory Notes. $4 s .6 d$.}

CARE has been taken to select such pieces and passages as best illustrate the style of the respective Authors, and are, at the same time, not beyond the average capacity of youthful students. It is scarcely necessary to add, that the most scrupulous attention has been paid to the moral character of the extracts. 


\section{SADOC AND MIRIAM. A Jewish Tale of the Time of Our Saviour. $1 s .8 d$.}

THE chief object of the Author has been to exhibit the Evidences of Christianity as they must have appeared to a Jew, in our Saviour's time. In order that this might be clearly done, it was necessary to point out the prevailing prejudices to which they were opposed. The introduction of these into a story seemed

more likely to attract the reader, than if they liad been barely exhibited to his view through the medium of an argumentative treatise; while such combination enabled the writer to intermix some portion of Jewish antiquities.Introduction.

\section{LE BOUQUET LITTERAIRE. Recueil de Beautés Re-} ligieuses et Morales, de divers Auteurs. Par Feu L. T. VENTOUILLAC. Professeur de Littérature Française au Collège Royal à Londres. $3 s .6 d$.

Trrs little posthumous volume is the production of an individual, whose living energies were consecrated to the important work of Education, and who, early in life, fell a martyr to his exertions in that cause, at a period when the fairest prospects of present usefulness and of finture eminence were opening before him.

* READINGS in SCIENCE; being EXPLANATIONS of some of the most interesting APPEARANCES and PRINCIPLES in NATURAL PHILOSOPHY, expressed in simple Language, and illustrated by familiar Examples. 5 .

THrs volume differs materially from / in the manner in which they are treated, previous publications having the same in the examples by which principles object, namely, that of rendering the are illustrated, and in certain reflections path of science easy and iuviting to and remarks, not generally introduced beginners. The chief differences will into scientific writings.

be found, in the order of the subjects,

* MECHANICS APPLIED TO THE ARTS; including STATICS and HYDROSTATICS. By the Rev. H. MOSELEY, M.A., Professor of Natural Philosophy and Astronomy, King's College, London. $6 s .6 d$.

THrs work contains treatises on the sciences of Statics and Hydrostatics, comprising the whole theory of Equilibrium. It is the first volume of a course of Natural Philosophy, intended for the use of those who have no knowledge of Mathematics, or who have made but little progress in their mathematical reading. Throughout the whole, an attempt has been made to bring the principles of exact science to bear upon questiuns of practical application in the arts, and to place the discussion of them within the reach of the more in. telligent of that useful class of men, who are connected with the manufactures of the country. 
POPULAR PHYSIOLOGY ; being a familiar Explanation of the most Interesting Facts connected with the Structure and Functions of Animals, and particularly of Man; adapted for general Readers. By PERCEVAL B. LORD, M.B., M.R.C.S.

Of the Bombay Medical Establishment. 7s. 6d.

To trace the finger of God in the works : organs, all performing different offices, of creation, to consider " the wonders that he doeth amongst the children of men," has ever been a source of the purest and noblest gratification. This volume, taking for its subject the animal body, and more peculiarly that of man, explains the various contrivances by which he is enabled to "live, move, and have his being." shows him destined to maintain relations, prin. first as consisting of numerous sets of $\mid$ of sense.

* THREE WEEKS in PALESTINE and LEBANON. With many ENGRAvings. 3s.

* THE CRUSADERS, or SCENES, EVENTS, and CHAracters, from the TIMES of the CRUSADES. By THOMAS KEIGHTLEY, Esq. Two volumes, $11 s$.

* THE HISTORY of MOHAMMEDANISM, and the principal MOHAMMEDAN SECTS, derived chiefly from Oriental Authorities. By W. C. TAYLOR, B.A., T.C.D. 5s. $6 d$.

\section{LORD TEIGNMOUTH'S LIFE of SIR WILLIAM} JONES ; with Selections from his Works, and a LIFE of LORD TEIGNMOUTH. By the Rev.SAMUEL CHARLES WILKS, M.A. Two volumes, $10 s .6 d$.

ROSE-BUDS RESCUED, and presented to my CHILDREN. By the Rev. SAMUEL CHARLES WILKS, M.A. 4s. $6 d$.

The BRItish MONThs, a Poem, in Twelve Parts. By RICHARD MANT, D.D., M.R.I.A., LoRd Bishop of Down and Connor. Two volumes, $9 s$.

SACRED MINSTRELSY; a COLLECTION of the FINEST SACRED MUSIC, by the best Masters, arranged as Solos, Duets, Trios, \&c., and Chorusses; and with Accompaniments for the Piano-Forte or Organ. Completed in two handsome folio volumes, price $21 s$, each; or in Nos. I. to XXIV., price $1 s .6 d$. each. 


\title{
The GERMAN WORKS of ADOLPHUS BERNAYS,
}

\author{
Pн. Dr. \\ German Professor in King's College, London.
}

\section{GERMAN HISTORICAL ANTHOLOGY. $7 s$.}

It cannot be disputed that the works / this selection from the German Hisused by a student in acquiring his first torians, a class of writers that has lately knowledge of a language, should con- become as numerous as it is distintain matter calculated to enlarge his guished.

mind. With this view, I have made

A COMPENDIOUS GERMAN GRAMMAR. Second Edit. $5 s$.

THE great merits of this Grammar are perspicuity combined with conciseness. The rules, although evidently the result of original inquiry, are stated in few words, unencumbered by philo-

sophical disquisitions, but as often as necessary compared with the principles which yovern the English Language, and illustrated by striking examples taken from the best German writers.

FAMILIAR GERMAN EXERCISES, adapted to the German Grammar; with Notes; and Specimens of German Handwriting. 6 s. Most of the examples given in these / easy gradation, the principles which Exercises are taken from the standard govern the formation of German periods. German writers. In the whole of the etymological part they are simple and short, so as to show at the first glance their bearing upon the rules they are intended to illustrate. Those on the Syntax and Construction display, in an

The book is chiefly intended to teach the writing, but it will be found equally serviceable as a key to the German writers. The Lists and Notes are of the greatest practical utility.

GERMAN EXAMPLES, illustrating the Author's German Grammar, and forming a KEY to the Familiar German Exercises. 3s.

THis book, as may be seen by the title, either when the Student is deprived of may be used as reading lessons, explanatory of the rules of the Grammar; or as a Key by which to correct the Exercises, the advantages of a Teacher, or when it is wished to employ the hours of instruction to other purposes.

The GERMAN READER, a Selection from the most Popular Writers, with Translations and Notes, for the Use of Beginners. $5 s$.

GERMAN POETICAL ANTHOLOGY, or Select Pieces from the principal German Poets; with a History of German Poetry, and Explanatory Notes. Second Edition. 8s. $6 d$.

IN these reading-books, of which the $\mid$ The examples are, at the same time, Reader should be used first, nearly all either amusing or instructive, and so the difficulties which can occur in selected as to suit both sexes of every reading German have been solved. age.

London: JOHN W. PARKER, Publisher, West Strand. 








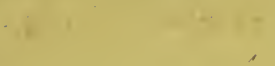

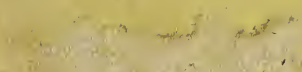

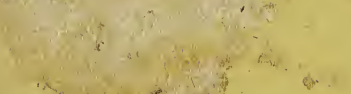

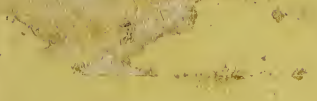

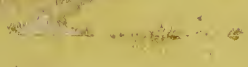
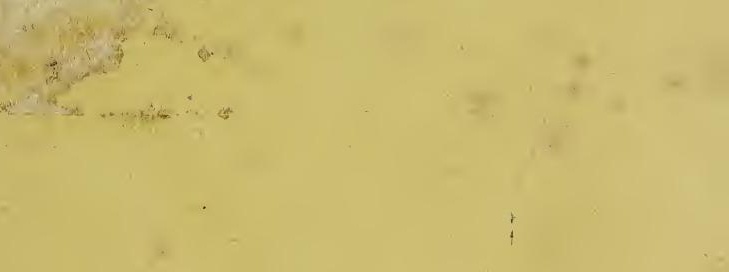

1

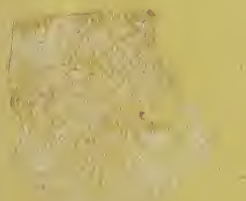


